\title{
Microlicia D. Don (Microlicieae, Melastomataceae) no Parque Nacional da Chapada dos Veadeiros, Estado de Goiás, Brasil ${ }^{1}$
}

\author{
- Danielle de Oliveira Diniz ${ }^{2,3}$ e $\odot$ Marcos José da Silva $^{2}$
}

Recebido: 30 março 2019; aceito: 5 dezembro 2019

Como citar: Diniz, D.O. \& Silva, M.J. 2020. Microlicia D. Don (Microlicieae, Melastomataceae) no Parque Nacional da Chapada dos Veadeiros, Estado de Goiás, Brasil. Hoehnea 47: e322019. http://dx.doi.org/10.1590/2236-8906-32/2019.

ABSTRACT - (Microlicia D. Don (Microlicieae, Melastomataceae) in the Chapada dos Veadeiros National Park, Goiás State, Brazil). Microlicia D. Don comprises 170 species, of which 150 occur in Brazil, being 149 endemic. The taxonomic knowledge about this genus in the Brazilian Midwest region is insufficient. For this reason, the taxonomic treatment of Microlicia in the Chapada dos Veadeiros National Park, in Goiás State, Brazil, is presented. The collections were conducted for 24 months between 2014 and 2016, and the expeditions lasted from three to five days each. Eighteen species were recorded, four of which described during this study (M. chrysoglandulosa R. Romero, Versiane, Fontelas \& D.O. Diniz-Neres, $M$. veadeirana D.O. Diniz-Neres \& M. J. Silva, M. latifolia D.O. Diniz \& M.J. Silva and M. stenodonoides D.O. Diniz-Neres \& M.J. Silva). Microlicia scoparia DC. was recorded for the first time from the Goiás State. Microlicia crebropunctata Pilg. and M. melanostagma Pilg. are considered rare species. The other species were considered common in the states of Goiás and Minas Gerais. It is provided an identification key, descriptions, comments on distribution, phenology and morphological relationships, as well as illustrations and photographs for most of the recorded species. With this study, the number of species recorded for the state of Goiás rises from 19 to 24.

Keywords: Cerrado mountain areas, diversity, endemism, Myrtales, taxonomy

RESUMO - (Microlicia D. Don (Microlicieae, Melastomataceae) no Parque Nacional da Chapada dos Veadeiros, Estado de Goiás, Brasil). Microlicia D. Don compreende 170 espécies, 150 das quais presentes no Brasil, sendo 149 delas endêmicas. O conhecimento taxonômico desse gênero na região Centro-Oeste do país é precário. É apresentado o tratamento taxonômico de Microlicia no Parque Nacional da Chapada dos Veadeiros, Goiás, Brasil, o qual resultou de 24 coletas mensais com duração de três a cinco dias durante o período de 2014 a 2016. Foram registradas 18 espécies, sendo quatro estabelecidas durante os estudos desse grupo de pesquisa e já publicadas (M. chrysoglandulosa R. Romero, Versiane, Fontelas \& D.O. Diniz-Neres, M. veadeirana D.O. Diniz-Neres \& M. J. Silva, M. latifolia D.O. Diniz \& M.J. Silva e M. stenodonoides D.O. Diniz-Neres \& M.J. Silva), uma nova ocorrência para Goiás (M. scoparia DC.), duas espécies (M. crebropunctata Pilg. e M. melanostagma Pilg.) são consideradas raras, e as demais comuns aos Estados de Goiás e Minas Gerais. São apresentadas chave de identificação, descrições com comentários sobre distribuição, épocas de floração e frutificação, comparações morfológicas, ilustrações para os táxons, bem como fotografias para a maioria deles. A partir deste estudo o gênero passa de 19 para 24 espécies no Estado de Goiás.

Palavras-chave: áreas montanas do cerrado, diversidade, endemismo, Myrtales, taxonomia

\section{Introdução}

Melastomataceae é uma das maiores famílias de Myrtales com 170 gêneros e 5105 espécies distribuídas nos trópicos (Clausing \& Renner 2001, Stevens 2016), dos quais 73 e 1430 , respectivamente, ocorrem no
Brasil (Flora do Brasil 2020), e compreende duas subfamílias Olisbeoideae Burnett e Melastomatoideae Seringe, (Stevens 2016). A família é monofilética (Renner 1993, Clausing \& Renner 2001), circunscreve dez tribos (Penneys et al. 2010, Goldenberg et al. 2015). Apesar de bastante estudada no Brasil,

1. Parte da Dissertação de Mestrado da primeira Autora

2. Universidade Federal de Goiás, Instituto de Ciências Biológicas, Departamento de Botânica, Avenida Esperança s/n, Campus Samambaia, 74001-970 Goiânia, GO, Brasil

3. Autor para correspondência: danidiniz26@gmail.com 
conforme destacaram Goldenberg et al. (2012), a família ainda carece de estudos. Fica muito evidente quando se compara a riqueza de espécies e a carência de taxonomistas em regiões de grande extensão do país, como o Centro-Oeste e Norte.

Microlicieae com 250 espécies é uma das tribos de Melastomataceae com distribuição essencialmente neotropical e tem no Brasil seu centro de diversidade com 206 espécies, 194 delas endêmicas (Flora do Brasil 2020). Circunscreve os gêneros Trembleya DC., Chaetostoma DC., Lavoisiera DC., Rhynchanthera DC., Stenodon Naudin, Poteranthera Bongard e Microlicia D. Don, os quais podem ser reconhecidos pelo ovário com ápice glabro, androceu com estames usualmente dimórficos, anteras rostradas com conectivos prolongados e apêndices ventrais, frutos capsulares e sementes com testa foveolada ou lacunoso-reticulada (Fritsch et al. 2004, Rocha et al. 2016).

Microlicieae foi estabelecida por Triana (1871) e teve sua circunscrição modificada por Cogniaux (1891), Renner (1993), Almeda \& Martins (2001), Fritsch et al. (2004) e mais recentemente por Rocha et al. (2016) que lhe subordinaram os gêneros do paragráfo acima.

Microlicia é o mais diverso gênero de Microlicieae com 170 espécies (Wurdack 1993), 151 das quais presentes no Brasil, sendo 149 delas endêmicas, sobretudo, dos campos rupestres ou úmidos da Cadeia do Espinhaço dos Estados de Minas Gerais e Bahia (BFG 2015, Flora do Brasil 2020). Este gênero foi estabelecido por David Don em 1823 e trabalhado taxonomicamente principalmente por Cogniaux (1891) que lhe atribuiu 95 espécies acomodadas em três seções (Chaetostomoides (Naudin) Cogn., Pseudomicrolicia Cogn. e Microlicia) com base principalmente em características do hipanto e do cálice, tais como, forma, tamanho de suas lacínias em relação ao tubo do cálice e ainda presença de indumento. Destas, apenas Microlicia sect. Chaestostomoides foi revisada por Romero (2003) que resumiu sua circunscrição a $M$. viminalis (DC.) Triana.

Microlicia, diferencia-se dos seus demais cotribais e é reconhecido pela combinação do hábito predominantemente subarbustivo com caules ramificados em um padrão corimbiforme, folhas imbricadas ou não, (1) 3,5, ou 7-nervadas, com formas e consistências variadas e com ou sem glândulas circulares, flores usualmente solitárias ou em tríade com pétalas rosa magenta, estames conspicuamente dimórficos ou subisomórficos e ovário em geral 3 ou 5-locular. Dos seus cotribais, Trembleya é o que mais a ele se assemelha morfologicamente, porém, representantes de Microlicia são plantas usualmente subarbustivas ( $v s$. plantas usualmente arbustivas ou arbóreas em Trembleya); possuem folhas com nervuras discretas e usualmente imbricadas no caule (vs. folhas com nervuras evidentes, decussadas ou ascendentes); flores solitárias, ou em tríade, em um aspecto dicasial, mas sem pedúnculo e brácteas e bractéolas ausentes ( $v s$. flores em dicásios típicos com brácteas e bractéolas), além de ovário 3(4-5)-locular (vs. ovário (3)5-locular), (Fritsch et al. 2004, DinizNeres \& Silva 2017).

Considerando a escassez de estudos sobre Microlicia na região centro-oeste do Brasil, particularmente, no Estado de Goiás, realizou-se o tratamento taxonômico das espécies deste gênero ocorrentes no Parque Nacional da Chapada dos Veadeiros, as quais seguem descritas e comentadas quanto a distribuição geográfica, comparações morfológicas, contrastadas por meio de uma chave de identificação, ilustradas em suas características diagnósticas.

\section{Material e métodos}

O Parque Nacional da Chapada dos Veadeiros (PNCV) situa-se no Estado de Goiás (figura 1a), compreende os municípios de Alto Paraíso de Goiás e Cavalcante entre $13^{\circ} 50^{\prime}-14^{\circ} 12^{\prime} \mathrm{S}$ e $47^{\circ} 24^{\prime}-4^{\circ} 58^{\prime} \mathrm{W}$, e é uma das maiores Unidades de Conservação do Brasil (Felfili 2007). Possui uma área de 67.000 ha, distintos tipos de solos, clima CWbl com precipitação média anual entre 1.500 e $1.750 \mathrm{~mm}$ e temperatura entre 24 e $26^{\circ} \mathrm{C}$, vegetação composta por formações campestres e florestais (figura 1b-k), que abrigam uma flora pouco conhecida com espécies endêmicas e, ou raras, distribuídas entre 800 até 1.650 metros (Brasil 1982, Felfili et al. 2007).

Foram feitas coletas mensais na área de estudo desde 2014 até novembro de 2016, com duração de três a cinco dias conforme as recomendações de Mori et al. (1989). A identificação dos táxons foi feita por literatura especializada (e.g. Cogniaux 1891, Rodrigues 2005, Goldenberg et al. 2015) e por comparações com coleções herborizadas, incluindo typus, enquanto que as descrições dos mesmos foram baseadas em coleções de dentro do parque, e as variações morfológicas foram obtidas em 


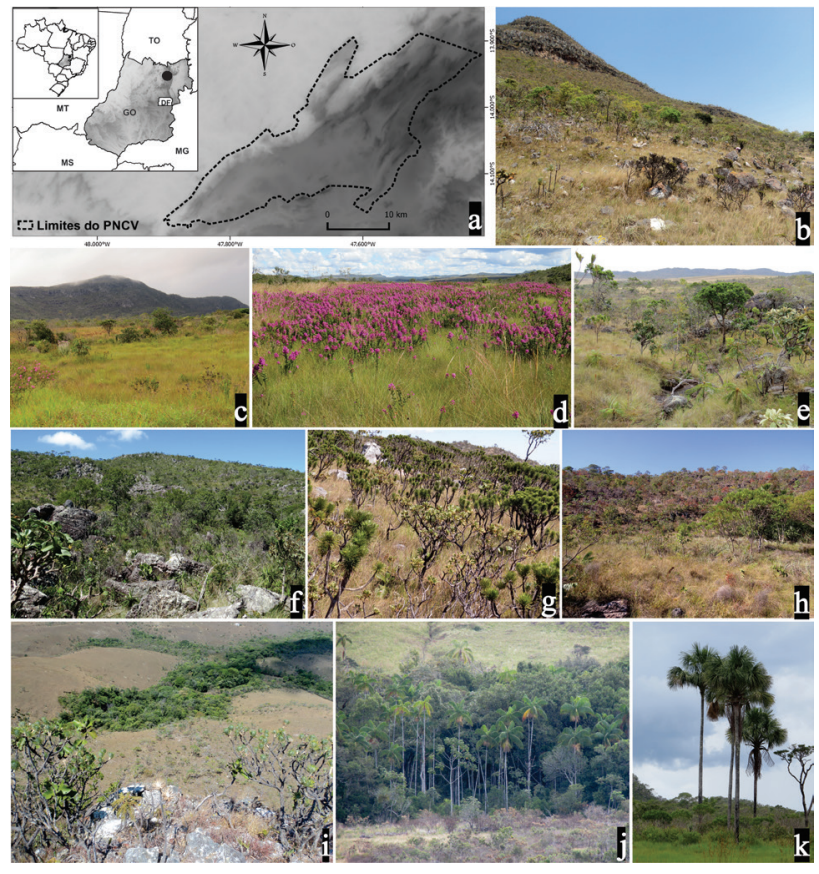

Figura 1. a. Mapa do Parque Nacional da Chapada dos Veadeiros, Estado de Goiás, Brasil. b. Campo cerrado. c. Campo sujo; d. Campo úmido. e. Cerrado ralo. f e g. Cerrado rupestre. h. Cerrado típico. i e j. Mata de galeria. k. Vereda.

Figure 1. a. Map of Chapada dos Veadeiros National Park, Goiás State, Brazil. b. Closed field. c. Dirty field. d. Wet field. e. Closed cave. fe g. Typical closed. h. Typical savanna. i e j. Gallery florest. k. Path.

coleções próprias, já depositadas no Herbário UFG, ou provenientes dos herbários (BHCB, CEN, COR, HEPH, IBGE, UB, UFG e HUFU, acrônimos segundo Thiers 2019, continuamente atualizado). Na descrição das espécies foram adotadas as terminologias citadas nas obras listadas para identificação das mesmas, e quando necessário, complementadas por informações de manuais básicos de morfologia vegetal (e.g. Radford et al. 1974, Harris \& Harris 1997).

As ilustrações das espécies constam dos principais caracteres úteis na identificação delas e foram feitas em estereomicroscópio Zeiss, com câmara clara acoplada. A abreviação das obras onde as espécies foram publicadas segue Taxonomic Literature (Stafleu \& Cowan 1976), enquanto que a dos nomes dos autores segue (Brummitt \& Powell 1992, IPNI 2016). As fotografias apresentadas são de crédito dos próprios autores do artigo. O mapa com a localização do PNCV foi confeccionado através do software QGIS version 2.8.2 (Quantum GIS Development Team 2015). Todas as etapas do estudo taxonômico foram desenvolvidas no Laboratório de Morfologia Vegetal e no Herbário da Universidade Federal de Goiás.

\section{Resultados e Discussão}

Microlicia D. Don, Mem. Wern. Nat. Hist. Soc. 4: 283. 1823.

Subarbustos, eretos ou decumbentes, arbustos ou árvores, anãs ou não. Caule e ramos quadrangulares, subcilíndricos ou cilíndricos, dicotômicos ou tricotômicos próximos ao ápice, com ou sem glândulas circulares, glabros, hirsutos ou seríceos, com tricomas glandulares ou não. Folhas sésseis ou pecioladas; lâminas com ou sem glândulas circulares em ambas as faces, de formas, consistências, dimensões, bases, ápices e margem variados, estas últimas ciliadas ou não; venação hifódroma ou acródroma com 3, 5, ou 7-nervuras. Flores solitárias ou em dicásios simples, terminais, com eixos suprimidos. Flores 4, 5 ou mais raramente 6-meras, pétalas brancas, púrpuras, rosa claro ou pink, sésseis ou pediceladas; hipanto campanulado, urceolado ou infundibuliforme com ou sem glândulas arredondadas ou tricomas, incluindo glandulares, externamente; lacínias do cálice lanceoladas ou triangulares, agudas e, ou apiculadas, ciliadas ou não, semelhantes ao hipanto quanto ao indumento e glândulas; pétalas obovais, glabras com ápices variados, ciliadas ou não; estames 10 ou menos frequentemente 12 ou 14, dimórficos ou subisomórficos com diferentes tamanhos, os antessépalos usualmente maiores de que os antepétalos, ambos com filetes amarelos ou róseos ${ }_{2}$ conectivo prolongado, apêndices achatados, inteiros a trilobados, amarelos ou róseos, além de anteras bi-poliesporangiadas com ou sem rostro, ovário 3-5-locular, súpero, não adnato à base do hipanto, glabro, com formas e cores variadas, incluindo de estiletes. Cápsulas com cores e formas variadas, hipanto persistente, deiscentes de cima para baixo. Sementes numerosas, reniformes ou oblongas com testa foveolada e cores variadas.

Microlicia mostrou-se representado por 18 espécies, quatro delas novas descobertas durante este estudo e já foram publicadas em outros artigos (M. chrysoglandulosa R. Romero, Versiane, Fontelas \& D.O. Diniz-Neres, M. veadeirana D.O. DinizNeres \& M. J. Silva, M. latifolia D.O. Diniz \& M.J. Silva e M. stenodonoides D.O. Diniz-Neres \& M.J. Silva), uma constitui nova ocorrência para Goiás (M. scoparia DC.), duas (M. crebropunctata Pilg., M. melanostagma Pilg.) são consideradas raras, e as demais comuns aos Estados de Goiás e Minas Gerais. 
Chave para espécies de Microlicia do Parque Nacional da Chapada dos Veadeiros

1. Arvores anãs ou até $2,3 \mathrm{~m}$ alt. e com ramos candelabriformes, folhas arranjadas nas terminações dos ramos em um aspecto de roseta 15. M. stenodonoides

1. Subarbustos, arbustos ou árvores até $1,5 \mathrm{~m}$. alt., mas sem ramos candelabriformes; folhas regularmente distribuídas nos ramos em um aspecto não semelhante a roseta

2. Folhas sem glândulas

3. Folhas coriáceas, imbricadas com ápices pungentes e margem não ciliado-glandular; flores 1,5-2,7 cm compr; hipanto indumentado 18. M. viminalis

3. Folhas cartáceas, não imbricadas com ápices não pungentes e margem ciliado-glandular; flores 0,8-1,2 cm compr.; hipanto glabro 9. M. melanostagma

2. Folhas com glândulas

4. Folhas cordadas a subcordadas

5. Caule ramificado em um aspecto corimbiforme; folhas com venação hifódroma raramente 3-5-nérvias; flores em tríades no ápice dos ramos em um aspecto dicasial; estames subisomórficos

5. M. cryptandra

5. Caule ramificado em um aspecto não corimbiforme; folhas com venação acródroma; flores solitárias em ramos encurtados na parte superior da planta; estames conspicuamente dimórficos

6. Lâmina foliar 7-21 × 3,8-15 mm, 5-nervada; anteras dos estames antessépalos vináceas 10. M. ordinata

6. Lâmina foliar 3,5-11 × 2-9 mm, 3-nervada; anteras dos estames antessépalos vermelhas ou róseas

12. M. ramosa

4. Folhas não cordadas

7. Folhas hifódromas, 1-nervada

8. Flores com pétalas brancas

9. Plantas 0,12-0,6 m; lâminas com ápice apiculado; hipanto róseo-esverdeado; lacínias do cálice com nervura calosa externamente; ovário 4-locular 13. M. scoparia

9. Plantas 0,7-1,4 m alt.; lâminas com ápice não apiculado; hipanto verde; lacínias do cálice sem nervura calosa externamente; ovário 3-locular 2. M. chrysoglandulosa

8. Flores com pétalas rosa magenta

10. Lâmina foliar lanceolada; rostro das anteras dos estames antessépalos 1,1-1,7 mm compr 11. M. psammophila

10. Lâmina foliar oval-lanceolada ou oblongo-elíptica; rostro das anteras dos estames antessépalos 0,2-0,9 mm compr.

11. Lâmina foliar com margem revoluta e não ciliada; hipanto com uma coroa de tricomas curtamente hirsuta no ápice

16. M. veadeirana

11. Lâmina foliar com margem plana e ciliada ou não; hipanto sem coroa de tricomas no ápice

12. Ramos jovens com glândulas; estames dimórficos com conectivos do ciclo antessépalo 3-5 mm compr. e apêndices 1,2-2 mm compr.

M. insignis

12. Ramos jovens sem glândulas; estames subisomórficos com conectivo do ciclo antessépalo 1,3-1,5 mm compr. e apêndices 0,2-0,5 mm compr. 1. M. acuminata

7. Folhas acródromas 3-5-nervadas

13. Limbo usualmente $0,6-4,5 \mathrm{~cm}$ compr.

14. Folhas membranáceas; cálice constricto na porção distal; estames antessépalos com anteras vermelhas 6. M. euphorbioides

14. Folhas cartáceas ou coriáceas; cálice não constricto na porção distal; estames antessépalos com anteras amarelas 
15. Ramos amarelados ou dourados; folhas não imbricadas; flores com pétalas brancas; lacínias do cálice menores ou do mesmo tamanho que o tubo, margem não ciliada 4. M crebropunctata

15. Ramos cremes ou alaranjados; folhas laxamente imbricadas; flores rosa magenta ou púrpuras; lacínias do cálice maiores que o comprimento do tubo, margem longamente ciliada 8. M. latifolia

13. Limbo usualmente com $0,3-1,6 \mathrm{~cm}$ compr.

16. Folhas ovais ou lanceoladas, estrigosas; anteras poliesporangiadas 17. M. vestita

16. Folhas elípticas, curtamente seríceas ou tomentosas; anteras bi-tetraesporangiadas

17. Plantas viscosas; folhas membranáceas; lacínias do cálice com glândulas internamente 3. M. consimilis

17. Plantas não viscosas; folhas cartáceas; lacínias do cálice sem glândulas internamente 14. M. serpyliifolia

\section{Microlicia acuminata Naudin, Ann. Sci. Nat., Bot.} sér. 3(3): 179. 1845.

Figuras 2 a-1, 3 a-f

Subarbustos 0,4-1 m alt., eretos, não cespitosos. Ramos dicotômicos, não corimbiformes, quando adultos quadrangulares, glabros, decorticantes, quando jovens, cilíndricos com numerosas glândulas punctiformes entremeadas com tricomas híspidos. Folhas sésseis, imbricadas; lâminas 5-8,5 × 1,5-2,5 mm, lanceoladas a oval-lanceoladas, cartáceas, base truncada ou obtusa, margem serreada e longamente ciliada, ápice acuminado, não pungente, 3-nérvias, longamente hirsuta na face abaxial e com numerosas glândulas arredondadas em ambas as faces. Flores 10-15 mm compr., 5-meras, solitárias, pedicelo 1,6-2,3 mm compr.; hipanto 3-5 × 2-4 mm, estreito campanulado, não costado, tomentoso-rosado externamente; lacínias do cálice 4-6,5 × 1,5-2,4 mm, lanceoladas, inteiras e não ciliadas, acuminadas com nervura calosa externamente, híspidas; pétalas 6-7 × 5,5-7 mm, róseas, obovais, glabras, margem não ciliada, ápice obtuso e mucronulado; estames 10, subisomórficos, os antessépalos com filetes 1,7-2,8 mm compr., amarelos, conectivos com 0,5-1 $\mathrm{mm}$ de prolongamento, amarelos, apêndices $0,1-0,6 \mathrm{~mm}$ compr., achatados, anteras $2-4 \times 0,4-0,6 \mathrm{~mm}$, amarelas, rostro $0,3-0,5 \mathrm{~mm}$ compr.; os antepétalos com filetes 1,7-2,5 mm compr., róseos, conectivos $0,5-1 \mathrm{~mm}$ de prolongamento, amarelos, apêndices $0,1-0,2 \mathrm{~mm}$ compr., achatados ou calosos, anteras 1,8-2,4 $\times 0,4-0,6 \mathrm{~mm}$, amarelas, rostro 0,2-0,5 $\mathrm{mm}$ compr, ambos com apêndices inteiros e anteras bi-tetraesporangiadas; ovário 2-3,5 × 1,5-2,4 mm, globoso, 3-locular, estilete 7,5-8,5 mm compr., róseo. Cápsulas e sementes não vistas.

Material examinado: Alto Paraíso de Goiás, vereda ao lado do Morro Chapado, 1407'12,6"S, 47º41'45,7"W,
1187 m, 04.VII.2015, fl., D.O. Diniz et al. 482, 483, 484, 485, 486 (UFG). Cavalcante, final do parque, 20.V.2016, fl., D.O. Diniz \& R.N. Ribeiro 908 (UFG).

Material examinado adicional: BRASIL. Goiás: Niquelândia, ca. 5 Km de Niquelândia, 25-I-1972, fl., H.S. Irwin et al. 34996 (UB). Pirenópolis, Serra dos Pireneus, 04.VI.1971, fl., J.A. Rizzo \& A. Barbosa $6375 A$ (UFG). Tocantins: Tupiratins, à esquerda da estrada para Tupiratins, à $6 \mathrm{Km}$ da cidade, 18-III-1972, fl., J.A. Rizzo 7898 (UFG).

Microlicia acuminata é referida por Romero \& Woodgyer (2015) para os Estados de Goiás e Mato Grosso. Neste estudo, mostrou-se representada apenas por seis indivíduos crescendo em campo sujo e úmido, coletada nos meses de maio e julho. Pode ser confundida com $M$. insignis pelas folhas lanceoladas a oval-lanceoladas com margem longamente ciliada, hipanto com tricomas róseos e lacínias do cálice com nervura calosa externamente. Porém, diferencia-se desta pelos ramos jovens híspidos, estames antessépalos com conectivos e apêndices com 0,5-1 mm e 0,1-0,6 mm compr., respectivamente. $M$. insignis possui ramos glabros, estames antessépalos com conectivos e apêndices com 3-5 mm e 1,2-2 mm compr., respectivamente.

2. Microlicia chrysoglandulosa R. Romero, Versiane, Fontelas \& D.O. Diniz-Neres, Syst. Bot., 42(3): 562. 2017.

Figuras 2 m-y, 4 a-f

Subarbustos 0,7-2 m alt., eretos, não cespitosos. Ramos dicotômicos, não corimbiformes, quando adultos cilíndricos e decorticantes, quando jovens quadrangulares com glândulas circulares, ambos glabros. Folhas sésseis, laxamente imbricadas; lâminas 3,2-5,3 × 0,6-1,1 mm, lanceoladas, cartáceas, base 


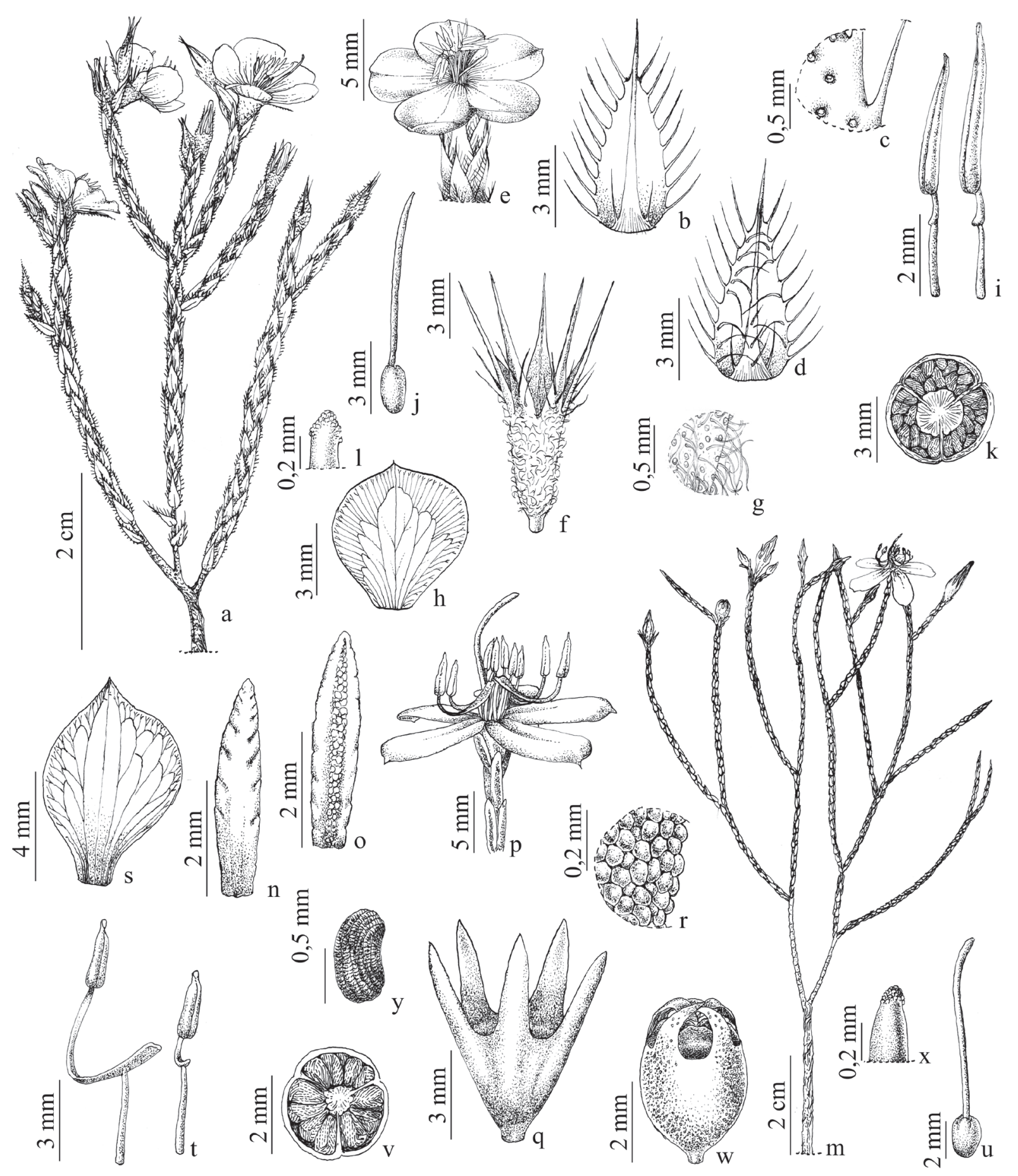

Figura 2. a-1. Microlicia acuminata Naudin. a. Hábito. b. Folha (face adaxial). c. Detalhe da margem foliar. d. Folha (face abaxial). e. Flor. f. Hipanto e Cálice. g. Detalhe do indumento do hipanto. h. Pétala. i. Estames, antessépalo (direita), antepétalo (esquerda). j. Gineceu (esquerda), detalhe do ápice do estilete (direita). k. Corte transversal do ovário. 1. Cápsula. m-y. M. chrysoglandulosa. m. Hábito. n. Folha (face adaxial). o. Folha (face abaxial). p. Flor. q. Cálice. r. Detalhe de indumento do cálice. s. Pétala. t. Estames, antessépalo (esquerda), antepétalo (direita). u. Gineceu. v. Corte transversal do ovário. x. Detalhe do ápice do estilete. w. Cápsula. y. Semente.

Figure 2. a-1. Microlicia acuminata Naudin: a. Habit. b. Leaf, adaxial surface. c. Leaf margin detail. d. Leaf, abaxial surface. e. Flower. f. Hypanthium and sepals. g. Hypanthium indumento detail. h. Petal. i. Larger stamen (right), Smaller stamen (left). j. Gynoecium (left), Apex of stigma (right). k. Cross section of 4-locular ovary. 1. Apex of stigma. m-y. M. chrysoglandulosa R. Romero, Versiane, Fontelas \& D.O. Diniz-Neres. m. Habit. n. Leaf, adaxial surface. o. Leaf, abaxial surface. p. Flower. q. Hypanthium and sepals. r. Hypanthium indumento detail. s. Petal. t. Larger stamen (left), Smaller stamen (right). u. Gynoecium. v. Cross section of 4-locular ovary. x. Apex of stigma. w. Mature fruit with hypanthium. y. Seed. 

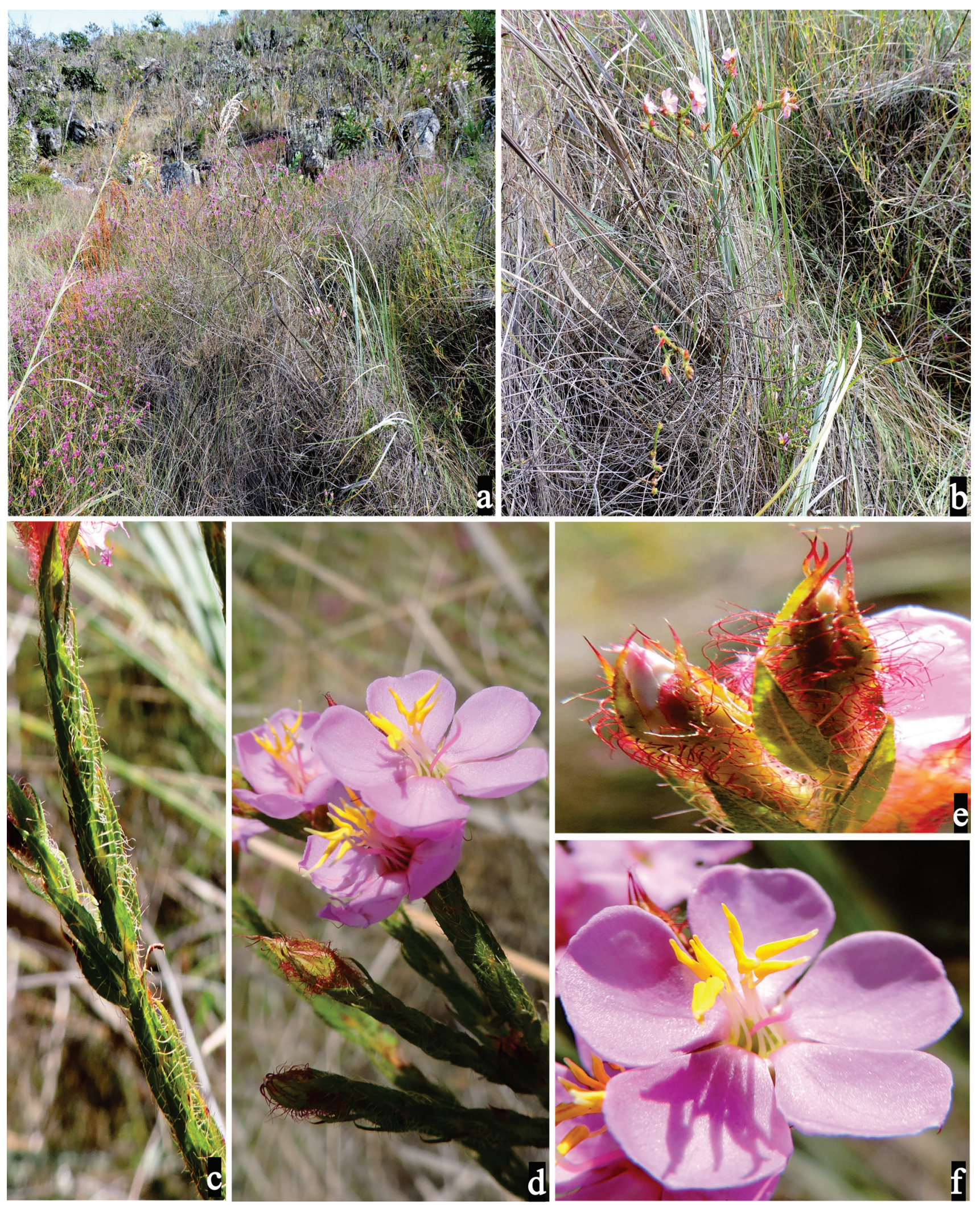

Figura 3. a-f: Microlicia acuminata Naudin. a. Habitat. b. Hábito. c. Ramo folhoso. d. Ramo fértil. e. Hipanto. f. Flor.

Figure 3. a-f. Microlicia acuminata Naudin. a. Habitat. b. Habit. c. Leafy branch. d. Fertile branch. e. Hypanthium. f. Flower. 

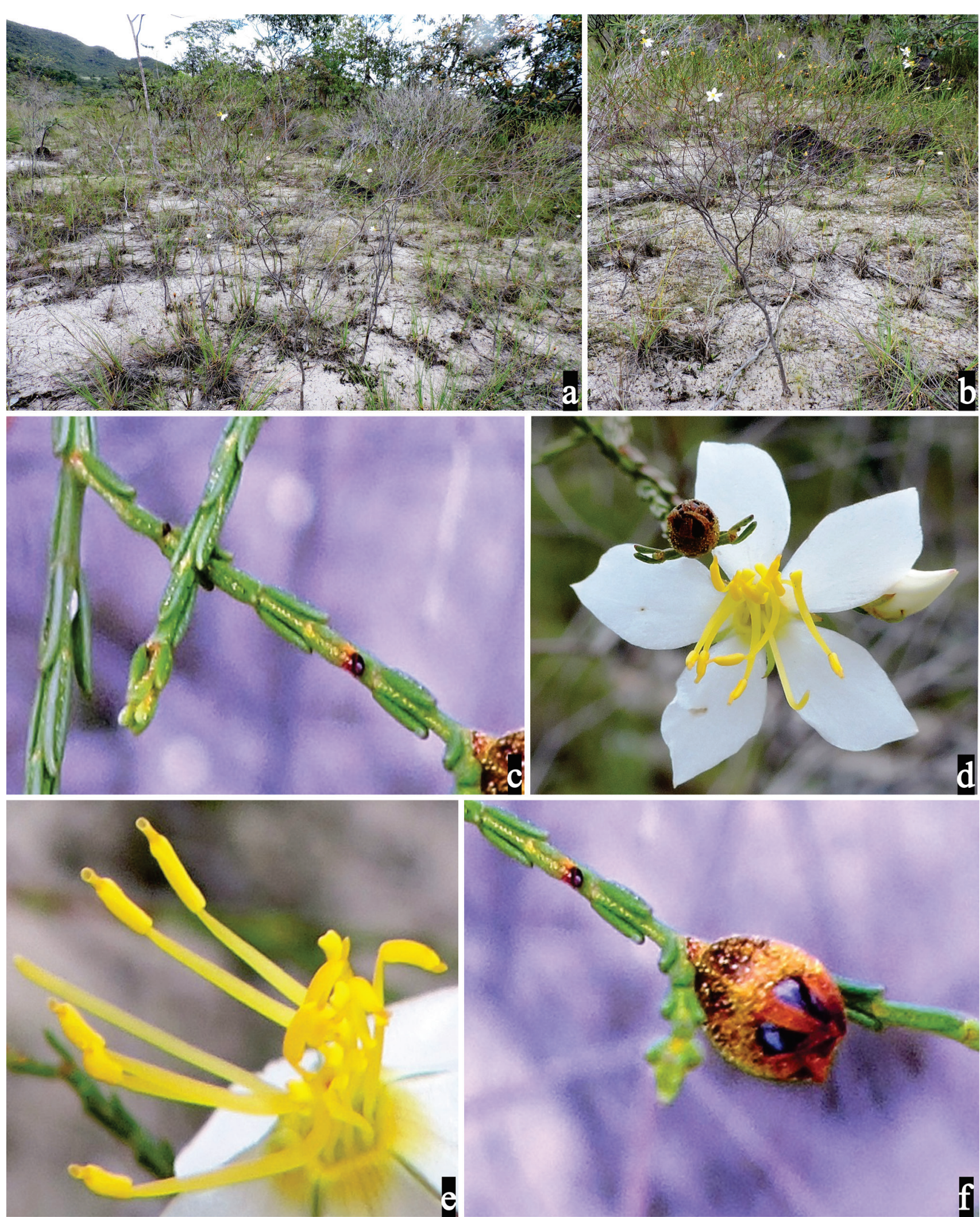

Figura 4. a-f. Microlicia chrysoglandulosa R. Romero, Versiane, Fontelas \& D.O. Diniz-Neres. a. Habitat. b. Hábito. c. Ramo folhoso. d. Flor. e. Androceu e gineceu. f. Cápsula.

Figure 4. a-f. Microlicia chrysoglandulosa R. Romero, Versiane, Fontelas \& D.O. Diniz-Neres. a. Habitat. b. Habit. c. Leafy branch. d. Flower. e. Androecium and gynoecium. f. Mature fruit with hypanthium. 
truncada, margem inteira ou discretamente crenada, não ciliada, ápice agudo, não pungente, 1-nérvias, com glândulas circulares douradas na face abaxial; Dicásios com eixos suprimidos e ou flores solitárias, ambos terminais. Flores 10-12 mm compr.,(4-)5-meras, pedicelo 0,8-1,5 mm compr.; hipanto 2-4 × 2,8-4,2 mm, campanulado, 10-costado, glabro com glândulas arredondadas e douradas externamente; lacínias do cálice 2-5 × 1-2 mm, lanceoladas, inteiras e não ciliadas, agudas, semelhantes ao hipanto; pétalas 7,9-11 × 3,3-5,8 $\mathrm{mm}$, brancas com base amarela, elíptico-obovais, glabras, agudas, margem não ciliada; estames 10, dimórficos, os antessépalos, com filetes 3,5-5,2 mm compr., conectivos com 5,2-7,1 mm de prolongamento, apêndices com 0,8-2,3 mm compr., anteras 1,9-2,6 $\times 0,4-1 \mathrm{~mm}$, rostro $0,6-1 \mathrm{~mm}$ compr., pode ocorrer a presença de estaminódios neste ciclo em alguns indivíduos; os antepétalos com filetes 3-4,3 mm compr., conectivos 1-2 mm de prolongamento, apêndices com 0,3-0,4 mm compr., anteras 1,8-2,5 × 0,5-1 mm, rostro 0,5-1 mm compr, ambos com filetes, anteras, prolongamentos dos conectivos e apêndices amarelos, estes últimos achatados e inteiros, e anteras tetraesporangiadas; ovário 1,8-2,2 × 1,0-1,4 mm, oblongoide ou elipsoide, 3-locular, estilete 7,8-10,5 mm compr., amarelo. Cápsulas 3-5,2 $\times 2-3,5 \mathrm{~mm}$, globosas, marrons ou douradas. Sementes 0,6-1,2 ×0,4-0,8 mm, oblongas, ligeiramente curvas ventralmente, vináceas.

Material examinado: Alto Paraíso de Goiás, Chapada dos Veadeiros, trilha para o Saltos, 22-III-2012 fl., A.I.M.R. Machado et al. 166 (holótipo) (HUFU); Alto Paraíso de Goiás, trilha que leva ao Salto de 80

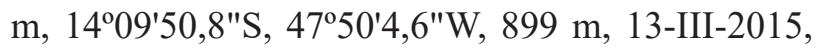
fl., D.O. Diniz et al. 89 (parátipo) (UFG); ib., $14^{\circ} 09^{\prime} 54,2^{\prime \prime S} 47^{\circ} 50^{\prime} 20,9^{\prime \prime} \mathrm{W}, 868$ m., ib., fl., D.O. Diniz et al. 92 (UFG); Trilha que leva ao Salto de $80 \mathrm{~m}$ e Cachoeira de 120 metros, $14^{\circ} 09^{\prime} 53^{\prime \prime S}$, 47050'20,3"W, 878 m, 02.V.2015, fl., fr. D.O. Diniz et al. 243 (parátipo), 244, 245, 246, 247 (UFG); estrada que leva às corredeiras, distrito de São Jorge, 3-II-2016, 140'10'8,6"S, 4749'35,8"W, 978 m, fl., D.O. Diniz et al. 768 (UFG); ib., $14^{\circ} 09^{\prime} 54,5^{\prime \prime S}$, 47050'20,7"W, 834 m, 30-IV-2016 fl., fr., D.O. Diniz et al. 874 (parátipo), 875, 876, 878, 880 (UFG), ib., fl., D.O. Diniz et al. 879 (UFG), ib., fr., D.O. Diniz et al. 877 (UFG); $3 \mathrm{Km}$ à nordeste dos alojamentos, $14^{\circ} 09^{\prime} 28,9^{\prime \prime} \mathrm{S}, 4^{\circ} 46^{\prime} 56,7^{\prime \prime} \mathrm{W}, 1126 \mathrm{~m}, 20-\mathrm{VIII}-2016$, fr., D.O. Diniz et al. 1089 (parátipo) (UFG).
Material examinado adicional: BRASIL: GoIÁs. Alto Paraíso de Goiás: GO-118, 15,5 Km ao norte de Alto Paraíso, 29-V-1994, fl., S. Splett 262 (UB), ib., Portal da Chapada em campo limpo, 23-II-2007, M.R.V. Zanatta 42 (UB). São João da Aliança: Chapada dos Veadeiros, 5-15 Km sul da Chapada dos Veadeiros, 21-VII-1964, fl., G.T. Prance \& N.T. Silva 58285 (UB).

Espécie recentemente publicada (Romero et al. 2017) e provavelmente endêmica da Chapada dos Veadeiros onde ocorre nos municípios de Alto Paraíso de Goiás e São João da Aliança. Habita distintos tipos de fitofisionomias (e.g., cerrado rupestre e campos limpos e úmidos) sobre solos areno-argilosos entre 878 e 1000 metros de altitude, coletada com flores de fevereiro a maio e com frutos de maio a agosto.

Assemelha-se a M. psammophila, também encontrada neste estudo, pelas folhas pequenas, cartáceas e com glândulas. Entretanto, M. psammophila é uma espécie comumente cespitosa até $0,5 \mathrm{~m}$ alt., com flores de pétalas róseas e todos os estames férteis. Em Microlicia chrysoglandulosa o caule não é cespitoso, varia de 0,7-2 $\mathrm{m}$ alt., as flores possuem pétalas brancas e com estames do ciclo antessépalo podem em alguns indivíduos apresentar anteras malformadas. Em exsicatas fora da área de estudo observou-se indivíduos da mesma com pétalas róseas. Pode ser confundida ainda com $M$. scoparia por ambas possuírem flores brancas com estames de ambos os ciclos amarelos e folhas lanceoladas com glândulas arredondadas. Mas, $M$. scoparia atinge $0,12-60 \mathrm{~cm}$ alt., possui hipanto róseo-esverdeado, lâmina com ápice curto apiculado, lacínias do cálice com nervura calosa na face externa e ovário 4-locular, já em Microlicia chrysoglandulosa o hábito atinge 0,7-2 $\mathrm{m}$ alt., o hipanto é verde, as folhas possuem ápices agudos e não apiculados, as lacínias do cálice não possuem nervuras calosas externamente e ovário é 3-locular.

3. Microlicia consimilis Wurdack, Los Angeles County Mus. Contr. Sci. 28: 6. 1959.

Figuras 5 a-m, 6 a-c

Subarbustos 0,4-1 m alt., viscosos, eretos, não cespitosos. Ramos dicotômicos e tricotômicos, não corimbiformes, quando adultos, cilíndricos, glabros e decorticantes, quando jovens quadrangulares e hirsutos com glândulas punctiformes. Folhas sésseis ou com pecíolo 0,3-1 mm compr., não imbricadas; lâminas 4,3-16,5 × 1,3-4,5 mm, elípticas ovalelípticas, membranáceas, base obtusa, margem 


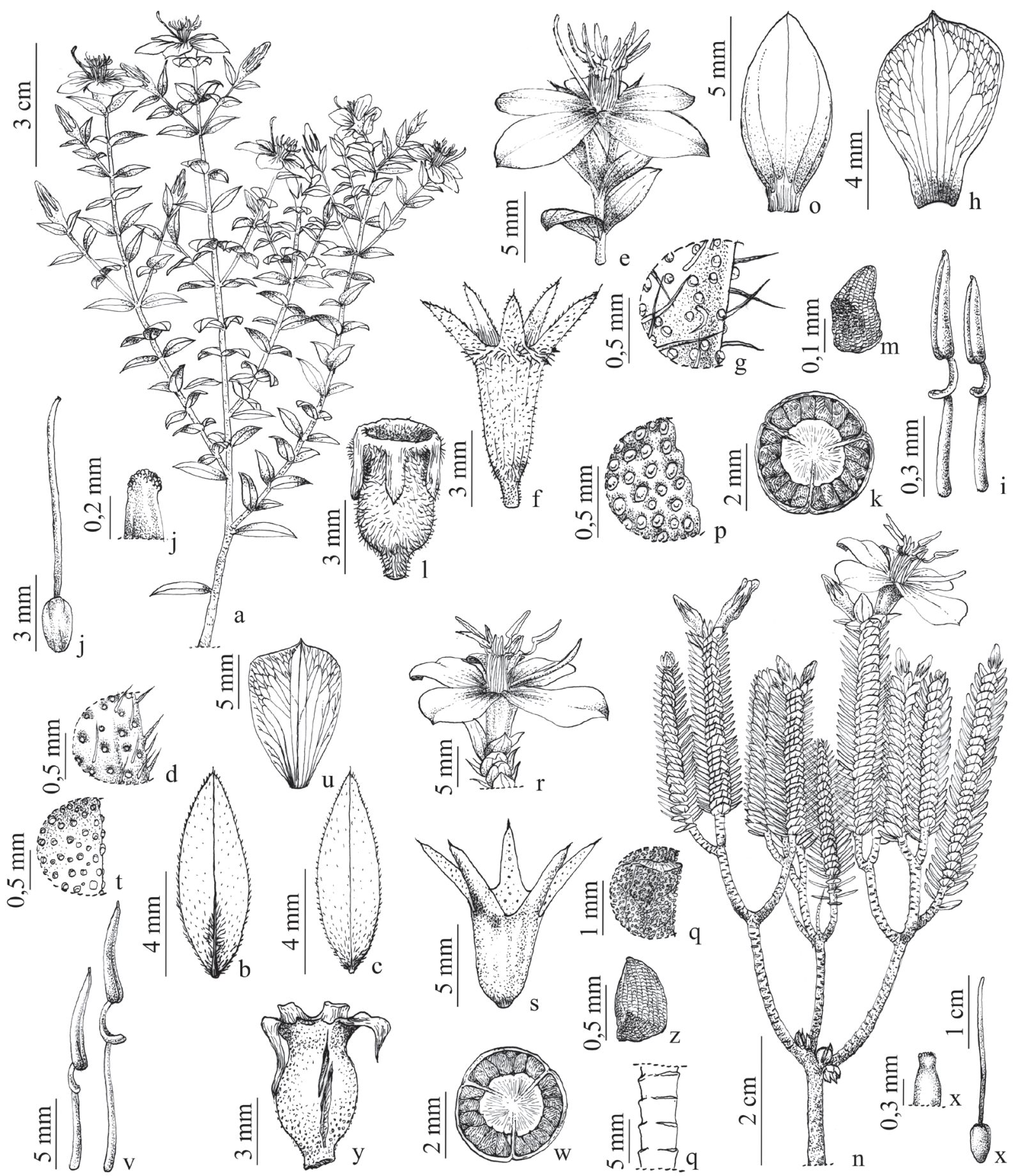

Figura 5. a-m. Microlicia consimilis Wurdack. a. Hábito. b. Folha (face adaxial). c. Folha (Face abaxial). d. Detalhe do indumento foliar. e. Flor. f. Cálice. g. Detalhe do indumento do hipanto. h. Pétala. i. Estames, antessépalo (esquerda), antepétalo (direita). j. Gineceu e detalhe de seu ápice. k. Corte transversal do ovário. 1. Cápsula. m. semente. n-z. M. crebropunctata Pilg. n. Ramo fértil. o. Folha. p. Detalhe das glândulas da folha. q. Ramo e detalhe de suas glândulas. r. Flor. s. Cálice. t. Detalhe das glândulas do cálice. u. Pétala. v. Estames, antessépalo (direita), antepétalo (esquerda). x. Gineceu e detalhe de seu ápice. w. Corte transversal do ovário. y. Cápsula. z. Semente.

Figure 5. a-m. Microlicia consimilis Wurdack. a. Habit. b. Leaf, adaxial surface. c. Leaf, abaxial surface. d. Leaf Indument Detail. e. Flower. f. Hypanthium and sepals. g. Hypanthium indumento detail. h. Petal. i. Larger stamen (left), Smaller stamen (right). j. Gynoecium and Apex of stigma. k. Cross section of 4-locular ovary. 1. Mature fruit with hypanthium. m. Seed. n-z. M. crebropunctata Pilg. n. Fertile branch. o. Leaf. p. Detail of leaf glands. q. Branch and detail of your glands. r. Flower. s. Hypanthium and sepals. t. Detail of calyx glands. u. Petal. v. Larger stamen (left), Smaller stamen (right). x. Gynoecium and detail of its apex. w. Cross section of ovary. y. Mature fruit with hypanthium. z. Seed. 


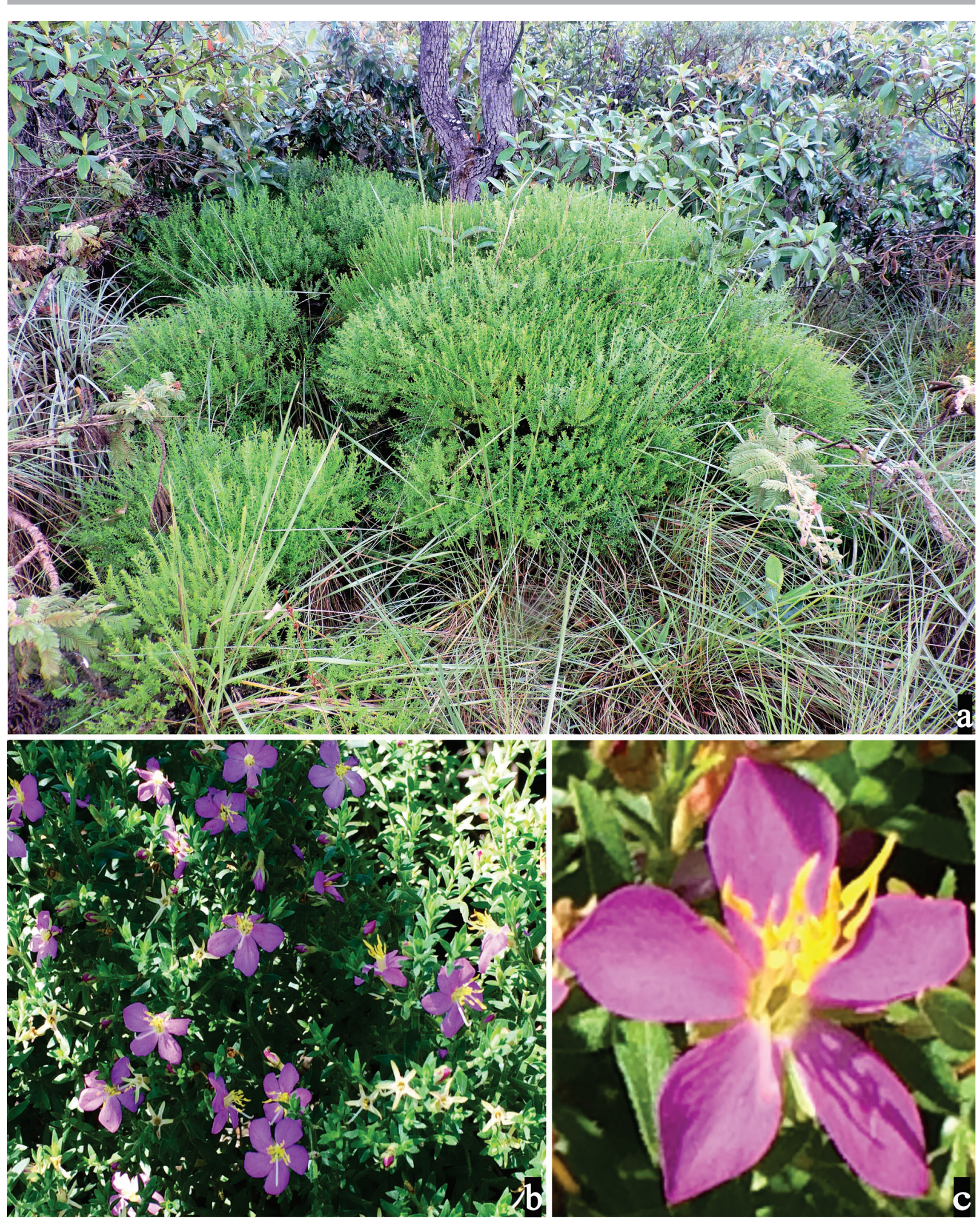

Figura 6. a-c. Microlicia consimilis Wurdack. a. Hábito. b. Ramo fértil. c. Flor.

Figure 6. a-c. Microlicia consimilis Wurdack. a. Habit. b. Fertile branch. c. Flower. 
inteira e ciliada, ápice agudo e mucronulado, não pungente, 1-3-nérvias, curtamente seríceas e com glândulas punctiformes em ambas as faces, estas últimas mais evidentes na face abaxial. Dicásios com eixos suprimidos e ou flores solitárias, ambos terminais. Flores 11-13 mm compr., 5-meras, pedicelo 0,8-1,5 mm compr.; hipanto 4,8-5,7 × 2,5-3,7 mm, estreito campanulado, não costado, curtamente hirsuto e com glândulas punctiformes externamente; lacínias do cálice 3,5-4,4 × 1,3-2 mm, triangulares, inteiras e ciliadas, apiculadas, semelhantes ao hipanto externamente; pétalas 6-9 × 3,3-5,2 mm, róseas, obovais, glabras, ápice oblíquo-obtuso com tricoma hirsuto-glandular, margem não ciliada, estames 10 , subisomórficos, os antessépalos com filetes 3-4 mm compr., conectivos com 1,3-2,3 mm de prolongamento, apêndices $0,4-0,8 \mathrm{~mm}$ compr., anteras 2-3,5 × 0,7-1,2 mm, amarelas; os antepétalos com filetes 2,8-3,2 mm compr., conectivos $0,8-1,5 \mathrm{~mm}$ de prolongamento, apêndices $0,3-0,5 \mathrm{~mm}$ compr., anteras 1,8-3,7 × 0,7-1 mm, amarelas, ambos com filetes amarelos com máculas róseas ou não, anteras, prolongamentos dos conectivos e apêndices amarelos, estes últimos achatados, inteiros ou bilobados com anteras bi-tetraesporangiadas com rostro $0,2-0,3 \mathrm{~mm}$ compr; ovário 2,3-3 × 1,5-2 mm, oblongoide ou elipsoide, 3-locular, estilete 8,5-10,3 mm compr., róseo a esbranquiçado. Cápsulas 3-4,5 $\times 2$-3,5 mm, oblongoides douradas. Sementes 0,2-0,4 × 0,1-0,2 mm, oblongas, ligeiramente curvas ventralmente, douradas.

Material examinado: Alto Paraíso de Goiás, área lateral ao Morro da Baleia, $14^{\circ} 07^{\prime} 40,8^{\prime \prime} \mathrm{S}, 47^{\circ} 40^{\prime} 16,8^{\prime \prime} \mathrm{W}, 1235$ m, 20-IV-2015, fl., D.O. Diniz et al. 200, 203, 205 (UFG), ib., 14 $07^{\circ} 20,8^{\prime \prime S}, 47^{\circ} 39^{\prime} 59,2^{\prime \prime W}, 1234 \mathrm{~m}$, 20-IV-2015, fl., D.O. Diniz et al. 209, 210 (UFG); ca. $500 \mathrm{~m}$ da GO-239, em estrada desativada a oeste do morro da Baleia, $14^{\circ} 07^{\prime} 42^{\prime \prime} \mathrm{S}, 47^{\circ} 40^{\prime} 17^{\prime \prime} \mathrm{W}, 1230 \mathrm{~m}$, 20-IV-2015, fl., M.J. Silva et al. 6633, 6653 (UFG).

Material examinado adicional: BRASIL. Goiás: Alto Paraíso de Goiás, ca. $10 \mathrm{Km}$ de Alto Paraíso, 23-III-1969, fl., H.S. Irwin et al. 24939 (UB). Cocalzinho de Goiás, lado esquerdo da BR-414 em direção à Cocalzinho, morro próximo ao Salto de Corumbá, 3-X-2012, fr., Versiane, A.F.A. et al. 292 (UB); Corumbá de Goiás, Serra dos Pireneus, Salto de Corumbá, 19-II-2013, fl., Rocha, M.J.R.R. et al. 906 (BHCB).

Espécie endêmica do Estado de Goiás (Flora do Brasil 2020) e aqui coletada em cerrado típico ou ralo e em campo úmido entre 1.234-1.235 m de altitude com flores em abril.

Pode ser diagnosticada pelos ramos jovens hirsutos, folhas elípticas ou oval-elípticas, 1-3-nervadas, membranáceas, ciliadas e com numerosas glândulas circulares, as quais também ocorrem externamente nas lacínias do cálice. Compartilha com $M$. euphorbioides o aspecto geral dos ramos, as folhas elípticas e viscosas e as flores 5-meras com pétalas róseas e obovais. No entanto, M. consimilis possui folhas 1-3-nérvias com margem inteira e ciliada ( $v s$. 3-5-nérvias com margem serreada e ciliado-glandular em $M$. euphorbioides), hipanto não constricto na região mediana ( $v s$. constricto), lacínias do cálice com glândulas arredondadas em ambas as faces (vs. apenas externamente), ovário oblongoide (vs. ovário ovoide), e anteras dos estames antessépalos amarelas com prolongamento do conectivo 1,3-2,3 mm compr. ( $v s$. vermelhas e com prolongamento do conectivo entre 2,6-3,3 mm).

4. Microlicia crebropunctata Pilg., Bot. Jahrb. Syst. 33: 17. 1903.

Figuras 5 n-z, 7 a-g

Arbustos a árvores $0,6-3,5 \mathrm{~m}$ alt., eretos, não cespitosos. Ramos dicotômicos, amarelados a dourados, não corimbiformes, quando adultos, cilíndricos, glabros, decorticantes com cicatrizes foliares evidentes, quando jovens quadrangulares a subcilíndricos e glabros com glândulas arredondadas e douradas. Folhas sésseis ou com pecíolo 0,4-0,6 mm compr., laxamente imbricadas; lâminas 12-15,2 × 4,1-8,2 mm, elípticas, coriáceas, base obtusa, margem inteira a discretamente crenada, ápice obtuso, não pungente, 1 ou 3-nérvias, glândulas em ambas as faces. Flores 16-24 mm compr., solitárias, sésseis, 5(-6)-meras; hipanto 6-8 × 3-6,2 mm, campanulado, não costado, glabro, com glândulas arredondadas externamente; lacínias do cálice 5,8-7,3 × 1,8-3 mm, lanceoladas, inteiras, agudas, apiculadas, semelhantes ao hipanto em ambas as faces; pétalas 12,8-15 × 8,2-10 mm, brancas, obovais, glabras, ápice oblíquo mucronulado, margem não ciliada; estames 10(-12), subisomórficos, os antessépalos com filetes 4-8 mm compr., conectivos com 1,7-3,5 mm de prolongamento, apêndices $0,4-1,2 \mathrm{~mm}$ compr.,anteras 4,7-8,5 × 0,8-1,2 mm, amarelas; os antepétalos com filetes 3,1-7 mm compr., conectivos $0,8-2 \mathrm{~mm}$ de prolongamento, apêndices $0,2-1 \mathrm{~mm}$ compr., anteras 3-6,5 $\times$ 0,7-1,1 mm, amarelas, ambos com filetes, 

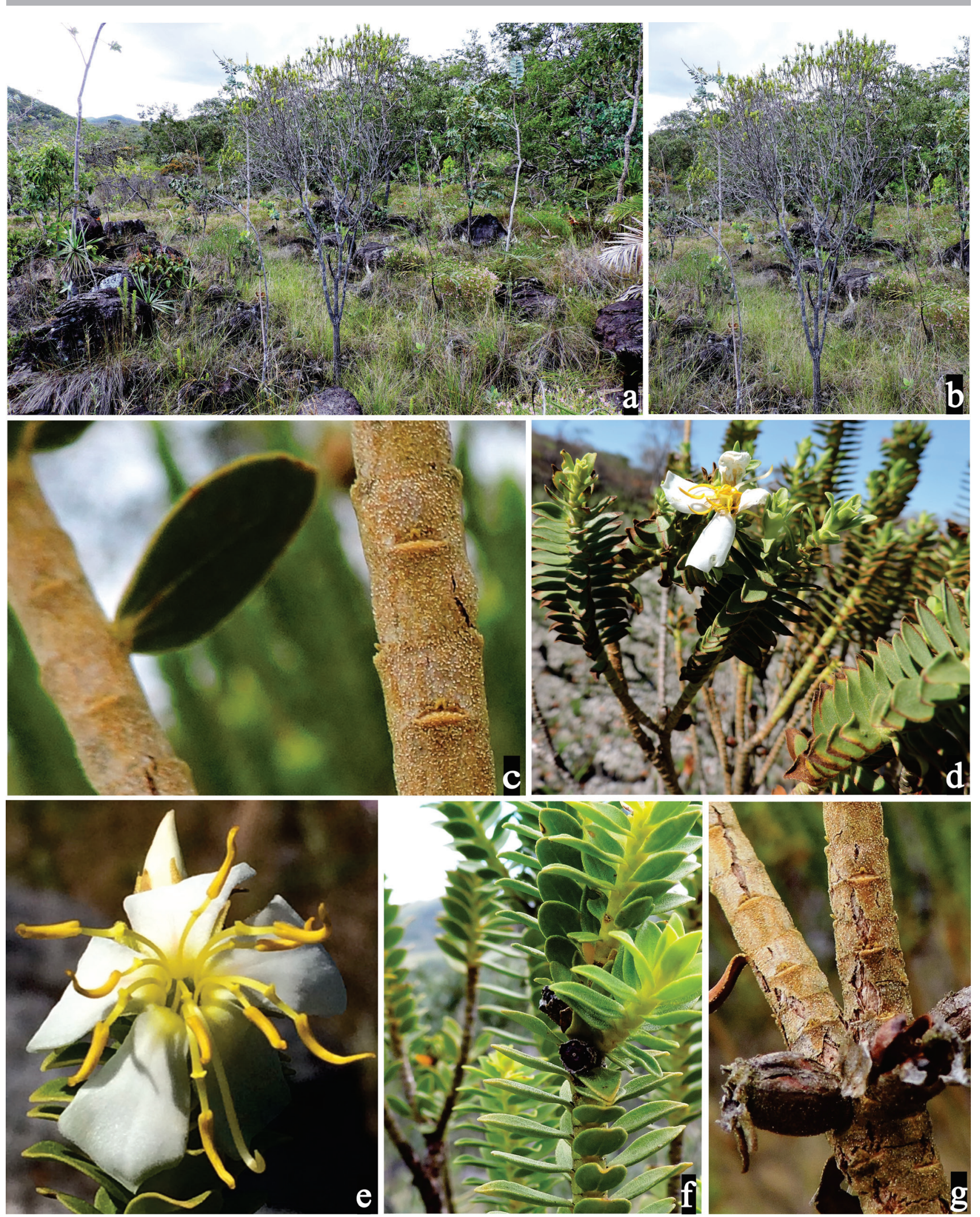

Figura 7. a-g. Microlicia crebropunctata Pilg. a. Habitat. b. Hábito. c. Ramo com glândulas. d. Ramo fértil. e. Flor. f e g. Cápsulas.

Figure 7. a-g. Microlicia crebropunctata Pilg. a. Habitat. b. Habit. c. Branch with glands. d. Fertile branch. e. Flower. fe g. Mature fruits with hypanthium. 
anteras, prolongamentos dos conectivos e apêndices amarelos, estes últimos achatados e bilobados, anteras bi ou tetraesporangiadas, não rostradas ou com rostro 0,1-0,3 mm compr; ovário 3-4 × 2-3 mm, oblongoide ou elipsoide, 3-locular, estilete 10-16 mm compr., amarelo. Cápsulas 6,2-10 × 4,2-5,2 mm, suburceoladas, vináceas, marrons. Sementes 0,8-1,5 × 0,5-1 mm, trapeozidais, douradas ou castanhas.

Material examinado: Alto Paraíso de Goiás, trilha que leva ao Salto de $80 \mathrm{~m}$, cerca de $300 \mathrm{~m}$ da bifurcação para as Corredeiras do rio Preto, $14^{\circ} 09^{\prime} 42,8^{\prime \prime} \mathrm{S}$, 47050'12,6"W, 863 m, 31-X-2014, fl., fr., R.C. Sodré et al. 1473 (UFG); trilha que leva ao Salto de $80 \mathrm{~m}$ e $120 \mathrm{~m}, 1^{\circ} 09^{\prime} 47^{\prime \prime S}, 47^{\circ} 50^{\prime} 08^{\prime \prime} \mathrm{W}, 10-\mathrm{IX}-1996$, fl., R.C. Mendonça et al. 2659 (UFG), ib., 1409'49,9"S, 47049'55"W, 930 m, 02.V.2015, fr., D.O. Diniz et al. 242 (UFG); imediações do rio Preto ca. 3,5 Km à Nordeste, $14^{\circ} 08^{\prime} 30^{\prime \prime} \mathrm{S}, 47^{\circ} 47^{\prime} 34^{\prime \prime} \mathrm{W}, 1024 \mathrm{~m}$, 5-VI-2015, fr., D.O. Diniz et al. 409 (UFG); trilha que leva à Cachoeira das 7 Quedas, $14^{\circ} 06^{\prime} 35,1^{\prime \prime} \mathrm{S}$, 47 $44^{\prime} 55,3^{\prime \prime} \mathrm{W}, 1175$ m, 7-X-2015, fl., fr. D.O. Diniz et al. 617 (UFG); ib, 14 $066^{\prime} 28,9^{\prime \prime} \mathrm{S}, 4^{\circ} 44^{\prime} 54,6^{\prime \prime} \mathrm{W}$, 1181 m, 7-X-2015, fl., fr. D.O. Diniz et al. 640, 642, 644, 645 (UFG); ib., fl., D.O. Diniz et al. 641, 643 e 646 (UFG), ib., 14 $06^{\circ} 57,8^{\prime \prime} \mathrm{S}, 47^{\circ} 44^{\prime} 49,8^{\prime \prime} \mathrm{W}, 1218 \mathrm{~m}$, 12-XII-2015, fl., D.O. Diniz 734, 735 (UFG); estrada para as Corredeiras, $14^{\circ} 10^{\prime} 22,7^{\prime \prime} \mathrm{S}, 47^{\circ} 49^{\prime} 34,8^{\prime \prime} \mathrm{W}$, 991 m, 3-II-2016, fl., D.O. Diniz 760, 770 (UFG).

Endêmica do Estado de Goiás (Flora do Brasil 2020). Coletada em no cerrado ralo ou rupestre e em campo úmido com flores em fevereiro, setembro a outubro e frutos em maio, junho, outubro e dezembro. Pode ser reconhecida pela combinação do hábito arbustivo ou arborescente, folhas elípticas com numerosas glândulas douradas além de flores grandes (ca. $24 \mathrm{~mm}$ compr.) com pétalas brancas e estames amarelos. Assemelha-se às espécies de Lavoisiera pelo aspecto das folhas e dos ramos. Mas, por possuir cápsulas deicentes do ápice para a base e flores pentâmeras, melhor se enquadra em Microlicia, uma vez que táxons de Lavoisiera possuem cápsulas deicentes da base ao ápice e flores 6-8-meras.

5. Microlicia cryptandra Naudin, Ann. Sci. Nat., Bot. sér. 3, 3: 175. 1845.

Figuras 8 a-n, 9 a-e

Subarbustos ou arbustos 0,3-1,3 m alt., eretos, não cespitosos. Ramos dicotômicos e tricotômicos, corimbiformes, quando adultos, cilíndricos a quadrangulares, glabrescentes ou glabros e descorticantes; quando jovens hirsutos a pubescentes com glândulas arredondadas. Folhas sésseis, imbricadas; lâminas 2-9,2 × 1,5-7 mm, cordadas, cartáceas, base cordada, margem híspido-ciliada, ápice obtuso, não pungente, 1-(3-5)-nérvias, curtamente seríceas ou pubescentes e com glândulas em ambas as faces. Dicásios com eixos suprimidos e ou flores solitárias, ambos terminais. Flores $7-17 \mathrm{~mm}$ compr., 5-(6)-meras, sésseis ou com pedicelo 0,5-1,2 mm compr.; hipanto 4-7 × 2,5-5,7 mm, 10-costado, campanulado, tomentoso ou seríceo-hialino ou vináceo com glândulas arredondadas externamente; lacínias do cálice 2,6-6,5 × 1,5-3,2 mm, triangulares, ciliadas, agudas e apiculadas, semelhantes ao hipanto; pétalas 7,2-11 × 4,3-8 mm, róseas, obovais ou elíptico-obovais, glabras ou esparsamente pubescentes em ambas as faces, margem ciliada, ápice oblíquo e apiculado; estames 10(12), subisomórficos, os antessépalos com filetes 3-5,3 mm compr., róseo-amarelados, conectivos com 1,1-2,7 $\mathrm{mm}$ de prolongamento, apêndices $0,4-1 \mathrm{~mm}$ compr., bilobados, anteras 4,1-5,2 × 0,6-1,3 mm, amarelas, rostro 0,2-0,5 mm compr.; os antepétalos com filetes $2,7-4,3 \mathrm{~mm}$ compr., róseos, conectivos 0,9-1,6 $\mathrm{mm}$ de prolongamento, apêndices 0,1-0,7 mm compr., inteiros, anteras 2,8-4,2 × 0,6-1,5 mm, amarelas, rostro 0,2-0,4 mm compr; ambos com anteras, prolongamentos dos conectivos e apêndices amarelos, estes últimos achatados e anteras bi ou tetraesporangiadas; ovário 1,7-3,2 × 1,3-2,3 mm, elipsoide, 3-locular, estilete 10-13,5 mm compr., róseo em toda extensão ou no terço superior. Cápsulas 4-8 × 3,5-5,2 mm, globosas, castanho-claras. Sementes 0,5-1 × 0,3-0,6 mm, oblongas, marrons ou negras.

Material examinado: Alto Paraíso de Goiás, próximo à Cachoeira do rio Preto, 6-II-1958, fl., fr., J.R. Pirani et al. 1658 (UB); trilha saindo da sede dos visitantes em direção ao Morro da Baleia, 14¹0'0,3"S, 4748'36"W, 1030 m, 19-XI-2013, fl., R.B.N. Alves et al. 67 (CEN); na margem da estrada entre a trilha das carioquinhas e do Salto, 14¹0'16"S, 4709'41"W, 979 m, 6-V-2014, fl., R.B.N. Alves et al. 105 (CEN); proximidades do morro Peito de Moça, após atravessar o rio Preto, 5-IX-2014, fl., L.S. Inocencio et al. 95 (UFG); Após a bifurcação que leva às 7 quedas do rio Preto, 1406'43,9"S, 4744'10,3"W, 1156 m, 15-II-2015, fl., D.O. Diniz et al. 13, 14 (UFG); Trilha em direção ao Salto de $80 \mathrm{~m}, 14^{\circ} 09^{\prime} 51,9^{\prime \prime} \mathrm{S}, 47^{\circ} 49^{\prime} 46,1^{\prime \prime} \mathrm{W}, 951 \mathrm{~m}$, 13-III-2015, fl., D.O. Diniz et al. 74 (UFG); ib., fl., fr., D.O. Diniz et al. 72, 75 (UFG); ib., 1409'48, 8"S, 


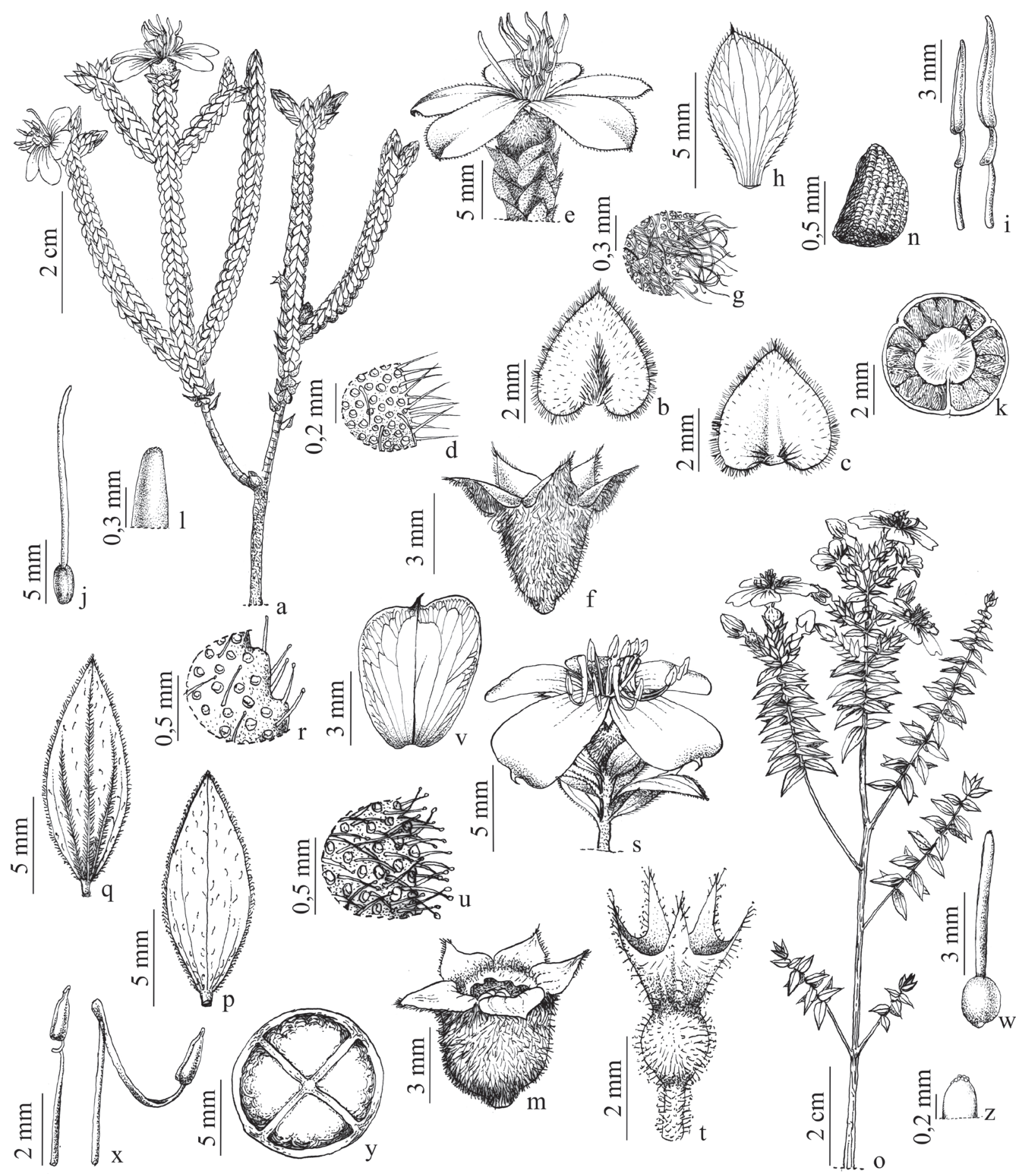

Figura 8. a-n. Microlicia cryptandra Naudin. a. Ramo fértil. b. Folha (face adaxial). c. Folha (face abaxial). d. Detalhe do indumento foliar. e. Flor. f. Cálice. g. Detalhe do indumento do hipanto. h. Pétala. i. Estames, antessépalo (direita), antepétalo (esquerda). j. Gineceu. k. Corte transversal do ovário. 1. Detalhe do ápice do estilete. m. Cápsula. n. Semente. o-z. M. euphorbioides Mart.. o. Ramo fértil. p. Folha (face adaxial). q. Folha (face abaxial). r. Detalhe de indumento da folha. s. Flor. t. Cálice. u. Detalhe do indumento do cálice. v. Pétala. x. Estames, antessépalo (direita), antepétalo (esquerda). w. Gineceu. y. Corte transversal do ovário. z. Detalhe o ápice do estilete.

Figure 8. a-n. Microlicia cryptandra Naudin. a. Fertile branch. b. Leaf, adaxial surface. c. Leaf, abaxial surface. d. Leaf Indument Detail. e. Flower. f. Hypanthium and sepals. g. Hypanthium indumento detail. h. Petal. i. Larger stamen (right), Smaller stamen (left). j. Gynoecium. k. Cross section of ovary. 1. Apex of stigma. m. Mature fruit with hypanthium. n. Seed. o-z. M. euphorbioides Mart.. o. Fertile branch. p. Leaf, adaxial surface. q. Leaf, abaxial surface. r. Leaf Indument Detail. s. Flower. t. Hypanthium and sepals. u. Hypanthium indumento detail. v. Petal. x. Larger stamen (right), Smaller stamen (left). w. Gynoecium. y. Cross section of ovary. z. Apex of stigma. 


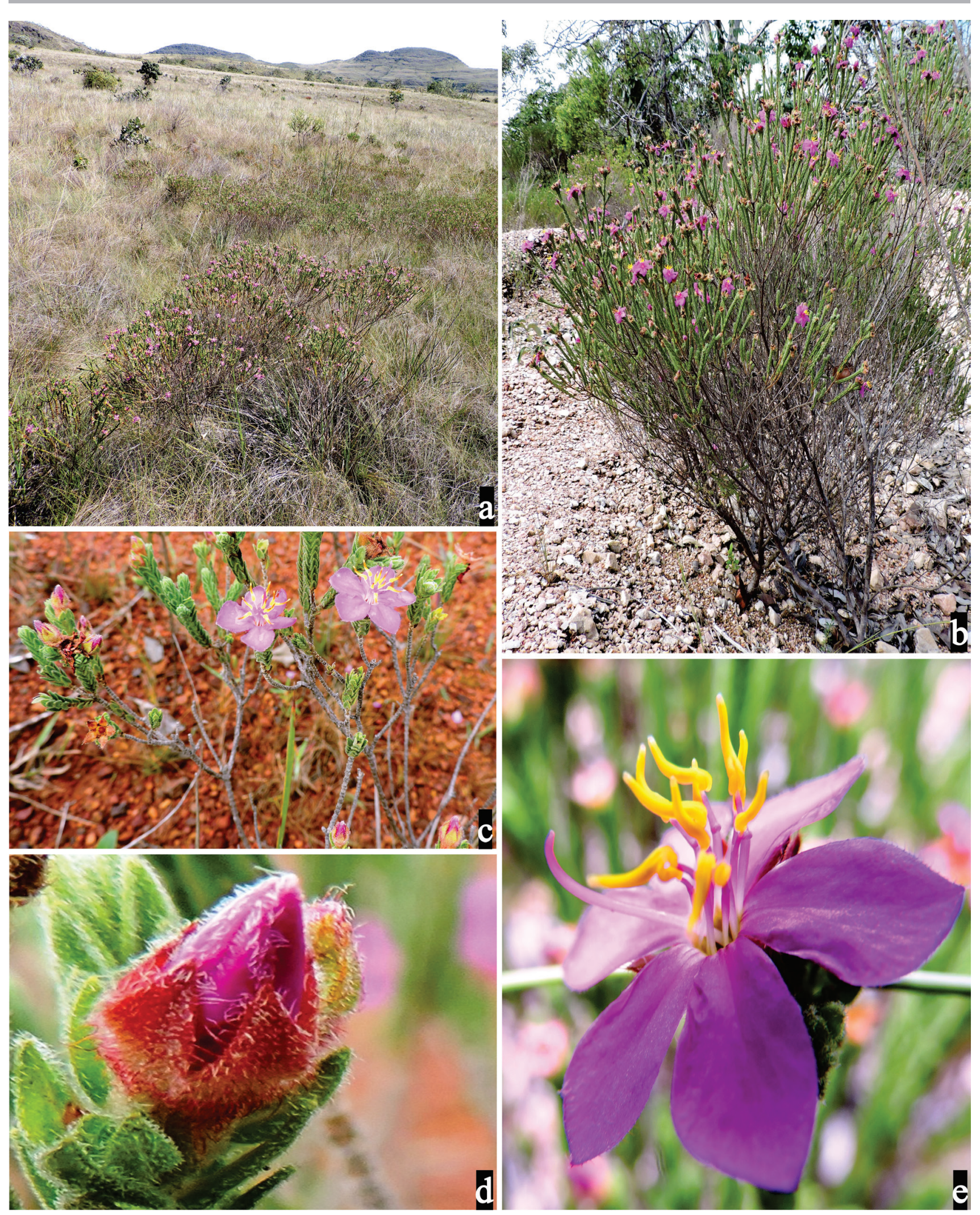

Figura 9. a-e. Microlicia cryptandra Naudin. a. Habitat. b. Hábito. c. Ramo fértil. d. Cálice. e. Flor.

Figure 9. a-e. Microlicia cryptandra Naudin. a. Habitat. b. Habit. c. Fertile branch. d. Hypanthium and sepals. e. Flower. 
47049'56,3"W, 914 m, 13-III-2015, fl., D.O. Diniz et al. 77 (UFG); ib., 1409'49, " $^{\prime \prime} \mathrm{S}, 47^{\circ} 49^{\prime} 55,5^{\prime \prime} \mathrm{W}, 920$ m, 13-III-2015, fl., fr. D.O. Diniz et al. 83 (UFG); Margem esquerda da GO-118, sentido Alto Paraíso de Goiás- Teresina, 13ำ $59^{\prime} 8^{\prime \prime} \mathrm{S}, 4^{\circ} 30^{\prime} 28,9^{\prime \prime} \mathrm{W}, 1525$ m, 19-IV-2015, fl., fr. D.O. Diniz et al. 161 (UFG); entrada principal para os alojamentos dos brigadistas, $14^{\circ} 09^{\prime} 58^{\prime \prime} \mathrm{S}, 4^{\circ} 47^{\prime} 25,8^{\prime \prime} \mathrm{W}, 1036 \mathrm{~m}, 20-\mathrm{IV}-2015$, fl., D.O. Diniz et al. 225, 226, 227, 332 (UFG); campo úmido lateral ao Morro da Baleia, lado oeste/ noroeste do morro, $14^{\circ} 07^{\prime} 13^{\prime \prime} \mathrm{S}, 47^{\circ} 39^{\prime} 51^{\prime \prime} \mathrm{W}, 1215 \mathrm{~m}$, 20-IV-2015, fl., M.J. Silva et al. 6660, 6661 (UFG); Distrito de São Jorge-Trilha trilha que leva ao Salto de 80 e 120 metros, $14^{\circ} 09^{\prime} 58,4^{\prime \prime} \mathrm{S}, 47^{\circ} 49^{\prime} 34,6^{\prime \prime} \mathrm{W}, 978 \mathrm{~m}$, 2-V-2015, fl., fr. D.O. Diniz et al. 228, 233 (UFG); Trilha oposta a trilha dos alojamentos do Parque no sentido dos Cânions, $14^{\circ} 09^{\prime} 38,5^{\prime \prime} \mathrm{S}, 4^{\circ} 47^{\prime} 44,1^{\prime \prime} \mathrm{W}$, 1078 m, 3-V-2015, fl., D.O. Diniz et al. 300 e 301 (UFG); trilha oposta dos alojamentos, rumo aos Cânions, 1409'38,5"S, 4704'44,1"W, 1078 m, 4-V-2015, fl., D.O. Diniz et al. 304, 305, 309, 311, 312, $313,326,332$ (UFG); GO-239, Km 72, à $500 \mathrm{~m}$ para dentro do parque, $14^{\circ} 08^{\prime} 18,6^{\prime \prime} \mathrm{S}, 47^{\circ} 44^{\prime} 8,8^{\prime \prime} \mathrm{W}, 1161 \mathrm{~m}$, 4-VI-2015, fl, fr., D.O. Diniz et al. 346, 347, 352, 353, $354,355,356,359,360$ (UFG); à $1 \mathrm{Km}$ a partir do alojamento na lateral do primeiro morro em direção ao rio Preto, $14^{\circ} 09^{\prime} 35,4^{\prime \prime} \mathrm{S}, 47^{\circ} 47^{\prime} 36,4^{\prime \prime} \mathrm{W}, 1074 \mathrm{~m}$, 5-VI-2015, fl., fr., D.O. Diniz et al. 368 (UFG),

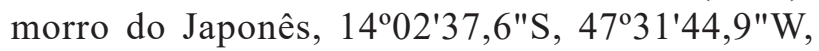
1530 m, 4-II-2016, fl., D.O. Diniz et al. 792 (UFG); lado esquerdo da antena próximo ao alojamento lobo guará, à $1 \mathrm{Km}$ do afluente do rio Preto, $14^{\circ} 08^{\prime} 48,4^{\prime \prime} \mathrm{S}$, 4747'23"W, 1203 m, 26-II-2016, fl., D.O. Diniz et al. 811,812 (UFG) à $400 \mathrm{~m}$ atrás do alojamento principal do parque, $14^{\circ} 09^{\prime} 32,3^{\prime \prime} \mathrm{S}, 47^{\circ} 47^{\prime} 34,8^{\prime \prime} \mathrm{W}, 1078 \mathrm{~m}$, 21-V-2016, fl., fr., D.O. Diniz et al. 926 (UFG); à 7 Km do morro do Japonês, à $20 \mathrm{Km}$ de Alto Paraíso na GO-118 em sentido Alto Paraíso à Teresina de Goiás, 135'ㄴ, 8"S, 47³0'32,5"W, 1495 m, 29-VII-2016, fl., D.O. Diniz et al. 945, 974A (UFG); Cavalcante, na região do córrego que divide Alto Paraíso de Goiás e Cavalcante, $13^{\circ} 56^{\prime} 34,3^{\prime \prime} \mathrm{S}, 4^{\circ} 29^{\prime} 43,1^{\prime \prime} \mathrm{W}, 1468 \mathrm{~m}$, 16-II-2015, fl., fr., D.O. Diniz et al. 65 (UFG); a esquerda da GO-118, sentido Alto Paraíso a Teresina de Goiás, ca. $200 \mathrm{~m}$ antes do final da cerca que limita o Parque a leste, $13^{\circ} 55^{\prime} 15^{\prime \prime} \mathrm{S}, 4^{\circ} 25^{\prime} 21$ "W, $1141 \mathrm{~m}$, 19-IV-2015, fl., M. J. Silva et al. 6589, 6616 (UFG); final do parque, sentido Teresina de Goiás, ca. $150 \mathrm{~m}$ à partir da estrada, $13^{\circ} 55^{\prime} 10,3^{\prime \prime} \mathrm{S}, 47^{\circ} 25^{\prime} 24,3^{\prime \prime} \mathrm{W}, 1396 \mathrm{~m}$, 20-XI-2015, fr., D.O. Diniz et al. 660, 661, 662 (UFG).
Material examinado adicional: BRASIL. GoIÁs: Alto Paraíso de Goiás, Chapada dos Veadeiros, ca. $12 \mathrm{Km}$ N.W. da chapada dos Veadeiros, 19-X-1965, fr., H.S. Irwin et al. 9312 (UB), ca. $10 \mathrm{Km}$ de Alto Paraíso, 24-III-1969, fl., fr., H.S. Irwin et al. 25001 (UB), ib., em campo rupestre, 30-XI-1971, fl., fr., J.A. Rizzo 7240 (UFG), ib., ca. $5 \mathrm{Km}$ de Alto Paraíso de Goiás, 15-II-1979, fl., Gates \& Estabrook 196 (UB), ib., 15,8 $\mathrm{Km} \mathrm{S}$ de B.M.T. Walter et al. 626 (CEN), ib., $15 \mathrm{Km}$ de Alto Paraíso em direção à Terezina de Goiás, 23-V-1994, fl., C. Munhoz 147, 150 (UB), Cocalzinho de Goiás, Serra dos Pireneus, 21-II-2013, fl., Rocha, M.J.R.R. 931 (BHCB). Pirenópolis, Morro Cabeludo em campo, 14-XI-1993, fl., fr., Splett 179 (UB), ib., em afloramento rochoso, 28-VI-1996, fr., M.B. Alcantara 188 (UFG), Teresina de Goiás, $48 \mathrm{Km}$ de Alto Paraíso para Teresina de Goiás, 21-V-1994, fl., fr., C. Munhoz et al. 96 (UB).

Microlicia cryptandra é endêmica dos cerrados, campos rupestres e campos úmidos do Estado de Goiás (Flora do Brasil 2020, Santos 2003, Versiane 2014). Neste estudo foi encontrada em cerrado ralo próximo à córregos, campo sujo e em área antropizada entre 868 e 1549 metros. Floresce e frutifica de fevereiro a agosto, porém frutos também são encontrados entre março a abril, junho, outubro e novembro. Por possui hábito esguio, caule em geral muito ramificado distalmente, folhas cordadas, com ápices não pungentes, uninérvias, curtamente seríceas ou pubescentes em ambas as faces, além de estames praticamente inclusos no interior do cálice com anteras voltadas para o centro deste, torna-se facilmente reconhecida entre as demais congêneres.

6. Microlicia euphorbioides Mart., Nov. Gen. Sp. P1. 3(2): 107, 1831.

Figura $8 \mathrm{o}-\mathrm{z}$

Subarbustos ou arbustos 0,6-1,8 m. alt., eretos, não cespitosos. Ramos dicotômicos, não corimbiformes, quando adultos cilíndricos, quando jovens cilíndricos ou quadrangulares, ambos com glândulas arredondadas, sendo estas mais abundantes nos ramos jovens. Folhas com pecíolo 0,7-1,4 mm compr., não imbricadas; lâminas 6-23(-30) × 2-8(-12) mm, elípticas, membranáceas, base aguda, não amplexicaule, margem serreada e ciliado-glandular, ápice agudo, não pungente, 3-5-nérvias, curtamente seríceas e densamente glandular punctadas em ambas as faces, as glândulas mais evidentes na face adaxial. Flores 10-14 mm 
compr., solitárias, 5-meras, pedicelo 1,6-2 mm compr.; hipanto 3-5 × 2,8-4 mm, urceolado constricto na região mediana, 10-costado, com glândulas punctiformes; lacínias do cálice 2,3-3 × 1,3-2 mm, triangulares, inteiras, agudas, semelhantes ao hipanto; pétalas 6,2-9,2 $\times$ 5-7 mm, rosa pink, obovais, glabras, margem inteira com esparsas glândulas no terço superior, ápice oblíquo-mucronulado; estames 10, dimórficos, os antessépalos com filetes 4,2-5 mm compr., conectivos com 2,6-3,3 mm de prolongamento, apêndices 1,3-1,8 mm compr., anteras 1,6-2,2 × 0,7-1,1 mm, vermelhas, rostro $0,3-0,8 \mathrm{~mm}$ compr.; os antepétalos com filetes 3,2-4,5 $\mathrm{mm}$ compr, conectivos com 0,3-0,6 $\mathrm{mm}$ de prolongamento, apêndices $0,2-0,4 \mathrm{~mm}$ compr., anteras 1,4-2,2 × 0,8-1,2 mm, amarelas, rostro 0,4-0,6 mm compr., ambos com filetes e prolongamentos dos conectivos róseos e apêndices róseos a amarelados, estes últimos achatados e inteiros, e anteras poliesporangiadas; ovário 1,8-2,2 × 1,3-1,7 mm, elipsoide ou ovoide, 3-4-locular, estilete 4,8-6 mm compr., róseo. Cápsulas e sementes não vistas.

Material examinado: Alto Paraíso de Goiás, imediações do rio Preto cerca de $3 \mathrm{Km}$ a nordeste dos alojamentos do PNCV, $14^{\circ} 08^{\prime} 37,1^{\prime \prime S}, 47^{\circ} 47^{\prime} 37,4^{\prime \prime} \mathrm{W}, 1003 \mathrm{~m}$, 5-VI-2015, fl., D.O. Diniz et al. 386 (UFG); à 3,9 Km do Pouso Alto, após cadeia de rochas, 13056'27,1"S, 47030'2,9"W, 1071 m, 22-VIII-2015, fl., D.O. Diniz et al. 530 (UFG); estrada que leva à Cachoeira das sete Quedas, $14^{\circ} 05^{\prime} 44,5^{\prime \prime} \mathrm{S}, 47^{\circ} 45^{\prime} 1,6^{\prime \prime} \mathrm{W}, 1071 \mathrm{~m}$, 7-X-2015, fl., D.O. Diniz et al. 632, 633, 634 (UFG); cerca de $2 \mathrm{Km}$ à Norte do alojamento principal do Parque, rumo ao rio Preto, $14^{\circ} 08^{\prime} 37^{\prime \prime} \mathrm{S}, 47^{\circ} 47^{\prime} 37^{\prime \prime} \mathrm{W}$, 5-VI-2015, fl., M.J. Silva et al. 6746, 6747 (UFG).

Material examinado adicional: BRASIL. MinaS Gerais: Unaí, ca. $1 \mathrm{Km}$ à montante do eixo da barragem, em cerrado, $16^{\circ} 12^{\prime} 43^{\prime \prime}$ 'S, $47^{\circ} 16^{\prime} 40^{\prime \prime} \mathrm{W}$, 810 m, 27-III-2002, fl., G. Pereira-Silva et al. 6287 (CEN).

Táxon endêmico do Brasil com registro nas regiões Centro-Oeste (Distrito Federal, Goiás e Mato Grosso) e Sudeste (Minas Gerais e São Paulo) onde habita em campos limpos e rupestres e borda de matas (Kinoshita et al. 2007, Matsumoto \& Martins 2005, Flora do Brasil 2020). Foi encontrada em cerrado rupestre em ambiente encaichoeirado crescendo entre fendas ou sobre rochas com flores no mês de junho. Diferencia-se das demais estudadas e é reconhecida pelo hábito esguio com ramos quebradiços e pegajosos, incluindo folhas que são membranáceas, e flores com hipanto urceolado constrito na região mediana.

7. Microlicia insignis Schltdl, Linnaea 9(3): 750. 1835.

Figuras 10 a-j, 11 a-f

Subarbustos 0,45-1,2 m alt., eretos, não cespitosos. Ramos dicotômicos, corimbiformes, quando adultos cilíndricos, hirsutos e com cicatrizes foliares evidentes, quando jovens quadrangulares e com numerosas glândulas arredondadas. Folhas sésseis, não imbricadas; lâminas 3,5-9 × 1,4-4 mm, ovallanceoladas, cartáceas, base obtusa, margem inteira, ciliada, ápice acuminado, não pungente, 3-nérvias. Dicásios e ou flores solitárias. Flores $8-13 \mathrm{~mm}$ compr., 5-meras, pedicelo 1,6-2,2 mm compr.; hipanto 5-7 $\times$ 2,3-4 mm, finamente estriado, campanulado ou discretamente infundibuliforme, róseo-seríceo ou setoso-glanduloso externamente; lacínias do cálice 3,7-5,3 $\times 1,1-1,5 \mathrm{~mm}$, lanceoladas, inteiras, apiculadas com uma nervura calosa externamente; pétalas 6,5-8,3 $\times$ 3-5 mm, róseas, obovais, glabras, margem não ciliada, ápice oblíquo e mucronulado; estames 10, dimórficos, os antessépalos com filete 3-4,3 mm compr., conectivos com 3-5 mm de prolongamento, apêndices 1,2-2 mm compr., anteras 1,6-1,9 × 0,5-1 mm, amarelas e rostro 0,5-0,9 $\mathrm{mm}$ compr.; os antepétalos com filete $2,6-4 \mathrm{~mm}$ compr., conectivos com 1,1-1,8 mm de prolongamento, apêndices $0,5-0,8$ $\mathrm{mm}$ compr., anteras 1,3-1,7 $\times 0,5-0,7 \mathrm{~mm}$, amarelas, rostro $0,4-0,7 \mathrm{~mm}$ compr, ambos com filetes, anteras, prolongamentos dos conectivos e apêndices amarelos, estes últimos achatados e inteiros, e as anteras bi-tetraesporangiadas; ovário 1,8-3 × 1-2,3 mm, oblongoide, 3-locular, estilete 6,4-7,2 mm compr., róseo. Cápsulas 3,5-4,2 × 1,8-2,5 mm, oblongoides, marrons. Sementes 0,4-0,5 × 0,3-0,4 mm, oblongas, foveoladas, castanho-escuras.

Material examinado: Alto Paraíso de Goiás, trilha que leva ao Salto de $80 \mathrm{~m}, 1^{\circ} 09^{\prime} 49,8^{\prime \prime} \mathrm{S}, 47^{\circ} 49^{\prime} 55,5^{\prime \prime} \mathrm{W}$, 920 m, 13-III-2015, fl., D. O. Diniz et al. 78, 81 (UFG); margem esquerda da GO 118, de Alto Paraíso de Goiás a Teresina de Goiás, $13^{\circ} 59^{\prime} 8,0^{\prime \prime} \mathrm{S}, 47^{\circ} 30^{\prime} 28,9^{\prime \prime} \mathrm{W}$, 1525 m, 19-IV-2015, fl., fr., D.O. Diniz et al. 165, $166,173,174$ (UFG); posto vale da lua, $13^{\circ} 58^{\prime} 51,2^{\prime \prime S}$, $47^{\circ} 30^{\prime} 27,8^{\prime \prime} \mathrm{W}, 1519 \mathrm{~m}, 19-\mathrm{IV}-2015$, fl., fr., D.O. Diniz et al. 177, 184 (UFG); trilha que leva ao Salto de $80 \mathrm{~m}$ e $120 \mathrm{~m}, 1^{\circ} 09^{\prime} 49,9^{\prime \prime} \mathrm{S}, 47^{\circ} 49^{\prime} 55^{\prime \prime} \mathrm{W}, 930 \mathrm{~m}$, 2-V-2015, fl., D.O. Diniz et al. 234, 235, 237 (UFG); GO-239, $\mathrm{Km}$ 72, 500 metros da cerca para o interior 


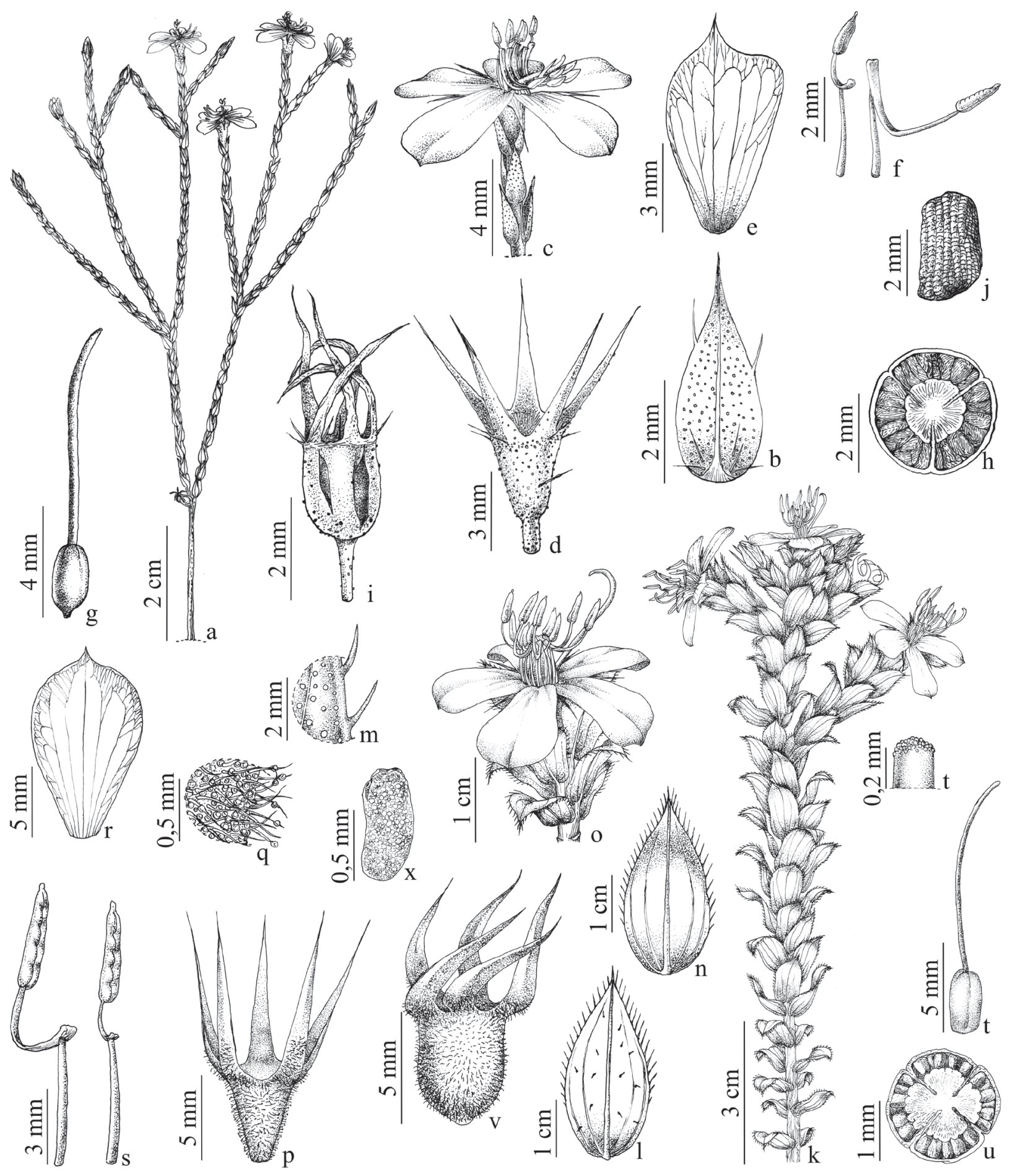

Figura 10. a-j. Microlicia insignis Schltdl. a. Hábito. b. Folha. c. Flor. d. Cálice. e. Pétala. f. Estames, antessépalo (direita), antepétalo (esquerda). g. Gineceu. h. Corte transversal do ovário. i. Cápsula. j. Semente. k-x. M. latifolia D.O. Diniz \& M.J. Silva. k. Ramo fértil. 1. Folha (face adaxial). m. Detalhe da margem foliar. n. Folha (face abaxial). o. Flor. p. Cálice. q. Detalhe do indumento do cálice. r. Pétala. s. Estames, antessépalo (esquerda), antepétalo (direita). t. Gineceu e detalhe do ápice do estilete. u. Corte transversal do ovário. v. Cápsula. x. Semente.

Figure 10. a-j. Microlicia insignis Schltdl. a. Habit. b.Leaf. c. Flower. d. Hypanthium and sepals. e. Petal. f. Larger stamen (right), Smaller stamen (left). g. Gynoecium. h. Cross section of ovary. i. Mature fruit wiyh hypanthium. j.Seed. k-x. M. latifolia D.O. Diniz \& M.J. Silva. k. Fertile branch. 1. Leaf, adaxial surfasse. m. Leaf margin detail. n. Leaf, abaxial surface. o. Flower. p. Hypanthium nad sepals. q. Hypanthium indument detail. r. Petal. s. Larger stamen (left), Smaller stamen (right). t. Gynoecium and detail of its apex. u. Cross section of ovary. v. Mature fruit with hypanthium. x. Seed. 

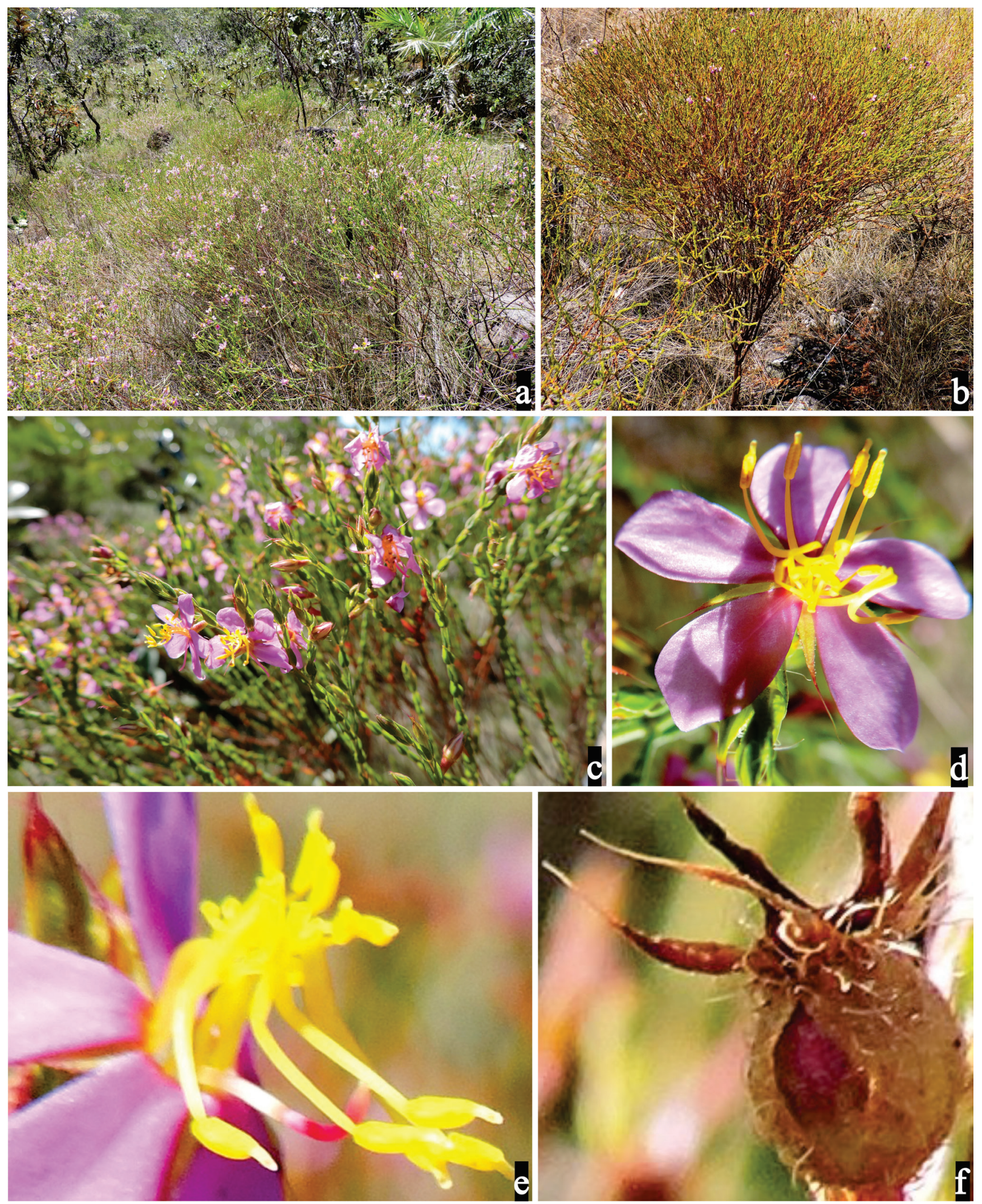

Figura 11. a-f. Microlicia insignis Schltdl. a. Habitat. b. Hábito. c. Ramo fértil. d. Flor. e. Androceu e gineceu. f. Cápsula.

Figure 11. a-f. Microlicia insignis Schltdl. a. Habitat. b. Habit. c. Fertile branch. d. Flower. e. Androecium and gynoecium. f. Mature fruit with hypanthium. 
do Parque, $14^{\circ} 08^{\prime} 18,6^{\prime \prime} \mathrm{S}, 47^{\circ} 44^{\prime} 8,8^{\prime \prime} \mathrm{W}, 1161 \mathrm{~m}$, 4-VI-2015, fl., D.O. Diniz et al. 361 (UFG); $1 \mathrm{Km}$ à partir do alojamento na lateral do primeiro morro em direção ao rio Preto, $14^{\circ} 9^{\prime} 35,4^{\prime \prime} \mathrm{S}, 47^{\circ} 47^{\prime} 36,4^{\prime \prime} \mathrm{W}$, 1074 m, 5-VI-2015, fl., D.O. Diniz et al. 364, 365 (UFG); morro do Japonês, $14^{\circ} 03^{\prime} 39^{\prime \prime} \mathrm{S}, 47^{\circ} 31^{\prime} 45,2^{\prime \prime} \mathrm{W}$, 1585 m, 3-VII-2015, fl., D.O. Diniz et al. 457, 458 (UFG); à $100 \mathrm{~m}$ do lado oposto do morro Chapado, $14^{\circ} 07^{\prime} 8,9^{\prime \prime} \mathrm{S}, 47^{\circ} 41^{\prime} 11,8^{\prime \prime} \mathrm{W}, 1190 \mathrm{~m}, 4-\mathrm{VII}-2015$, fr., D.O. Diniz et al. 476, 477 (UFG); entrada para Pouso

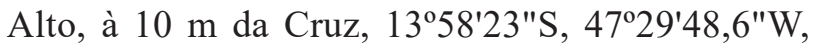
1008 m, 21-VIII-2015, fr., D.O. Diniz et al. 496 (UFG); entrada para Pouso Alto, após cadeia rochosa, após 3,5 Km da cruz do Pouso Alto, 135'ㄴ, 36 "S, 47³0'8,6"W, 1519 m, 22-VIII-2015, fr., D.O. Diniz et al. 534 (UFG); $1 \mathrm{~km}$ após rio Preto em direção ao morro Peito de Moça, 1402'56,5"S, 47038'21,4"W, 1203 m, 19-IX-2015, fl., fr., D.O. Diniz et al. 557 (UFG); à $7 \mathrm{Km}$ do morro do Japonês, à $20 \mathrm{Km}$ de Alto Paraíso na GO-118 em sentido Alto Paraíso à Teresina de Goiás, 13059'4,8"S, 47º30'32,5"W, $1495 \mathrm{~m}$, 29.VII.2016, fl., D.O. Diniz et al. 947, 981 (UFG). Cavalcante: após trilha que leva à sete quedas do rio Preto, após rio Preto, $14^{\circ} 05^{\prime} 44,5^{\prime \prime} \mathrm{S}, 47^{\circ} 45^{\prime} 1,6^{\prime \prime} \mathrm{W}$, 1071 m, 7-X-2015, fl., fr., D.O. Diniz et al. 636, 637 (UFG); final do Parque, 20.V.2016, fl., fr., D.O. Diniz et al. 900 (UFG), ib., fl., D. O. Diniz et al. 903 (UFG).

Material examinado adicional: BRASIL. GoIÁs: Alto Paraíso de Goiás, Chapada dos Veadeiros, em Água Fria, 29-VI-1997, fl., C. Munhoz et al. 452 (UB), ib., na estrada para a Vila São Jorge em campo limpo com afloramentos, 18-VI-1998, fl., $R$. Romero et al. 5570 (CEN), ib., na estrada de Alto Paraíso de Goiás para a Vila São Jorge ca. $3 \mathrm{Km}$ do Distrito São Jorge, 18-VI-1998, fl., F. Almeda et al. 7864 (BHCB, UB), ib., Chapada dos Veadeiros, em campo rupestre, 9-VI-1972, fl., J.A. Rizzo 8132 (UFG). Cavalcante:

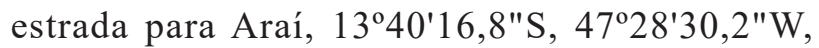
13-IV-2004, fl., M.L. Fonseca et al. 5041, 5043 (UB). Cocalzinho de Goiás: Serra dos Pireneus, 15²7'24"S, 48 52'50"W, 22-V-2013, fl., Versiane, A.F.A. \& Pacheco, R.A. 623 (UB). Colinas do Sul: Vila Borba, $14^{\circ} 07^{\prime} 36^{\prime \prime S}, 48^{\circ} 04^{\prime} 41^{\prime \prime W, ~ 23-V I-1999, ~ f l ., ~ B . M . T . ~}$ Walter et al. 4331 (UB). Pirenópolis: Parque Estadual da Serra dos Pireneus, 23-III-2003, fl., fr., Miranda et al. 42 (HUEG), ib., 15-VI-2003, fl., fr., Miranda et al. 114 (HUEG), ib., 15-VI-2003, fl., fr., Miranda et al. 170 (HUEG), ib., 10-VII-2003, fl., fr., Miranda et al. 289 (HUEG).
De acordo com BFG (2015) esta espécie é endêmica do Brasil e registrada para as regiões Centro-Oeste (Goiás, Mato Grosso e Mato Grosso do Sul), Nordeste (Maranhão) e Norte (Amazônia, Pará e Rondônia). Foi encontrada em campo úmido e cerrado rupestre sobre solos arenosos ou areno-argilosos com flores e frutos entre março e novembro.

Diferencia-se das demais estudadas por ser uma planta glabra com folhas muito acuminadas, cálice setoso-glanduloso e estames antessépalos com conectivo muito prolongado (3-5 $\mathrm{mm}$ compr.) e apêndices achatados e grandes (1,2-2 mm compr.). Pode ser confundida com M. acuminata e Microlicia veadeirana pela morfologia vegetativa, sendo as diferenças entre elas já comentadas na descrição das mesmas.

8. Microlicia latifolia D.O. Diniz \& M.J. Silva, J. Torrey Bot. Soc. 145(2): 176. 2018.

Figuras 10 k-x, 12 a-f

Arbustos 0,25-1,3 m. alt., eretos, não cespitosos. Ramos dicotômicos, não corimbiformes; quando adultos cilíndricos, decorticantes, glabros, cremealaranjados e com evidentes cicatrizes foliares, quando jovens quadrangulares, estrigosos e com numerosas glândulas arredondadas. Folhas sésseis, laxamente imbricadas; lâminas 1-4,3 × 0,4-2,5 cm, elípticas, ovalelípticas, oblongo-obovais, ou oblongas, cartáceas, curtamente estrigosas, base obtusa, margem inteira a discretamente crenada, ciliada, ápice acuminado, não pungente, 3-(-5)-nérvias. Flores 15-23 mm compr., 5, 6 ou 7-meras, pedicelo 1,6-2 mm compr.; hipanto 4-7,5 × 3,5-7 mm, infudibuliforme, curtamente hirsutos ou estrigosos e com glândulas sésseis externamente; lacínias do cálice 9,5-12 × 1,8-3 mm, lanceoladas, inteiras, aristadas, com discreta nervura calosa na face externa, semelhantes ao hipanto; pétalas 11,5-18 × 6,5-9 $\mathrm{mm}$, rosa pink ou purpúras, obovais e mucronuladas, glabras, margem não ciliada; estames 10, 12 ou 14, dimórficos, os antessépalos com filetes 4,2-6,2 mm compr., conectivos com 1,5-3,5 $\mathrm{mm}$ de prolongamento, apêndices $0,8-1,3 \mathrm{~mm}$ compr., anteras 2,8-4,6 × 0,8-1,2 mm, amarelas, rostro 0,3-1 mm compr.; os antepétalos com filetes 4,6-5,6 mm compr., conectivos com 1,4-2,2 mm de prolongamento, apêndices 0,6-0,8 $\mathrm{mm}$ compr., anteras 2,6-3,6 $\times 0,8-1 \mathrm{~mm}$, amarelas, rostro 0,4-0,6 mm compr, ambos com filetes, anteras, prolongamentos dos conectivos e apêndices amarelos, estes últimos achatados inteiros ou bilobados e anteras 


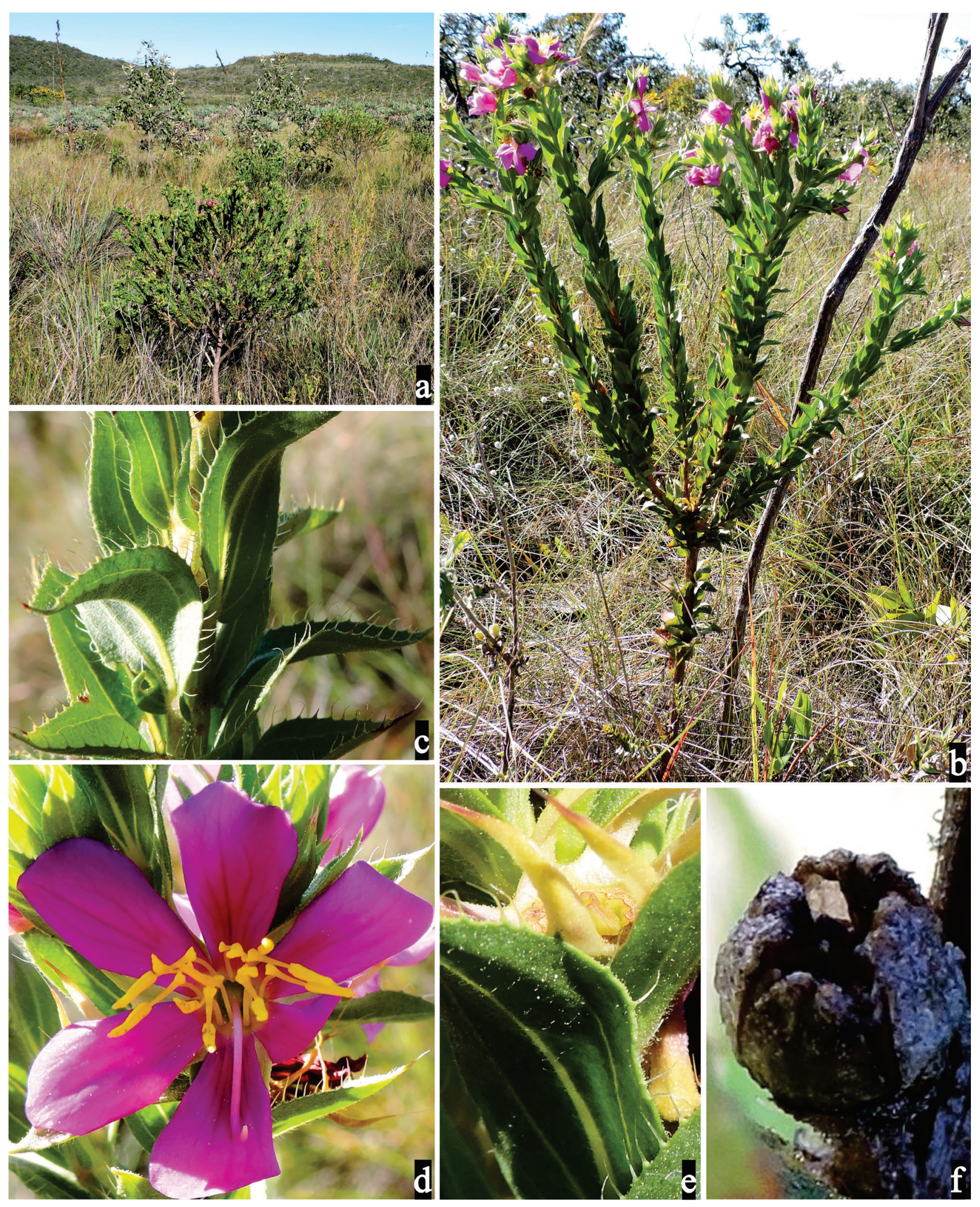

Figura 12. a-f. Microlicia latifolia D.O. Diniz \& M.J. Silva. a. Habitat. b. Hábito. c. Ramo folhoso. d. Flor. e. Cápsula com hipanto persistente. f. Deiscência da cápsula.

Figure 12. a-f. Microlicia latifolia D.O. Diniz \& M.J. Silva. a. Habitat. b. Habit. c. Leafy branch. d. Flower. e. Mature fruit with hypanthium. f. Capsule dehiscence. 
poliesporangiadas; ovário 4-5,3 × 2-3 $\mathrm{mm}$, oblongoide 4-(5)locular, estilete 9,7-12,6 mm compr., róseo. Cápsulas 5-12 × 3-5 mm, globosas, verde-amareladas ou marrons. Sementes $0,5-0,7 \times 0,25-0,45 \mathrm{~mm}$, oblongas, cinzas ou castanhas.

Material examinado: Alto Paraíso de Goiás: à 300 metros à esquerda do alojamento principal do Parque, $14^{\circ} 9^{\prime} 34^{\prime \prime S}, 47^{\circ} 47^{\prime} 36^{\prime \prime} \mathrm{W}, 1070 \mathrm{~m}, 5-\mathrm{VI}-2015$, fl., M.J. Silva et al. 6720 (parátipo), 6721 (holótipo) (UFG); à 400 metros atrás do alojamento principal do Parque, 14'9'32,3"S, 4707'34,8"W, 1078 m, 21-V-2016, fl., D.O. Diniz \& R.N. Ribeiro 913, 914, 915, 916, 917, 918, 919, 920, 921 (parátipos) (UFG); ib., fr., D.O. Diniz \& R.N. Ribeiro 923 (parátipo) (UFG); à $1 \mathrm{~km}$ da antena do alojamento do lobo guará, $14^{\circ} 9^{\prime} 12,3^{\prime \prime} \mathrm{S}$, 47047'19,2"W, 1094 m, 21-V-2016, fl., D.O. Diniz \& R.N. Ribeiro 930 (parátipo) (UFG); à 260 metros noroeste dos alojamentos, $14^{\circ} 9^{\prime} 32,9^{\prime \prime} \mathrm{S}, 47^{\circ} 49^{\prime} 44,7^{\prime \prime} \mathrm{W}$, 1068 m, 20-VIII-2016, fr., D.O. Diniz et al. 1066 (parátipo) (UFG).

Microlicia latifolia foi descoberta durante este estudo, recentemente publicada (D.O. Diniz \& M.J. Silva 2018). Foi coletada em campos limpos ou sujos sobre solos argilosos entre 1070 e 1078 metros de altitude com flores e frutos de maio a junho. Se destaca dentre as congêneres pelas folhas laxamente imbricadas, grandes e largas 1-4,3 $\times 0,4-2,5 \mathrm{~cm}$, elípticas, oval-elípticas ou oblongas com margem ciliada e conspícuas glândulas em ambas as faces, bem como pelas flores vistosas com 5,6 ou 7 pétalas rosa pink ou púrpuras, cálice com lacínias longas (ca. $12 \mathrm{~mm}$ compr.) e apiculadas e androceu com 10, 12 ou 14 estames amarelos, sendo os conectivos dos antessépalos prolongados até $3,5 \mathrm{~mm}$ compr.

9. Microlicia melanostagma Pilg., Bot. Jahrb. Syst. 33: 18. 1903.

Figuras 13 a-1, 14 a-f

Subarbustos 35-90 cm alt., eretos, com ramos pendentes, não cespitosos. Ramos dicotômico ou tricotômico próximo ao ápice, não corimbiformes, quadrangulares, glabros e com glândulas arredondadas, quando adultos decorticantes. Folhas sésseis, não imbricadas; lâminas 3,8-6,3 × 1,7-5,3 mm, ovais, cartáceas, base cordada, margem serreada e longamente ciliado-glandular, ápice acuminado, não pungente, 3-5-nérvias, glabras, com esparsos tricomas longamente hispido-glandulares na face abaxial. Flores 8-12 mm compr., 5-meras, pedicelo 1-2,2 mm compr.; hipanto $2-2,7 \times 1,8-2,5 \mathrm{~mm}$, campanulado, não costado, glabro; lacínias do cálice 3,2-3,7 × 0,8-1,1 mm, lanceoladas, ciliado-glandulares, acuminadas e longamente híspido-glandulares na base; pétalas 6,8-10×4,5-6,5 mm, rosa pink com lilás, obovais, glabras, margem não ciliada, ápice retuso e mucronulado; estames 10, dimórficos, os antessépalos com filetes 2,6-3,6 mm compr., conectivos com 1-1,6 $\mathrm{mm}$ de prolongamento, apêndices $0,8-1,5 \mathrm{~mm}$ compr., bilobados, anteras 1,2-1,5 $\times 0,5-0,8 \mathrm{~mm}$, róseas, rostro $0,8-1,4 \mathrm{~mm}$ compr.; os antepétalos com filetes 2,8-3,2 mm compr., conectivos 0,5$0,7 \mathrm{~mm}$ de prolongamento, apêndices $0,1-0,3$ $\mathrm{mm}$ compr., inteiros, anteras 1-1,3 × 0,3-0,6 mm, amarelas, rostro 0,2-0,4 $\mathrm{mm}$ compr., ambos com filetes róseo-amarelados, prolongamentos dos conectivos e apêndices amarelos, estes últimos achatados, e anteras bi-tetraesporangiadas; ovário 2,4-2,7 × 0,9-1,2 mm, globoso, 3-locular, estilete 1,8-2,3 mm compr., amarelo ou róseo-amarelado. Cápsulas 2-5,2 × 1,9-3,5 mm, globosas, verdeamarronzadas. Sementes 0,6-1,2 × 0,3-0,5 mm, oblongas, douradas.

Material examinado: Alto Paraíso de Goiás, na região da Cachoeira das 7 Quedas do rio Preto, $14^{\circ} 06^{\prime} 53,2^{\prime \prime S}$, $47^{\circ} 44^{\prime} 23,8^{\prime \prime} \mathrm{W}, 1088 \mathrm{~m}, 15-\mathrm{II}-2015$, fl., fr. D.O. Diniz et al. 47, 48, 49, 50 (UFG); ib., 14º6'18,6"S, $47^{\circ} 44^{\prime} 11,5^{\prime \prime} \mathrm{W}, 1135 \mathrm{~m}, 15-\mathrm{II}-2015$, fl., fr. D.O. Diniz et al. 32, 34 (UFG); trilha oposta que leva às 7 quedas do rio Preto, $14^{\circ} 06^{\prime} 02^{\prime \prime} \mathrm{S}, 47^{\circ} 44^{\prime} 24,1^{\prime \prime} \mathrm{W}$, 1106 m, 15-II-2015, fl., fr. D.O. Diniz et al. 43, 44 (UFG); área lateral ao Morro da Baleia, $14^{\circ} 07^{\prime} 20,8^{\prime \prime} \mathrm{S}$, 47³9'59,2"W, 1234 m, 20-IV-2015, fl., fr. D.O. Diniz et al. 208 (UFG); morro Chapado, 1409'56,7"S, 47050'29,2"W, 859 m, 26-II-2016, fl., D.O. Diniz et al. 800 (UFG), ib., fl., fr., D.O. Diniz et al. 801, 802, $803,804,805,806$ (UFG); trilha para as sete quedas do rio Preto, 28-X-2016, $14^{\circ} 06^{\prime} 48,9^{\prime \prime} \mathrm{S}, 47^{\circ} 44^{\prime} 51,1^{\prime \prime} \mathrm{W}$, 1213 m, fl., D.O. Diniz et al. 1124, 1125, 1130 (UFG); em vereda, dentro do parque, $14^{\circ} 07^{\prime} 44^{\prime \prime} \mathrm{S}, 47^{\circ} 41^{\prime} 12^{\prime \prime} \mathrm{W}$, sd, fr., Munhoz, C.B.R. et al. 7841 (UB, HUFU).

Material examinado adicional: BRASIL. DistrITO FEDERAL: Brasília, sobradinho no campo, 22-XI-1894, fl., Glaziou 21263 (BHCB). Goiśs: Alto Paraíso de Goiás, $2^{\mathrm{a}}$ ponte à esquerda, 24-I-1997, fl., M.C. Assis et al. 350 (CEN); Saia Velha, coletada em cerrado, 15-II-1965, fl., E.P. Heringer 10083 (UB).

Microlicia melanostagma é registrada no Estado Goiás e no Distrito Federal (Flora do Brasil 2020). Foi coletada em cerrado ralo e típico e em campo úmido 


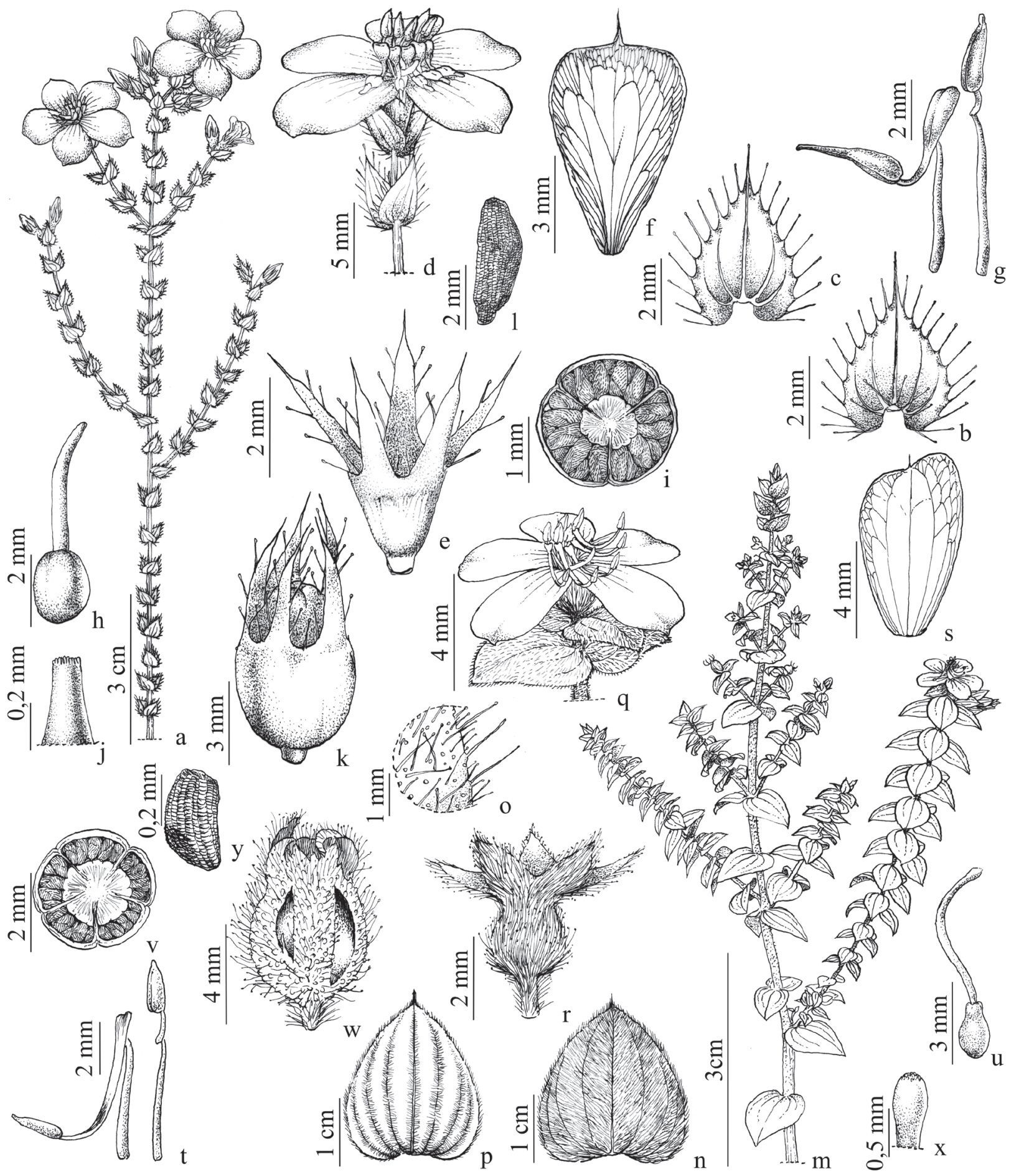

Figura 13. a-1. Microlicia melanostagma Pilg. a. Hábito. b. Folha (face adaxial). c. Folha (face abaxial). d. Flor. e. Cálice. f. Pétala. g. Estames, antessépalo (esquerda), antepétalo (direita). h. Gineceu. i. Corte transversal do ovário. j. Detalhe do ápice do estilete. k. Cápsula. 1. Semente. m-y. M. ordinata (Wurdack) Almeda \& A.B. Martins. m. Hábito. n. Folha (face adaxial). o. Detalhe do indumento da lâmina. p. Folha (face abaxial). q. Flor. r. Cálice. s. Pétala. t. Estames, antessépalo (esquerda), antepétalo (direita). u. Gineceu. v. Corte transversal do ovário. x. Detalhe do ápice do estilete. w. Cápsula. y. Semente.

Figure 13. a-1. Microlicia melanostagma Pilg. a. Habit. b. Leaf, adaxial surface. c. Leaf, abaxial surface. d. Flower. e. Hypanthium and sepals. f. Petal. g. Larger stamen (left), smaller stamen (right). h. Gynoecium. i. Cross section of ovary. j. Apex of stigma. k. Mature fruit with hypanthium. 1. Seed. m-y. M. ordinata (Wurdack) Almeda \& A.B. Martins. m. Habit. n. Leaf, adaxial surface. o. Leaf indumento detail. p. Leaf, abaxial surface. q. Flower. r. Hypanthium and sepals. s. Petal. t. Larger stamen (left), smaller stamen (right). u. Gynoecium. v. Cross section of ovary. x. Detail of its apex. w. Mature fruit with hypanthium. y. Seed. 


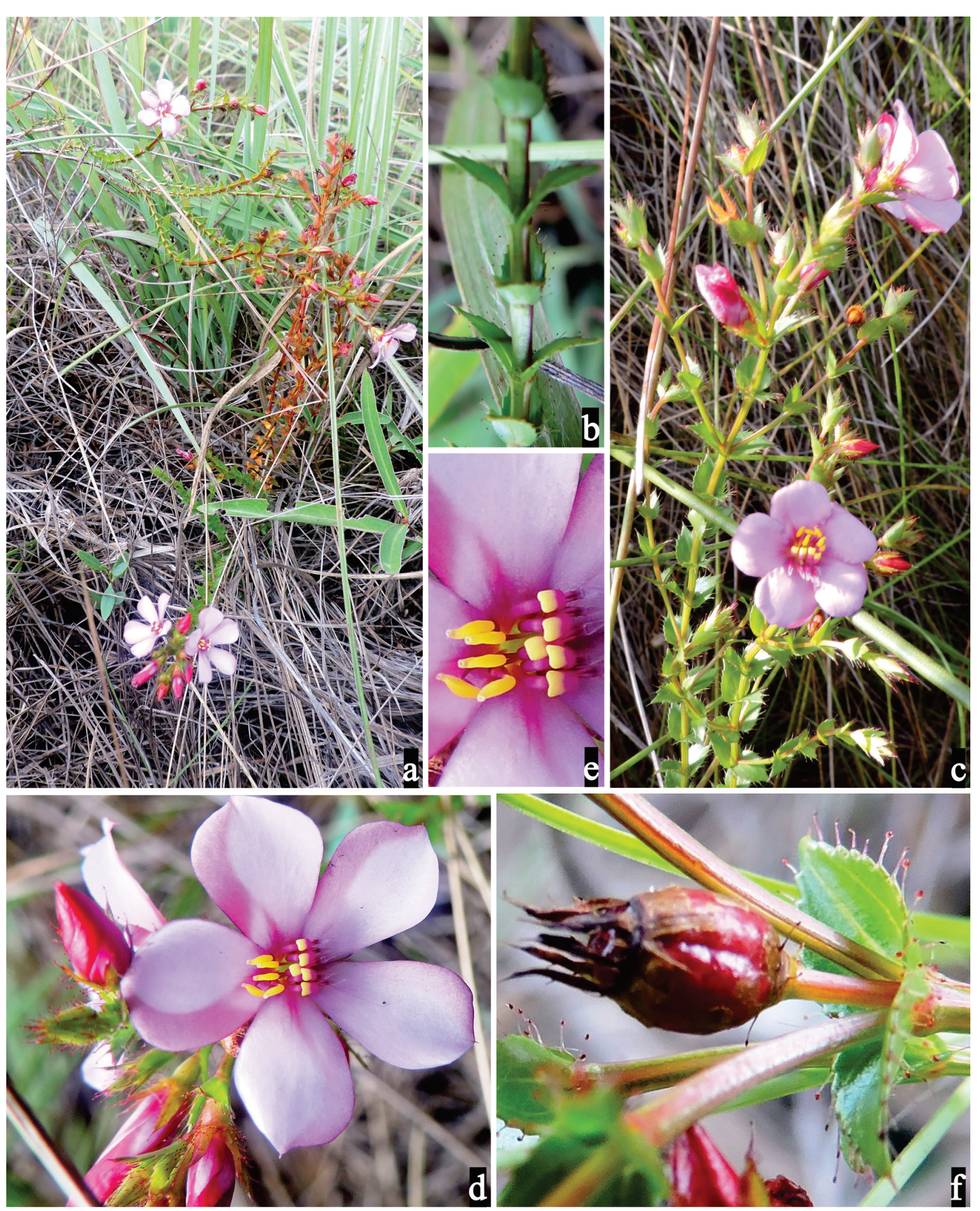

Figura 14. a-f. Microlicia melanostagma Pilg. a. Hábito. b. Ramo folhoso. c. Ramo fértil. d. Flor. e. Androceu. f. Cápsula.

Figure 14. a-f. Microlicia melanostagma Pilg. a. Habit. b. Leafy branch. c. Fertile branch. d. Flower. e. Androecium. f. Mature fruit with hypanthium. 
próximo à córregos com flores e frutos nos meses de fevereiro e abril. Relaciona-se morfologicamente com $M$. viminalis pelas folhas sem glândulas e ramos muitas vezes pendentes. Entretanto, distingue-se desta pelas folhas cartáceas, não imbricadas nem pungentes com margens serreadas e com longos tricomas róseoglandulares e flores $0,8-1,2 \mathrm{~cm}$ de compr. e com hipanto glabro. Microlicia viminalis apresenta folhas coriáceas, imbricadas, pungentes com margem ciliada, mas raramente glandular e, flores 1,5-2,7 cm compr. o hipanto com tricomas glandulares.

10. Microlicia ordinata (Wurdack) Almeda \& A.B.Martins, Novon 11(1): 5. 2001.

Lavoisiera ordinata Wurdack, Phytologia 29(2): 135-136. 1974.

Figuras 13 m-y, 15 a-d

Subarbustos 0,35-1 m alt., eretos, não cespitosos. Ramos dicotômicos, não corimbiformes, quando adultos cilíndricos a quadrangulares, decorticantes e glabrecentes, quando jovens quadrangulares, hirsutos e com glândulas punctiformes. Folhas sésseis, não imbricadas; lâminas 7-21 × 3,8-15 mm, largamente ovais, cartáceas, base subcordada, margem inteira a discretamente serreada, ciliado-glandular, ápice obtuso, não pungente, 5-7-nérvias, com glândulas punctiformes e curtamente seríceas em ambas as faces, os tricomas mais adensados na face adaxial. Dicásios e, ou flores solitárias, em ramos curtos, terminais. Flores 10-15 mm compr., 5-meras, pedicelo 0,7-2 mm compr.; hipanto 4-7,2 × 3,7-5 mm, urceolado, com glândulas arredondadas e tricomas seríceos e ou hirsuto-glandulares externamente; lacínias do cálice 1,9-4 × 1,3-2 $\mathrm{mm}$, triangulares, margem inteira ou discretamente crenada e ciliada, apiculadas, semelhantes ao hipanto; pétalas 6,9-10,3 × 4-6,5 mm, rosa pink, rosa claro ou brancas, obovais, glabras, ápice oblíquo e mucronulado-glandular, margem não ciliada; estames 10 , dimórficos, os antessépalos com filetes 4-6,2 mm compr., conectivos com 4-5,2 $\mathrm{mm}$ de prolongamento, apêndices 1-1,4 mm compr., achatados, róseos-amarelados, anteras 1,8-2,4 × 0,9-1,2 mm, vináceas, rostro $0,4-0,8 \mathrm{~mm}$ compr.; os antepétalos com filetes 3,7-5,3 mm compr., conectivos com 0,5-1 mm de prolongamento, apêndices 0,1-0,3 mm compr., tuberculados, bilobados e róseos, anteras 1,4-2 × 0,5-1,2 mm, amarelas, rostro 0,4-0,8 $\mathrm{mm}$ compr., ambos com filetes e prolongamento dos conectivos róseos, apêndices amarelos e anteras bi ou poliesporangiadas; ovário 2,1-3,5 × 1-2,2 mm, ovoide, 5-locular, estilete 5,5-7 mm compr. Cápsulas 4,8-8 $\times$ 4-5,3 mm, piriformes, douradas ou marrons. Sementes 0,5-1,2 × 0,2-0,4 mm, oblongas, douradas ou marrons.

Material examinado: Alto Paraíso de Goiás: Morro do Japonês, $14^{\circ} 03^{\prime} 28,8^{\prime \prime} \mathrm{S}, 4^{\circ} 32^{\prime} 8,3^{\prime \prime} \mathrm{W}, 1516 \mathrm{~m}$, 14-III-2015, fl., D.O. Diniz et al. 133, 139, 142, 145, 146, 147, 149 (UFG), ib., 1403'39"S, 47³1'45,2"W, 1585 m, 3-VII-2015, fl., fr., D.O. Diniz et al. 453, 454 (UFG); próximo ao Morro do Japonês, $14^{\circ} 03^{\prime} 17,8^{\prime \prime} \mathrm{S}$, 47³2'8,3"W, 1554 m, 3-V-2015, fl., D.O. Diniz et al. 295 (UFG); A nordeste do alojamento, ca. 200 metros do rio Preto, $14^{\circ} 08^{\prime} 35^{\prime \prime} \mathrm{S}, 47^{\circ} 47^{\prime} 38^{\prime \prime} \mathrm{W}$, 1003 m, 5-VI-2015, fl., fr. D.O. Diniz et al. 394 (UFG), ib., 1356'27,7"S, 47³0'2,9"W, $1497 \mathrm{~m}$, 22-VIII-2015, fr., D.O. Diniz et al. 531 (UFG); trilha que leva à Cachoeira das Sete Quedas, $14^{\circ} 06^{\prime} 35,6^{\prime \prime} \mathrm{S}$, 47044'54,5"W, 1181 m, 20-IX-2015, fr., D.O. Diniz et al. 577, 578, 579, 580, 584, 585, 586, 587, 598 (UFG); ib., 14 $04^{\circ} 35,1^{\prime \prime S}, 47^{\circ} 44^{\prime} 55,3^{\prime \prime} \mathrm{W}, 1175 \mathrm{~m}$, 7-X-2015, fr., D.O. Diniz et al. 615, 616, 617, 618 (UFG); parada à $6 \mathrm{Km}$ de Alto Paraíso de Goiás, $500 \mathrm{~m}$ de dentro do parque, $14^{\circ} 5^{\prime} 12,1^{\prime \prime S}, 4^{\circ} 31^{\prime} 28,4^{\prime \prime} \mathrm{W}$, 1366 m, 19-VIII-2016, fr., D.O. Diniz et al. 1062 (UFG); à $260 \mathrm{~m}$ noroeste dos alojamentos do parque, 1409'32,9"S, 4749'44,7"W, 1068 m, 20-VIII-2016, fr., D.O. Diniz et al. 1071 (UFG); Cavalcante: final do parque, sentido Teresina de Goiás, ca. $150 \mathrm{~m}$ à partir da estrada, $13^{\circ} 55^{\prime} 7,3^{\prime \prime} \mathrm{S}, 47^{\circ} 25^{\prime} 28,2^{\prime \prime} \mathrm{W}, 1421 \mathrm{~m}$, 20-XI-2015, fl., fr., D.O. Diniz et al. 673 (UFG); final do parque, sentido Teresina de Goiás, ca. $500 \mathrm{~m}$ à partir da estrada, $13^{\circ} 55^{\prime} 14,9^{\prime \prime} \mathrm{S}, 47^{\circ} 26^{\prime} 7,4^{\prime \prime} \mathrm{W}, 1463 \mathrm{~m}$, 20-XI-2015, fr., D.O. Diniz et al. 689 (UFG).

Material examinado adicional: BRASIL. GoIÁs: Alto Paraíso de Goiás, Chapada dos Veadeiros, $20 \mathrm{Km}$ de Alto Paraíso de Goiás, 5-III-1973, fl., W.R. Anderson 6381 (UB), ib., 7 Km de Alto Paraíso para Terezina de Goiás, 21-V-1994, fl., C. Munhoz et al. 91 (UB).

Espécie endêmica do Estado de Goiás e registrada para a Chapada dos Veadeiros e Serra Dourada (Machado 2003). Coletada em cerrado rupestre e campos úmidos sobre solos arenosos, argilo-arenosos ou próximo a fendas de rochas entre 1003 e $1554 \mathrm{~m}$ de altitude com flores e frutos em março, e entre maio e novembro.

Relaciona-se morfologicamente com $M$. ramosa pelo aspecto de ramificação do caule, distribuição das flores ao longo dos ramos e forma das folhas. Porém, 


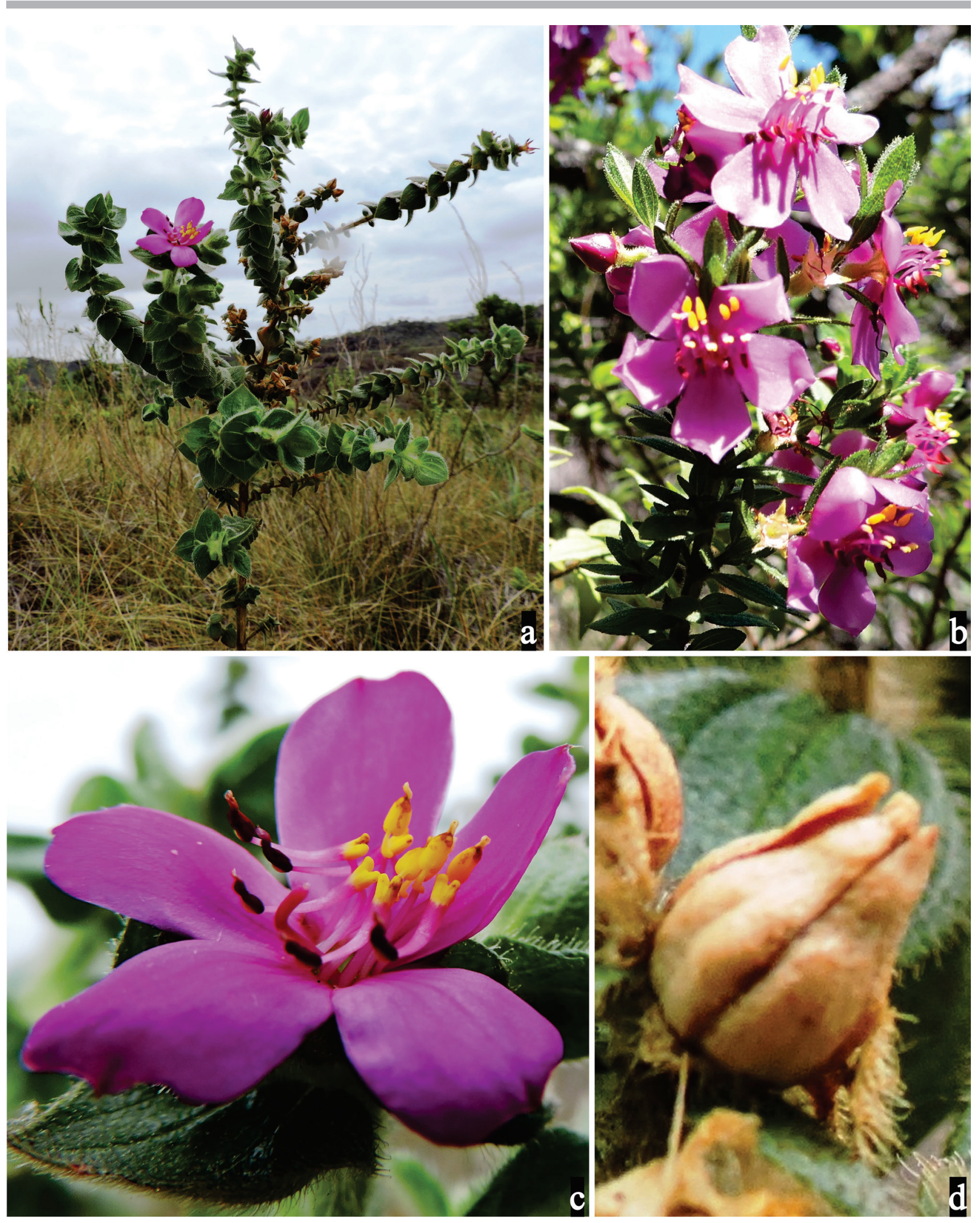

Figura 15. a-d. Microlicia ordinata (Wurdack) Almeda \& A.B. Martins. a. Hábito. b. Ramo fértil. c. Flor. d. Cápsula.

Figure 15. a-d. Microlicia ordinata (Wurdack) Almeda \& A.B. Martins. a. Habit. b. Fertile branch. c. Flower. d. Mature fruit with hypanthium. 
M. ordinata apresenta folhas 5-7-nérvias, curtamente seríceas na face abaxial e estrigosas na abaxial, ambos os tricomas secretores, lacínias do cálice com glândulas punctiformes externamente, anteras dos estames antessépalos vináceas e ovário 5-locular, paradoxalmente a $M$. ramosa onde as folhas são 3-nérvias, pubescente-glandulares em ambas as faces, as lacínias do cálice possuem glândulas punctiformes em ambas as faces, as anteras dos estames antessépalos são róseas e o ovário é 4(5)-locular.

11. Microlicia psammophila Wurdack, Los Angeles County Mus. Contr. Sci. 28: 4. 1959.

Figuras $16 \mathrm{a}-\mathrm{k}, 17 \mathrm{a}-\mathrm{f}$

Subarbustos $10-70 \mathrm{~cm}$ alt., eretos, cespitosos ou não. Ramos dicotômicos, não corimbiformes, quando adultos cilíndricos e esfoliantes, quando jovens quadrangulares, ambos glabros. Folhas sésseis, não imbricadas; lâminas 3,2-6 × 0,7-1,2 mm, lanceoladas, cartáceas, base truncada, margem inteira, ápice aristado, não pungente, 1-nérvias, com glândulas arredondadas, porém estas mais evidentes na face abaxial. Flores 9-13 mm compr., solitárias, 5-meras, sésseis ou com pedicelo $0,1-0,3 \mathrm{~mm}$ compr.; hipanto 2,8-4 × 2,4-3 mm, campanulado, glabro, com ou sem glândulas externamente; lacínias do cálice 3-5 × 1-2 mm, lanceoladas, inteiras com glândulas brancas na margem e pubescente-glandulares com glândulas róseas internamente; pétalas $7-11,3 \times 4,3-8,3 \mathrm{~mm}$, rosa pink com ou sem base amarelada, obovais, glabras, ápice obtuso e aristado, margem não ciliada; estames 10 , subisomórficos, os antessépalos com filetes 3-4,6 mm compr., conectivos com 0,7-1,3 $\mathrm{mm}$ de prolongamento, apêndices $0,2-0,3 \mathrm{~mm}$ compr., anteras $1,7-3 \times 0,8-1,3 \mathrm{~mm}$, amarelas, rostro 1-1,7 mm compr.; os antepétalos com filetes 2,4-4 mm compr., conectivos com 0,6-1,1 mm de prolongamento, apêndices $0,1-0,2 \mathrm{~mm}$ compr., anteras 1,6-2,6 $\times$ 0,7-1,1 mm, amarelas, rostro 0,5-1,5 mm compr., ambos com filetes, conectivos, apêndices achatados e anteras biesporangiadas amarelas; Ovário 2,1-3 × 1,1-2,2 mm, elipsoide, 3-locular, estilete 6,5-10 mm compr., róseo-amarelado. Cápsulas 3,5-5,5 × 2-4,2 mm, globosas, semelhantes ao hipanto, marrons ou avermelhadas. Sementes 0,4-0,7 $\times 0,3-0,5 \mathrm{~mm}$, oblongas, douradas ou marrons.

Material examinado: Alto Paraíso de Goiás: Trilha que leva ao Salto de $80 \mathrm{~m}, 1^{\circ} 09^{\prime} 50,8^{\prime \prime} \mathrm{S}, 47^{\circ} 50^{\prime} 4,6^{\prime \prime} \mathrm{W}$, 899 m, 13-III-2015, fl., D.O. Diniz et al. 85, 87 (UFG); Margem esquerda da GO-118 de Alto Paraíso de Goiás para Teresina de Goiás, $13^{\circ} 59^{\prime} 2,8^{\prime \prime} \mathrm{S}, 47^{\circ} 30^{\prime} 44,8^{\prime \prime} \mathrm{W}$, 1467 m, 19-IV-2015, fl., fr., D.O. Diniz et al. 175 (UFG); Área lateral ao Morro da Baleia, $14^{\circ} 07^{\prime} 18,1^{\prime \prime S}$, 47³9'53,7"W, 1221 m, 20-IV-2015, fl., D.O. Diniz et al. 213, 214, 215, 216 (UFG); Trilha que leva ao Salto de 80 e $120 \mathrm{~m}, 14^{\circ} 09^{\prime} 49,9^{\prime \prime} \mathrm{S}, 4^{\circ} 49^{\prime} 55^{\prime \prime} \mathrm{W}, 930 \mathrm{~m}$, 2-V-2015, fl., fr. D.O. Diniz et al. 240, 241 (UFG); ib. $14^{\circ} 10^{\prime} 2,8^{\prime \prime} \mathrm{S}, 47^{\circ} 50^{\prime} 46,9^{\prime \prime} \mathrm{W}, 793 \mathrm{~m}, 2-\mathrm{V}-2015$, fl., fr. D.O. Diniz et al. 248, 249, 250 (UFG); Trilha oposta aos alojamentos do parque, rumo aos cânions, $14^{\circ} 09^{\prime} 38,5^{\prime \prime S}, 47^{\circ} 47^{\prime} 44,1 " \mathrm{~W}, 1078$ m, 3-V-2015, fl., D.O. Diniz et al. 306, 307, 308, 316, 319 (UFG); GO-239, Km 72, à $500 \mathrm{~m}$ para dentro do Parque., $14^{\circ} 08^{\prime} 18,6^{\prime \prime S}, 47^{\circ} 44^{\prime} 8,8^{\prime \prime} \mathrm{W}, 1161 \mathrm{~m}, 4-\mathrm{VI}-2015$, fl., D.O. Diniz et al. 336, 337, 338, 339, 340 (UFG); alto do Morro Chapado, $14^{\circ} 07^{\prime} 23,9^{\prime \prime} \mathrm{S}, 47^{\circ} 41^{\prime} 16,5^{\prime \prime} \mathrm{W}, 1263 \mathrm{~m}$, 4-VII-2015, fl., fr., D.O. Diniz et al. 469, 470 (UFG); vereda ao lado do morro Chapado, $14^{\circ} 07^{\prime} 12,6^{\prime \prime S}$, $47^{\circ} 41^{\prime} 45,7^{\prime \prime} \mathrm{W}, 1187$ m, 4-VII-2015, fl., fr., D.O. Diniz et al. 479, 480, 481 (UFG); estrada à $7 \mathrm{Km}$ do morro da Baleia, sentido rio Preto, $14^{\circ} 03^{\prime} 54,6^{\prime \prime} \mathrm{S}, 47^{\circ} 38^{\prime} 17,6^{\prime \prime} \mathrm{W}$, 1193 m, 19-IX-2015, fr., D.O. Diniz et al. 571 (UFG); entrada para o alojamento dos brigadistas, $14^{\circ} 10^{\prime} 1,1^{\prime \prime S}$, 47²7'37,1"W, 1463 m, 20-XI-2015, fr., D.O. Diniz et al. 699 (UFG); trilha para as sete quedas do rio Preto, 28-X-2016, 14º6'48,9"S, 4704'51,1"W, $1213 \mathrm{~m}$, fl., D.O. Diniz et al. 1122, 1123 (UFG). Cavalcante: Limite final do Parque, $13^{\circ} 55^{\prime} 18,5^{\prime \prime} \mathrm{S}, 4^{\circ} 25^{\prime} 21^{\prime \prime} \mathrm{W}$, 1519 m, 19-IV-2015, fl., D.O. Diniz et al. 186 (UFG); ib., 20-V-2016, fr., D.O. Diniz et al. 910 (UFG).

Material examinado adicional: BRASIL. GoIÁs: Alto Paraíso de Goiás, Chapada dos Veadeiros, ca. $18 \mathrm{Km}$ de Alto Paraíso de Goiás, 21-III-1971, fl., fr., H.S. Irwin et al. 32863 (UB), ib., Chico preto, 28-VI-1997, fl., C. Munhoz et al. 440 (UB), ib., $15 \mathrm{Km}$ de Alto Paraíso em direção à Teresina de Goiás, 23-V-1994, fr., C. Munhoz et al. 145 (UB); Teresina de Goiás, Chapada dos Veadeiros, $24 \mathrm{Km} \mathrm{S}$ de Teresina em cerrado, 16-III-1963, fl., Anderson, W. R. et al. 7211 (UB); Cachoeira dos Cristais, 22-V-2008, J.M. Silva et al. 6626 (HUFU); próximo ao Vale da Lua, $13^{\circ} 58^{\prime} 51,2^{\prime \prime S}, 47^{\circ} 30 ' 27,8^{\prime \prime} \mathrm{W}, 1519$ m, 19-IV-2015, fl., D.O. Diniz et al. 180 (UFG), ib., fl., fr., D.O. Diniz et al. 181, 182 (UFG).

Espécie endêmica da Chapada dos Veadeiros (Flora do Brasil 2020). No PNCV é comumente encontrada em cerrados típico, ralos e rupestres e em campos, em locais úmidos, sobre solos arenosos, argilo-arenosos ou fendas de rochas entre 793-1519 metros de altitude, coletada com flores de março a 


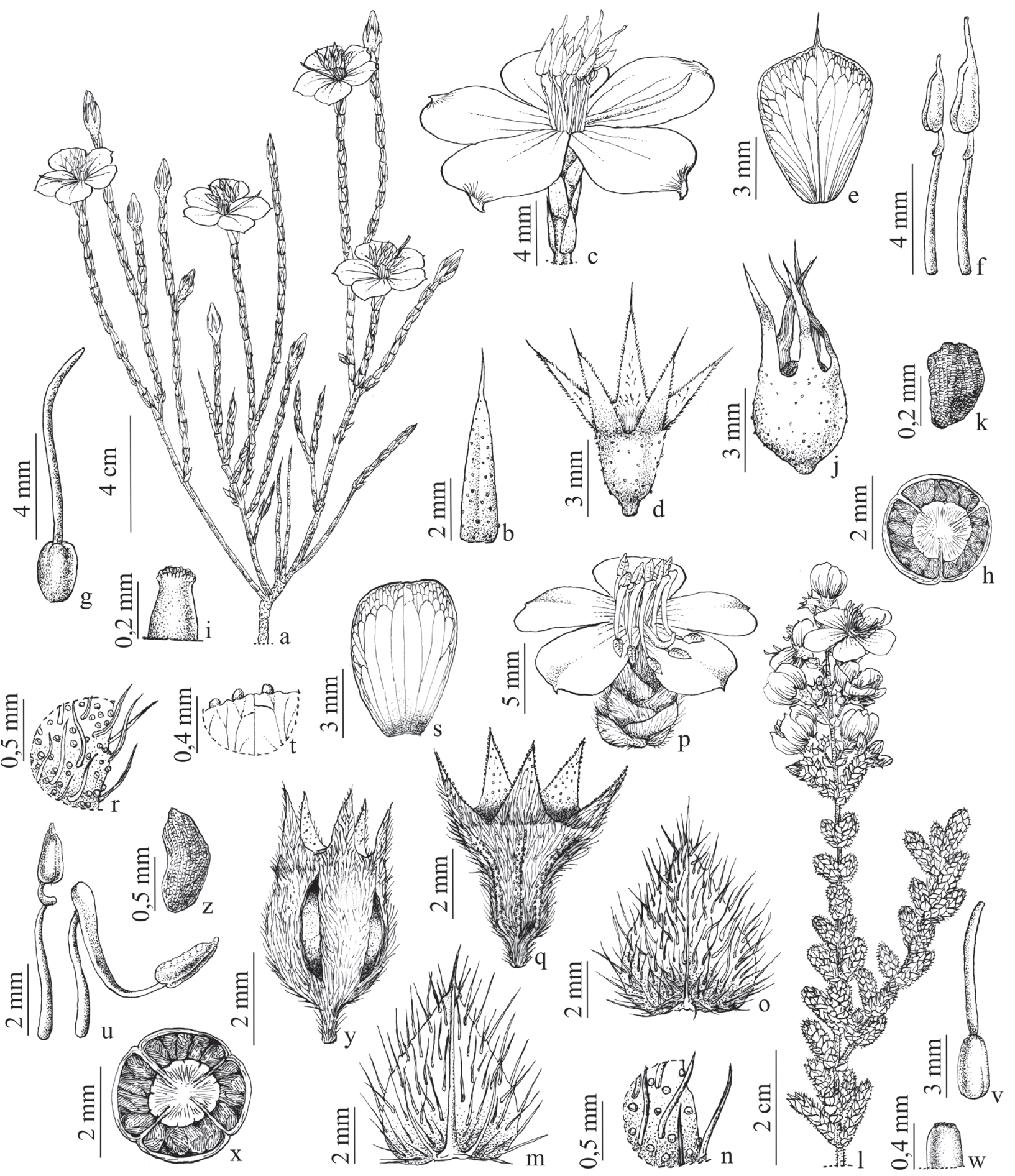

Figura 16. a-k. Microlicia psammophila Wurdack. a. Hábito. b. Folha. c. Flor. d. Cálice. e. Pétala. f. Estames, antessépalo (direita), antepétalo (esquerda). g. Gineceu. h. Corte transversal do ovário. i. Detalhe do ápice do estilete. j. Cápsula. k. Semente. 1-z. M. ramosa Pilg. 1. Hábito. m. Folha (face adaxial). n. Detalhe do indumento da folha. o. Folha (Face abaxial). p. Flor. q. Cálice. r. Detalhe do indumento do cálice. s. Pétala. t. detalhe do ápice da pétala. u. Estames, antessépalo (direita), antepétalo (esquerda). v. Gineceu. x. Corte transversal do ovário. w. Detalhe do ápice do estilete. y. Cápsula. z. Semente.

Figure 16. a-k. Microlicia psammophila Wurdack. a. Habit. b. Leaf. c. Flower. d. Hypanthium. e. Petal. f. Larger stamen (right), smaller stamen (left). g. Gynoecium. h. Cross section of ovary. i. Apex of stigma. j. Mature fruit with hypanthium. k. Seed. 1-z. M. ramosa Pilg. 1. Habit. m. Leaf, adaxial surface. n. Leaf indument detail. o. Leaf, abaxial surface. p. Flower. q. Hypanthium and sepals. r. Hypanthium indument detail. s. Petal. t. Petal apex detail. u. Larger stamen (right), smaller stamen (left). v. Gynoecium. x. Cross section of ovary. w. Apex of stigma. y. Mature fruit with hypanthium. z. Seed. 

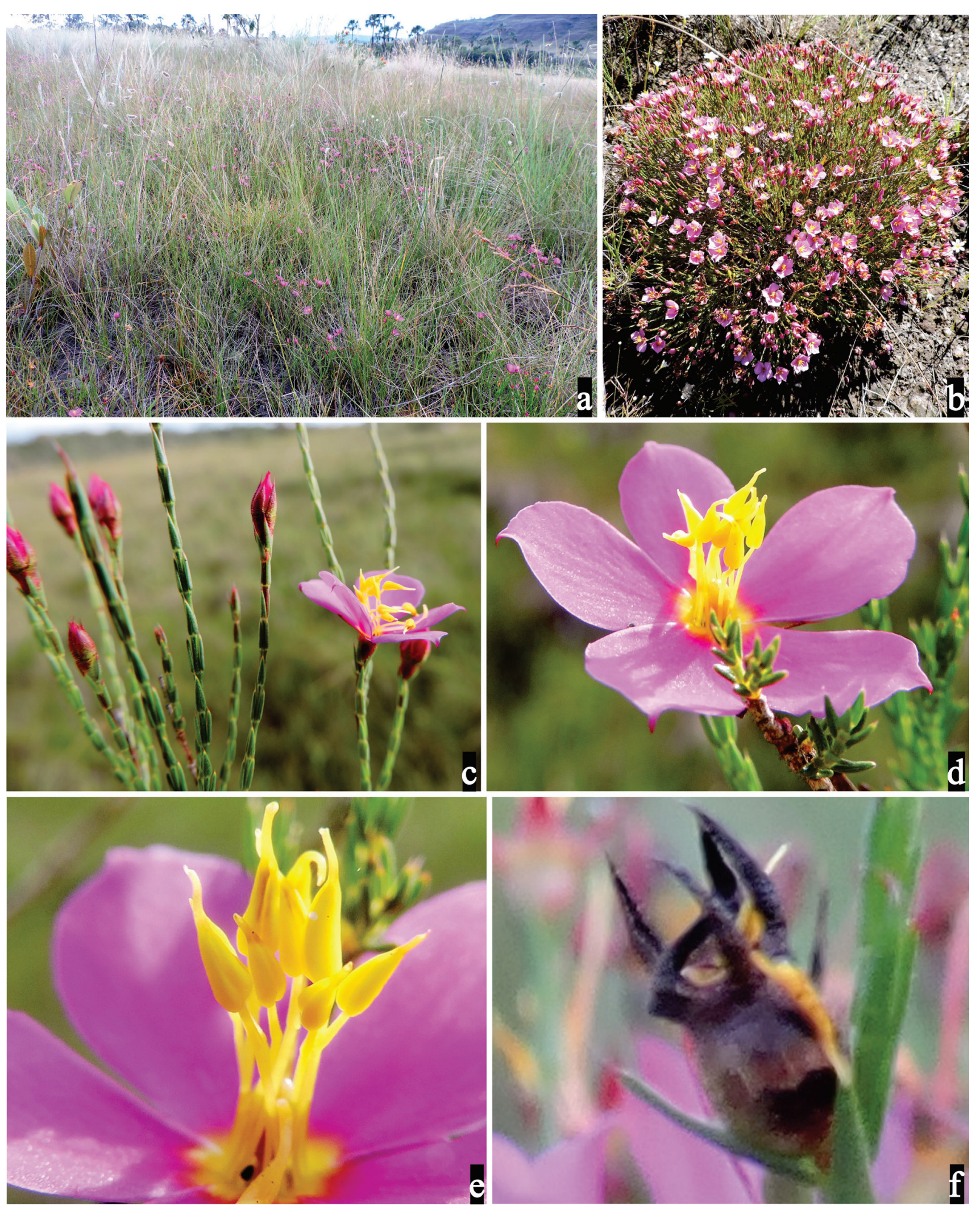

Figura 17. a-f. Microlicia psammophila Wurdack. a. Habitat. b. Hábito. c. Ramo fértil. d. Flor. e. Androceu. f. Cápsula.

Figure 17. a-f. Microlicia psammophila Wurdack. a. Habitat. b. Habit. c. Fertile branch. d. Flower. e. Androecium. f. Mature fruit with hypanthium. 
julho e com apenas fruto em novembro. É facilmente reconhecida pelo caule cespitoso e pequeno (10$70 \mathrm{~cm}$ alt.), anteras ovoides, longamente rostradas (rostro 1-1,7 mm compr.) e com prolongamento dos estames antessépalos curtos (0,7-1,3 mm compr). Assemelha-se com Microlicia chrysoglandulosa como discutido nos comentários desta última.

12. Microlicia ramosa Pilg., Bot. Jahrb. Syst. 33(2, Beibl. 72): 18. 1903.

Figuras 16 1-z, 18 a-e

Subarbustos 0,15-2,3 m alt., eretos, cespitosos ou não. Ramos dicotômicos e tricotômicos, não corimbiformes, quando adultos cilíndricos, descorticantes e glabrescentes, quando jovens quadrangulares, híspidos e estrigoso-glandulares entremeados por glândulas punctiformes. Folhas sésseis, não imbricadas; lâminas 3,5-11 × 2-9 mm, cordadas, cartáceas, base subcordada, margem inteira, ciliada, glandular ou não, ápice agudo e apiculado, não pungente, 3-(5)-nérvias, sendo as nervuras secundárias basais, curtamente estrigosas e com glândulas punctiformes em ambas as faces. Flores 10-14 mm compr., solitárias, em ramos curtos terminais, 5-meras, pedicelo 0,4-1,5 mm compr.; hipanto $3-5,2 \times 3-5,1 \mathrm{~mm}$, infundibuliforme, pubescente, tomentoso ou hirsuto-glandular entremeado por glândulas punctiformes externamente; lacínias do cálice 1,3-3,2 × 1,2-2,2 mm, triangulares, inteiras, agudas e apiculadas, semelhantes ao hipanto, mas com glândulas em ambas as faces; pétalas 6,5-10,5 × 4,8-8 mm, púrpuras e rosa claro ou alvas, obovais, às vezes com glândulas esparsas na margem, não ciliadas, ápice discretamente oblíquo com ou sem tricoma glandular; estames 10, dimórficos, os antessépalos com filetes 2,5-5 mm compr., conectivos com 2,8-4,5 mm de prolongamento, róseos a amarelados, apêndices 1-2 mm compr., achatados, anteras 1,5-2,5 × 0,7-1,3 mm, vermelhas, róseas a amareladas, rostro $0,4-0,8 \mathrm{~mm}$ compr.; os antepétalos com filetes 2,8-5 mm compr., conectivos com $0,4-1,2 \mathrm{~mm}$ de prolongamento, amarelos, apêndices $0,2-0,5 \mathrm{~mm}$ compr., anteras 1,3-2 × 0,8-1,3 mm, amarelas, rostro 0,3-1 mm compr, ambos com filetes róseos ou branco-rosados, apêndices achatados, bilobados ou inteiros e amarelos, e anteras bi e poliesporangiadas; ovário 1,8-3,2 × 1-1,6 mm, oblongoide, 4(5)-locular, estilete 4,3-6,5 mm compr, róseo ou róseo-amarelado. Cápsulas 4,5-6,3 × 3-4,5 mm, globosas, dourados a castanhos claro. Sementes 0,4-1,2 × 0,3-0,5 mm, discretamente oblongas, douradas ou marrons.
Material examinado: Alto Paraíso de Goiás: Trilha que leva ao Salto de $80 \mathrm{~m}, 1^{\circ} 09^{\prime} 54,2^{\prime \prime} \mathrm{S}, 47^{\circ} 50^{\prime} 20,9^{\prime \prime} \mathrm{W}$, 868 m, 13-III-2015, fl., D.O. Diniz et al. 93 (UFG); Morro do Japonês, $14^{\circ} 03^{\prime} 28,8^{\prime \prime} \mathrm{S}, 4^{\circ} 32^{\prime} 8,3^{\prime \prime} \mathrm{W}$, 1516 m, 14-III-2015, fl., D.O. Diniz et al. 150 (UFG); ib., $14^{\circ} 03^{\prime} 17,8^{\prime \prime} \mathrm{S}, 47^{\circ} 32^{\prime} 8,3^{\prime \prime} \mathrm{W}, 1554 \mathrm{~m}, 3-\mathrm{V}-2015$, fl., D.O. Diniz et al. 289, 290, 291, 292 (UFG), ib., $14^{\circ} 02^{\prime} 32,6^{\prime \prime S}, 47^{\circ} 31^{\prime} 37,4^{\prime \prime} \mathrm{W}, 1549$ m, 3-V-2015, fl., D.O. Diniz et al. 260, 262, 263, 264, 267, 268, 271,

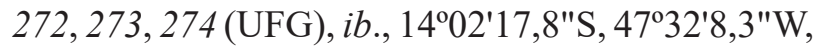
1554 m, 3-V-2015, fl., D.O. Diniz et al. 289, 290, 291, 292 (UFG), ib., 1402'31,7"S, 47³1'37,4"W, 1544 m, 3-V-2015, fl., D.O. Diniz et al. 317 (UFG),

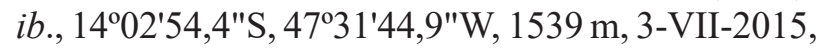
fl., fr., D.O. Diniz et al. 439 (UFG), ib., 1403'39"S, $47^{\circ} 31^{\prime} 45,2^{\prime \prime} \mathrm{W}, 1585$ m, 3-VII-2015, fl., fr., D.O. Diniz et al. 450, 452, 455, 456 (UFG); Margem esquerda da GO 118, sentido Alto Paraíso de Goiás-Teresina, 135' $51,2^{\prime \prime} \mathrm{S}, 4^{\circ} 300^{\prime} 27,8^{\prime \prime} \mathrm{W}, 1519 \mathrm{~m}, 18-\mathrm{IV}-2015$, fl., D.O. Diniz et al. 183 (UFG); ib., 1359'2,8"S, 47 $30^{\prime} 44,8^{\prime \prime} \mathrm{W}, 1467$ m, 19-IV-2015, fl., D.O. Diniz et al. 167, 168 (UFG); ib., fl., fr., D.O. Diniz et al. 169 (UFG); posto vale da lua, $13^{\circ} 58^{\prime} 51,2^{\prime \prime} \mathrm{S}, 47^{\circ} 30^{\prime} 27,8^{\prime \prime} \mathrm{W}$, 1519 m, 19-IV-2015, fl., D.O. Diniz et al. 183 (UFG); área lateral ao morro da Baleia, $14^{\circ} 07^{\prime} 19,5^{\prime \prime S}$, 47040'5,1"W, 1221 m, 20-IV-2015, fl., fr., D.O. Diniz et al. 221 (UFG); trilha que leva às cachoeiras de $80 \mathrm{~m} \mathrm{e}$ $120 \mathrm{~m}, 1^{\circ} 09^{\prime} 58,4^{\prime \prime} \mathrm{S}, 47^{\circ} 49^{\prime} 34,6^{\prime \prime} \mathrm{W}, 978 \mathrm{~m}, 2-\mathrm{V}-2015$, fl., D.O. Diniz et al. 229, 230, 231, 232 (UFG), ib., $14^{\circ} 09^{\prime} 49,9^{\prime \prime} \mathrm{S}, 47^{\circ} 49^{\prime} 55^{\prime \prime} \mathrm{W}, 930 \mathrm{~m}, 2-\mathrm{V}-2015$, fl., D.O. Diniz et al. 239 (UFG); morro Chapado, 1407'24"S, 4701'10,8"W, 1228 m, 28-IV-2016, fl, D.O. Diniz et al. 860 (UFG); à $400 \mathrm{~m}$ atrás do alojamento principal do parque, $14^{\circ} 09^{\prime} 32,3^{\prime \prime} \mathrm{S}, 47^{\circ} 47^{\prime} 34,8^{\prime \prime} \mathrm{W}$, 1078 m, 21-V-2016, fl., D.O. Diniz et al. 927 (UFG); à $7 \mathrm{Km}$ do morro do Japonês, à $20 \mathrm{Km}$ de Alto Paraíso de Goiás na GO-118 em direção a Teresina de Goiás, 135'ㄴ,8"S, 47³0'32,5"W, 1495 m, 29-VII-2016, fr., D.O. Diniz et al. 946, 951, 955 (UFG), ib., fl., D.O. Diniz et al. 953 (UFG); parada à $5 \mathrm{Km}$ de Alto Paraíso de Goiás, $1 \mathrm{Km}$ de dentro do parque, para GO-118 de Alto Paraíso de Goiás para Teresina de Goiás, $14^{\circ} 5^{\prime} 22,3^{\prime \prime} \mathrm{S}, 47^{\circ} 32^{\prime} 39,9^{\prime \prime} \mathrm{W}, 1298 \mathrm{~m}, 29-\mathrm{VII}-2016$, fr., D.O. Diniz et al. 1014, 1017 (UFG); parada à $6 \mathrm{Km}$ de Alto Paraíso de Goiás, $500 \mathrm{~m}$ de dentro do parque, 14'5'12,1"S, 47³1'28,4"W, 1366 m, 19-VIII-2016, fr., D.O. Diniz et al. 1064 (UFG); trilha para as sete quedas do rio Preto, 28-X-2016, 14 ${ }^{\circ} 06^{\prime} 48,9^{\prime \prime} \mathrm{S}$, 47044'51,1"W, 1213 m, fr., D.O. Diniz et al. 1094 (UFG). Cavalcante: ca. 150 m à esquerda da GO-118, sentido Alto Paraíso a Teresina de Goiás, $13^{\circ} 55^{\prime} 13^{\prime \prime S}$, 

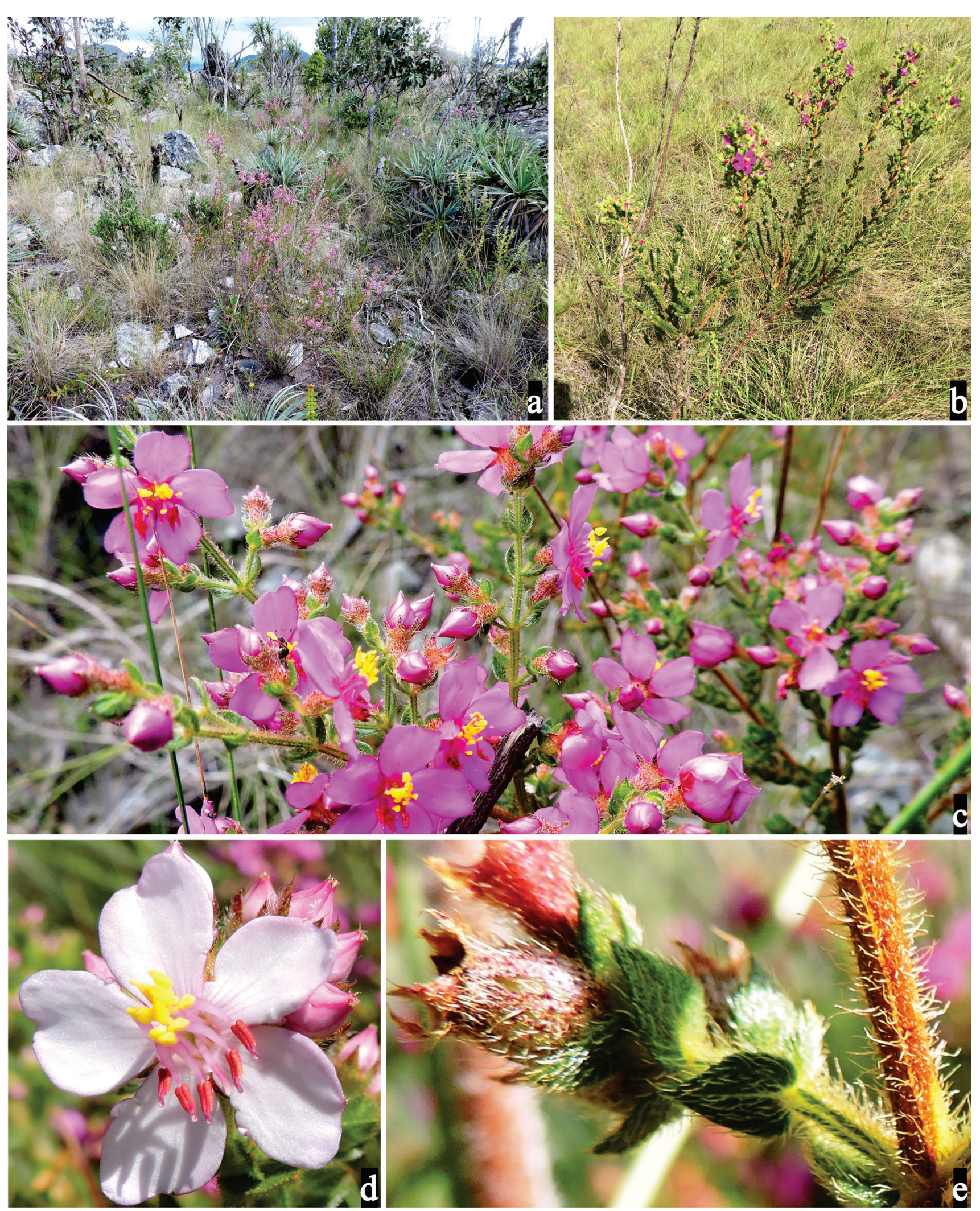

Figura 18. a-e. Microlicia ramosa Pilg. a. Habitat. b. Habit. c. Ramo fértil. d. Flor. e. Cápsula.

Figure 18. a-e. Microlicia ramosa Pilg. a. Habitat. b. Habit. c. Fertile branch. d. Flower. e. Mature fruit with hypanthium. 
47²5'23"W, 1414 m, 19-IV-2015, fl., M.J. Silva et al. 6591, 6620, 6621 (UFG).

Material examinado adicional: BRASIL. GoIÁs: Alto Paraíso de Goiás, Chapada dos Veadeiros, 8-VII-1972, fl., J.A. Rizzo et al. 8172 (UFG), ib., alto do morro ca. $6 \mathrm{Km}$ à leste de Alto Paraíso, $14^{\circ} 07^{\prime} \mathrm{S}, 47^{\circ} 30^{\prime} \mathrm{W}$, 15-II-1979, fl., F. Cardoso \& M. S. G. Ferreira 33 (UB), ib., $15 \mathrm{Km}$ de Alto Paraíso em direção a Terezina de Goiás, $13^{\circ} 46^{\prime} \mathrm{S}, 4^{\circ} 30^{\prime} \mathrm{W}, 23-\mathrm{V}-1994$, fl., fr., $C$. Munhoz et al. 149 (UB), ib., estrada de Alto Paraíso em direção a Terezina de Goiás, GO-118, 24-V-1994, fl., B.M.T. Walter 2109 (UB), Pirenópolis, Parque Estadual da Serra dos Pireneus, 19-IV-2007, fl., Faria Júnior, J.E.Q. \& Santos, M.L. 159 (HUEG).

Espécie endêmica de Goiás (Flora do Brasil 2020). Foi encontrada em cerrado típico e rupestre, campos rupestres e campos úmidos, próximo ou não de corrégos temporários entre 793-1559 metros de altitude. Floresce e frutifica de março a junho e em agosto, outubro e novembro.

Microlicia ramosa, possui caule bastante ramificado, cespitoso ou não, que juntamente com as folhas cordadas com glândulas punctiformes em ambas as faces, nas lacínias do cálice e nas pétalas e o hipanto infundibuliforme com tricomas glandulares a torna facilmente identificada. Confunde-se com $M$. ordinata conforme discutido nos comentários deta ultima.

13. Microlicia scoparia DC., Prodr. 3: 120. 1828.

Figuras 19 a-k, 20 a-d

Subarbustos 0,12-0,6 m alt., eretos, não cespitosos. Ramos dicotômicos, quando adultos cilíndricos, glabros e decorticantes, quando jovens quadrangulares com glândulas arredondadas, ambos glabros. Folhas sésseis, discretamente imbricadas; lâminas 4-9 × 0,5-1,5 mm, lanceoladas ou linearlanceoladas, cartáceas, base truncada, margem inteira, não ciliada, ápice agudo e apiculado, não pungente, 1-nérvias, glabras e com glândulas arredondadas em ambas as faces, porém mais evidentes na face abaxial. Flores 10-13,5 mm compr., solitárias, 5-meras, pedicelo 1,2-2 mm compr.; hipanto 2,3-3,4 × 1,6-2,5 $\mathrm{mm}$, estriado, estreito campanulado, glabro e com glândulas punctiformes douradas externamente; lacínias do cálice 2,5-4 × 1,4-2 mm, triangulares, inteiras com glândulas circulares na margem, ápice agudo e apiculado, semelhantes ao hipanto, com nervura calosa externamente, glabras internamente; pétalas 8-11 × 4-6 mm, brancas, elípticas, glabras, agudo ou oblíquo-mucronulado, margem não ciliada; estames 10, dimórficos, os antessépalos, com filetes 3,5-4,5 mm compr., conectivos 3,2-5 mm de prolongamento, apêndices com 0,8-1,2 mm compr., anteras $1,8-2,2 \times 0,5-0,8 \mathrm{~mm}$, amarelas, rostro 0,7-0,9 mm compr.; os antepétalos com filetes 3,5-4,5 mm compr., conectivos com 1,6-2 mm de prolongamento, apêndices com 0,2-0,3 mm compr., anteras 1-2 $\times 0,7-0,9 \mathrm{~mm}$, amarelas, rostro $0,5-0,8 \mathrm{~mm}$ compr, ambos com filetes, conectivos e apêndices amarelos, estes últimos achatados e inteiros e com anteras poliesporangiadas e amarelas. Ovário 1,3-2,2 × 1,0-1,7 mm, oblongoide, 4-locular, estilete 5-8,5 mm compr., amarelo. Cápsulas 4-7 × 2,5-3,7 mm, tubulosas, caramelas. Sementes 0,4-0,8 $\times 0,2-0,3 \mathrm{~mm}$, oblongas, douradas.

Material examinado: Alto Paraíso de Goiás: após rio Preto em direção ao morro Peito de Moça, $14^{\circ} 03^{\prime} 34,3^{\prime \prime} \mathrm{S}, 47^{\circ} 38^{\prime} 24,5^{\prime \prime} \mathrm{W}, 1181 \mathrm{~m}, 19-\mathrm{VIII}-2015$, fr., D.O. Diniz et al. 545 (UFG); proximidades do Morro do Japonês, 25-VI-2016, fl., fr. M.J. Silva et al. 7490, 7491, 7492, 7493 (UFG).

Material examinado adicional: BRASIL. Goiás: Chapada dos Veadeiros, Alto Paraíso de Goiás, à $8 \mathrm{Km}$ de Alto Paraíso, 30-V-1994, fl., S. Bridgewater et al. S226(UFG), ib., 24-VI-1994, fl., Gomes-Klein et al. 2455 (UFG).

Espécies até então considerada endêmica de Minas Gerais (Flora do Brasil 2020) e, portanto, reportada primeiramente para o Estado de Goiás. Foi coletada em cerrado rupestre próximo ou em córregos, crescendo sobre fendas de rochas ou barrancos com flores no mês de junho e com frutos em agosto.

Pode ser reconhecida pelo hábito, folhas e ramos delicados, porte diminuto (até $60 \mathrm{~cm}$ alt.), flores com pétalas brancas, anteras amarelas e hipanto verde-rosado e estriado e folhas lanceoladas e linearlanceoladas com glândulas arredondadas. Relaciona-se morfologicamente com Microlicia chrysoglandulosa conforme apresentado nos comentários desta última.

\section{Microlicia serpyliifolia D.Don, Mem. Wern. Nat.}

Hist. Soc. iv. 302. 1823.

Figura 191 1-x

Subarbustos ca. $45 \mathrm{~cm}$ alt, eretos, não cespitosos. Ramos dicotômicos, não corimbiformes, quando adultos, subcilíndricos, decorticantes, glabros ou glabrecentes, quando jovens quadrangulares, glabros e com glândulas arredondadas. Folhas sésseis ou 


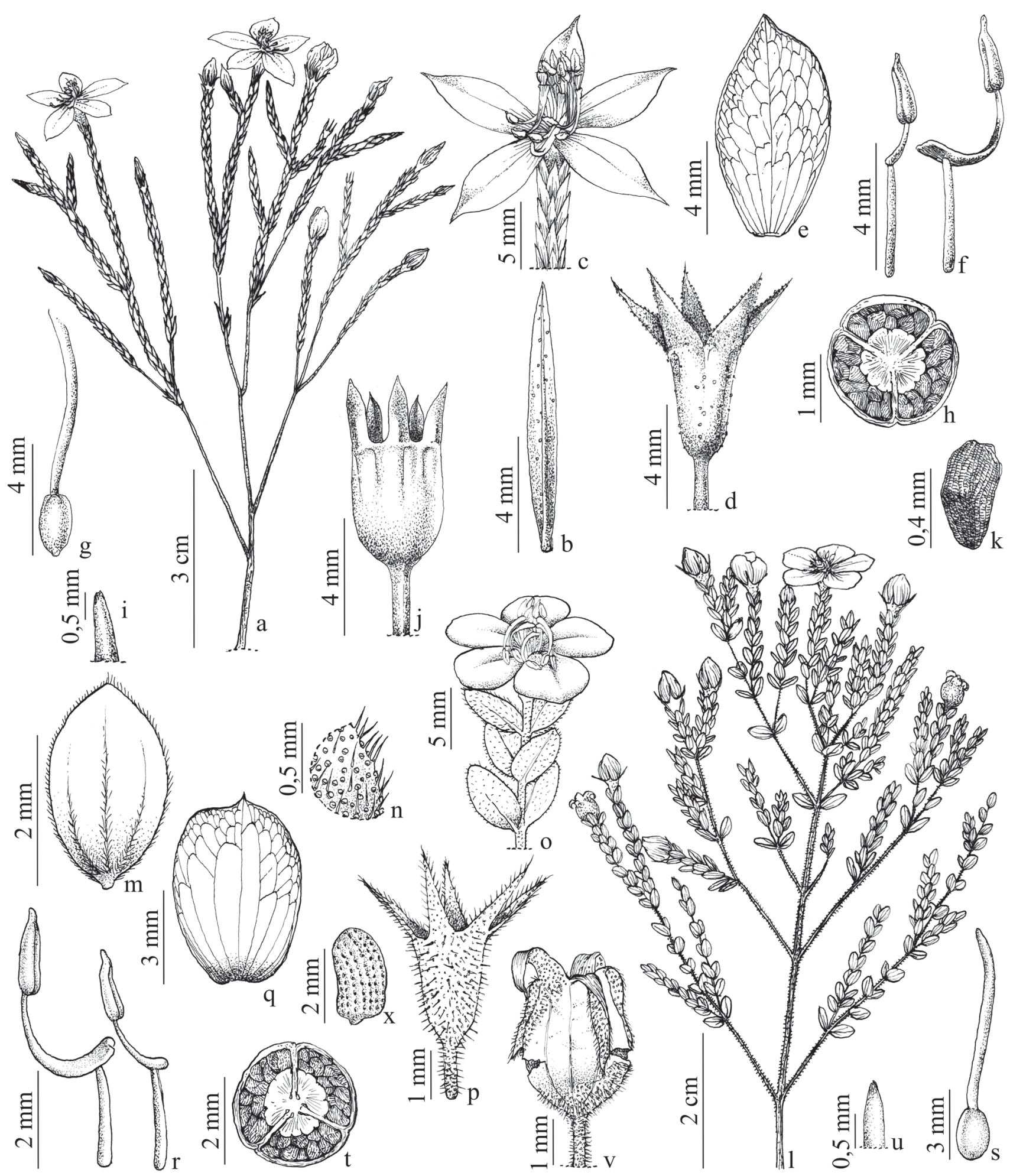

Figura 19. a-k. Microlicia scoparia DC. a. Hábito. b. Folha. c. Flor. d. Cálice. e. Pétala. f. Estames, antessépalo (direita), antepétalo (esquerda). g. Gineceu. h. Corte transversal do ovário. i. Detalhe do ápice do estilete. j. Cápsula. k. Semente. 1-x. M. serpyliifolia D.Don. 1. Hábito. m. Folha. n. Detalhe do indumento da folha. o. Flor. p. Cálice. q. Pétala. r. Estames, antessépalo (direita), antepétalo (esquerda). s. Gineceu. t. Corte transversal do ovário. u. Detalhe do ápice do estilete. v. Cápsula. x. Semente.

Figure 19. a-k. Microlicia scoparia DC. a. Habit. b. Leaf. c. Flower. d. Hypanthium and sepals. e. Petal. f. Larger stamen (right), smaller stamen (left). g. Gynoecium. h. Cross section of ovary. i. Apex of stigma. j. Mature fruit with hypanthium. k. Seed. 1-x. M. serpyliifolia D.Don. 1. Habit. m. Leaf. n. Leaf indument detail. o. Flower. p. Hypanthium and sepals. q. Petal. r. Larger stamen (right), Smaller stamen (left). s. Gynoecium. t. Cross section of ovary. u. Apex of stigma. v. Mature fruit with hypanthium. x. Seed. 


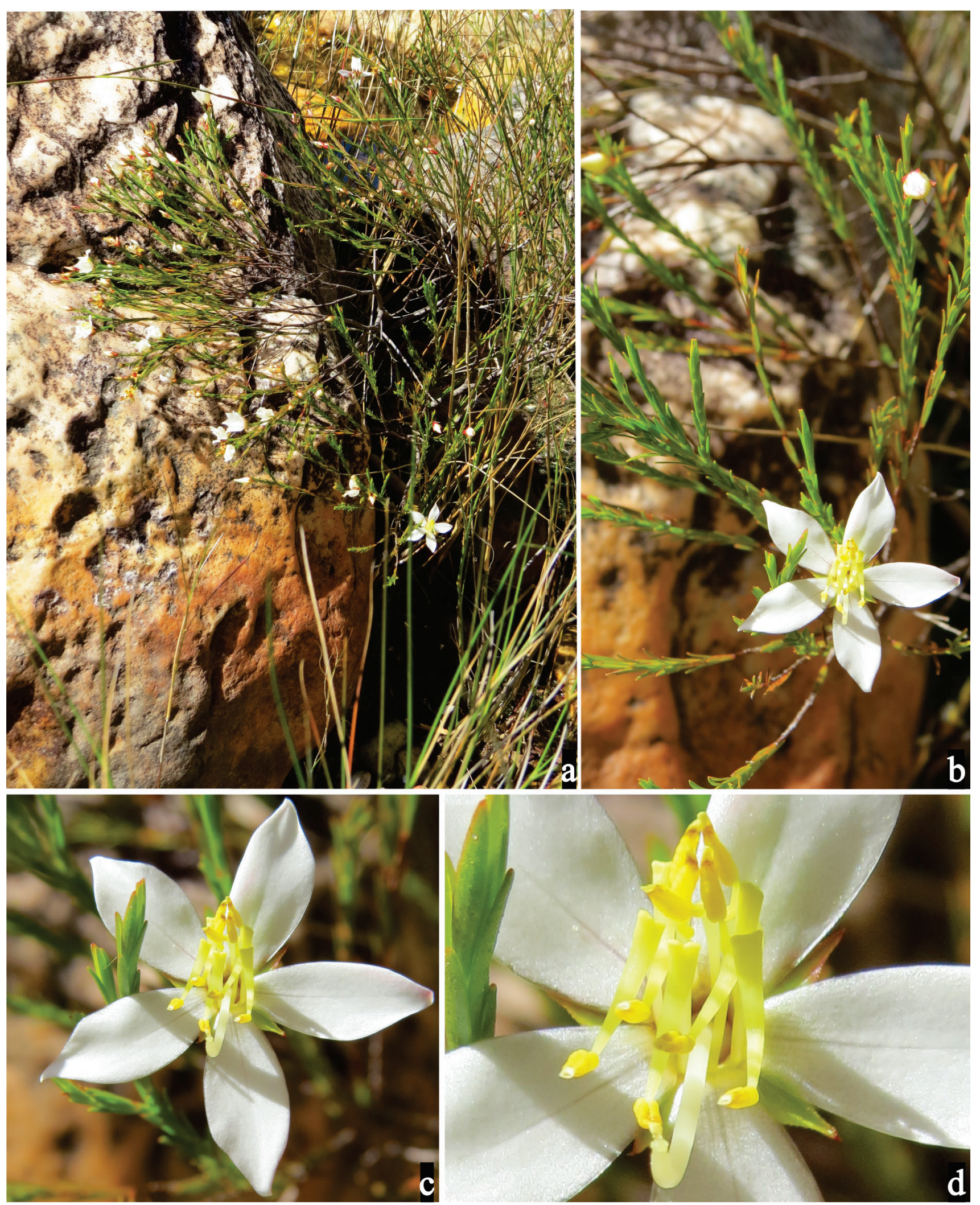

Figura 20. a-d. Microlicia scoparia DC. a. Hábito. b. Ramo fértil. c. Flor. d. Androceu e gineceu.

Figure 20. a-d. Microlicia scoparia DC. a. Habit. b. Fertile branch. c. Flower. d. Androecium and gynoecium. 
com pecíolo 0,2-0,5 mm compr., não imbricadas; lâminas 3,5-7 × 1,6-4,2 mm, elípticas, cartáceas, base obtusa, margem serreado-ciliada, ápice mucronulado, não pungente, 3-nérvias, estrigosas e com glândulas em ambas as faces. Flores 12-13,3 mm compr., solitárias, 5-meras, pedicelo 2,7-3,8 mm compr.; hipanto 3,5-4 × 2,7-3 mm, campanulado, não costado, curtamente estrigoso e com glândulas punctiformes externamente; lacínias do cálice 2,5-2,8 × 1,1-1,3 mm, triangulares, ciliadas, agudas e apiculadas, semelhantes ao hipanto; pétalas 7,5-8,2 × 4,9-5,3 $\mathrm{mm}$, róseas, obovais, com glândulas esparsas no terço superior, margem não ciliada, ápice obtuso e mucronulado; estames 10, subisomórficos, os antessépalos com filetes 3-3,2 mm compr., conectivos com 3,6-3,9 mm de prolongamento, apêndices 1-1,2 mm compr., anteras 1,8-2,2 × 0,7-1 mm, róseas, rostro 0,3-0,4 mm compr.; os antepétalos com filetes 2,8-3 mm compr., conectivos 1,5-1,6 $\mathrm{mm}$ de prolongamento, apêndices 0,2-0,3 mm compr., anteras 1,6-1,8 × 0,7-0,8 mm, amarelas, rostro 0,2-0,3 mm compr., ambos com filetes róseo-amarelados, conectivos amarelos, apêndices achatados e amarelos e anteras bitetraesporangiadas; ovário 2,5-2,8 × 1,5-2 mm, oblongoide, 3-locular, estilete 7,8-8,2 mm compr., róseo. Cápsulas 4-5,2 × 2,5-3,2 mm, ovoides, marrons. Sementes 0,4-0,5 × 0,2-0,3 mm, oblongas, douradas.

Material examinado: Alto Paraíso de Goiás: Morro do Japonês, $14^{\circ} 02^{\prime} 54,4^{\prime \prime} \mathrm{S}, 4^{\circ} 31^{\prime} 44,9^{\prime \prime} \mathrm{W}, 1539$ m, 03.VII.2015, fl., fr. D.O. Diniz et al. 433 (UFG).

Material examinado adicional: BRASIL. DisTRITO FEDERAL: Fazenda Água limpa, campo experimental da UNB, $15^{\circ} 57^{\prime} \mathrm{S}, 47^{\circ} 54^{\prime} \mathrm{W}$, sd, fr., J.N. Peters \& F. Cardoso Silva 6506 (HUEG). Goiás: Cristalina, $16^{\circ} 45^{\prime} \mathrm{S}, 47^{\circ} 40^{\prime} \mathrm{W}, 6-\mathrm{I}-1996$, fl., G.L. Moretto \& $C$. Proença 30 (UB). Pirenópolis, Serra dos Pireneus, área próximo a estrada do portal do parque, à direita em direção a Cocalzinho em campo sujo úmido, $15^{\circ} 48^{\prime} 33,5^{\prime \prime S}, 48^{\circ} 51^{\prime} 51^{\prime \prime W}, 1250$ m, 11-XII-2005, fr., M. Aparecida da Silva et al. 5836 (UFG, HUFU).

Espécie reportada para Bahia, Distrito Federal, Goiás e Minas Gerais (Kinoshita et al. 2007, Flora do Brasil 2020). Foi encontrada em apenas uma localidade da área estudada crescendo em campo úmido com flores e frutos no mês de julho.

Relaciona-se morfologicamente com $M$. vestita pelo hábito subarbustivo delicado, flores róseas e folhas com margem ciliada. Entretanto, M. serpyliifolia apresenta ramos jovens com glândulas (vs. ramos jovens sem glândulas em $M$. vestita), folhas elípticas (vs. lanceoladas ou oval-lanceoladas), lacínias do cálice com margem ciliada (vs. não ciliada) e anteras bi-tetraesporangiadas (vs. poliesporangiadas).

15. Microlicia stenodonoides D.O. DinizNeres \& M.J. Silva, Syst. Bot. 42(3): 554. 2017. Figuras 21 a-n, 22 a-e

Árvores anãs com $0,45 \mathrm{~m}$ alt., ou até 2,5 m, eretas. Caule com $5-10 \mathrm{~cm}$ diâmetro; ramos candelabriformes dicotômicos e não corimbiformes, quando adultos, decorticantes e com evidentes cicatrizes foliares, quando jovens cilíndricos, com glândulas arredondadas, ambos glabros. Folhas sésseis distribuídas no ápice dos ramos em um aspecto similar a uma roseta; lâminas 2-4,5 × 0,5-1,8 cm, oblongoelípticas, oblongo-obovadas ou menos frequentemente espatulado-obovais, coriáceas, base truncada, margem inteira, não ciliada, ápice obtuso, não pungente, 3-5-nérvias, glabras e com glândulas arredondadas em ambas as faces. Flores 2,5-4 cm compr., solitárias, 4, 5 ou 6-meras, sésseis; hipanto 7-8 $\times 5-6 \mathrm{~mm}$, campanulado, glabro e com glândulas arredondadas externamente; lacínias do cálice 6,5-7,6 × 1,5-2,7 mm, triangulares, inteiras, com nervura central destacada externamente, semelhantes ao hipanto, ápice agudo, mucronulado; pétalas 2-3,6 × 1,2-1,9 cm, rosa pink com base amarela, obovais ou oblongo-obovais, glabras, ápice assimétrico-obtuso, margem inteira, não ciliada; estames 8, 10 ou 12, dimórficos, os antessépalos com filetes 6-6,9 mm compr., conectivos com 6,5-8 $\mathrm{mm}$ de prolongamento, apêndices 1,1-1,9 mm compr., achatados, anteras 3,1-4,7 × 0,8-1,3 mm, amarelas, rostro 0,3-1 $\mathrm{mm}$ compr.; os antepétalos com filetes 5,5-6,5 mm compr., conectivos 1,2-2 mm de prolongamento, apêndices 0,4-0,7 mm compr., anteras 3,5-4,1 $\times$ 0,8-1,2 $\mathrm{mm}$, amarelas, rostro 0,3-0,8 mm compr., ambos com filetes, conectivos e apêndices amarelos, estes últimos achatados e bilobados, todos com anteras poliesporangiadas e amarelas; ovário 4-4,8 × 2,7-3,2 mm, oblongoide, 4-locular, estilete 1,9-2,2 cm compr., róseo. Cápsulas 5-10 $\times 4,8-5,2 \mathrm{~mm}$, globosas, marrons, douradas ou avermelhadas. Sementes 1-1,5 × 1-1,4 mm, trapezoidais ou prismáticas, marrons.

Material examinado: Alto Paraíso de Goiás, Região do Mulungu, $14^{\circ} 06^{\prime} 52^{\prime \prime S}, 47^{\circ} 38^{\prime} 46^{\prime \prime} \mathrm{W}, 1246 \mathrm{~m}$, 24-IV-2013, fr., R.F. Vieira et al. 2561 (parátipo) (CEN); ib., 14 $06^{\prime} 52^{\prime \prime S}, 4^{\circ} 38^{\prime} 41^{\prime \prime} \mathrm{W}, 1258 \mathrm{~m}$, 20-XI-2013, fr. R.B.N. Alves et al. 83 (parátipo) 


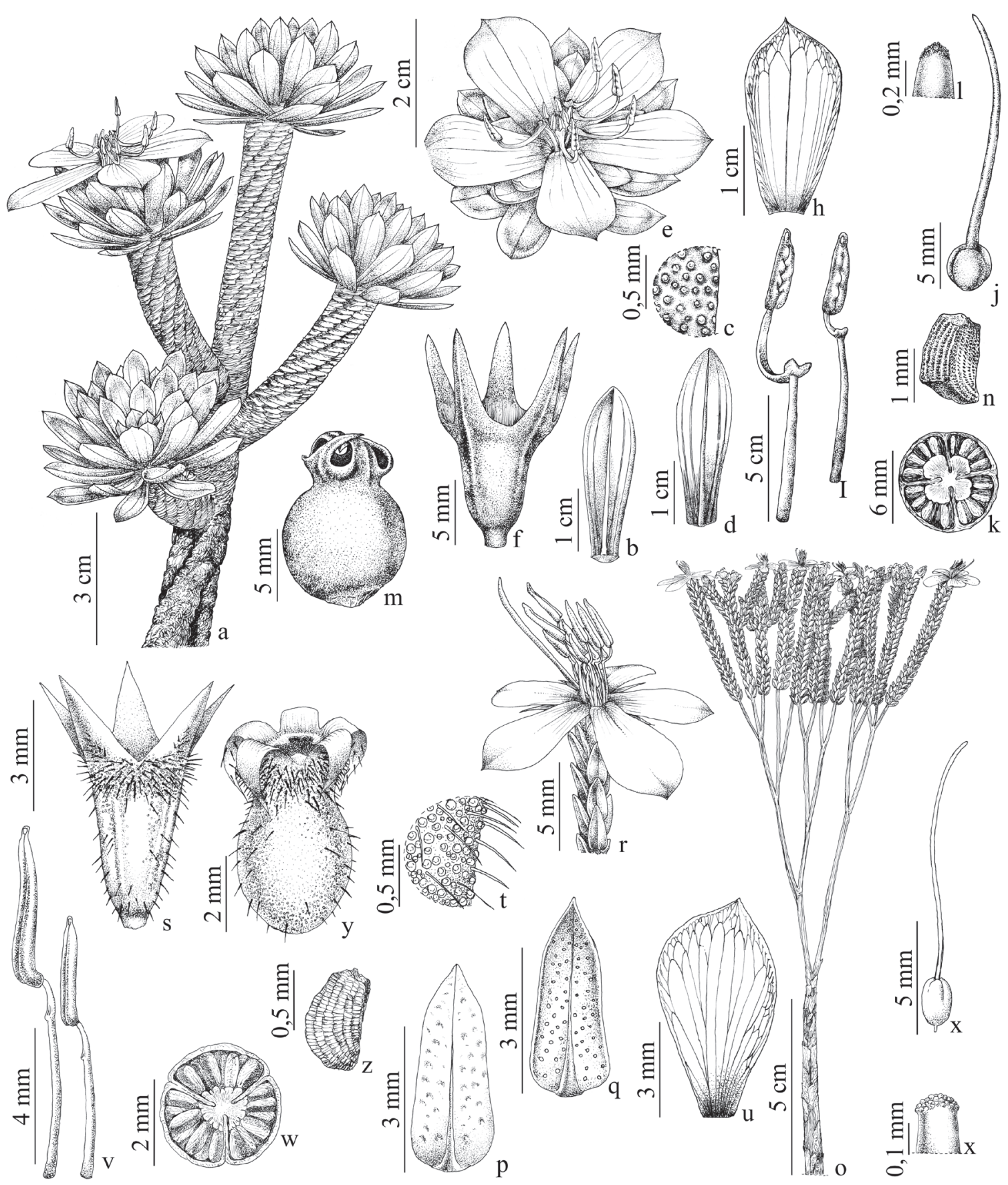

Figura 21. a-n. Microlicia stenodonoides D.O. Diniz-Neres \& M.J. Silva. a. Hábito. b. Folha (face adaxial). c. Detalhe das glândulas da folha. d. Folha (Face abaxial). e. Flor. f. Cálice. g. Lacínia do cálice. h. Pétala. i. Estames, antessépalo (esquerda), antepétalo (direita). j. Gineceu. k. Corte transversal do ovário. 1. Detalhe do ápice do estilete. m. Cápsula. n. Semente. o-z. M. veadeirana D.O. Diniz-Neres \& M.J. Silva. o. Hábito. p. Folha (face adaxial). q. Folha (Face abaxial). r. Flor. s. Cálice e detalhe do indumento do hipanto. t. Pétala. u. Estames, antessépalo (esquerda), antepétalo (direita). v. Gineceu. x. Corte transversal do ovário. w. Detalhe do ápice do estilete. y. Cápsula. z. Semente, lado lateral.

Figure 21. a-n. Microlicia stenodonoides D.O. Diniz-Neres \& M.J. Silva. a. Habit. b. Leaf, adaxial surface. c. Detail of the adaxial surface of the leaf showing circular glands. d. Leaf, abaxial surface. e. Flower. f. Hypanthium and sepals. g. Detail of calyx lobes. h. Petal. i. Larger stamen (left), Smaller stamen (right). j. Gynoecium. k. Cross section of 4-locular ovary. 1. Apex of stigma. m. Mature fruit with hypanthium. n. Seed. o-z. M. veadeirana D.O. Diniz-Neres \& M.J. Silva: o. Habit. p. Leaf adaxial surface. q. leaf abaxial surface showing circular glands and revolute margin. r. Flower. s. Hypanthium and sepals, Detail of surface of hypanthium showing circular glands and tector trichomes. t. Petal. u. Larger stamen (left), Small stamen (right). v. Gynoecium. x. Section transversal of the ovary, note three locule. w. Stigmatic surface. y. mature fruit with lobes of the calyx curved. z. Seed, lateral side. 


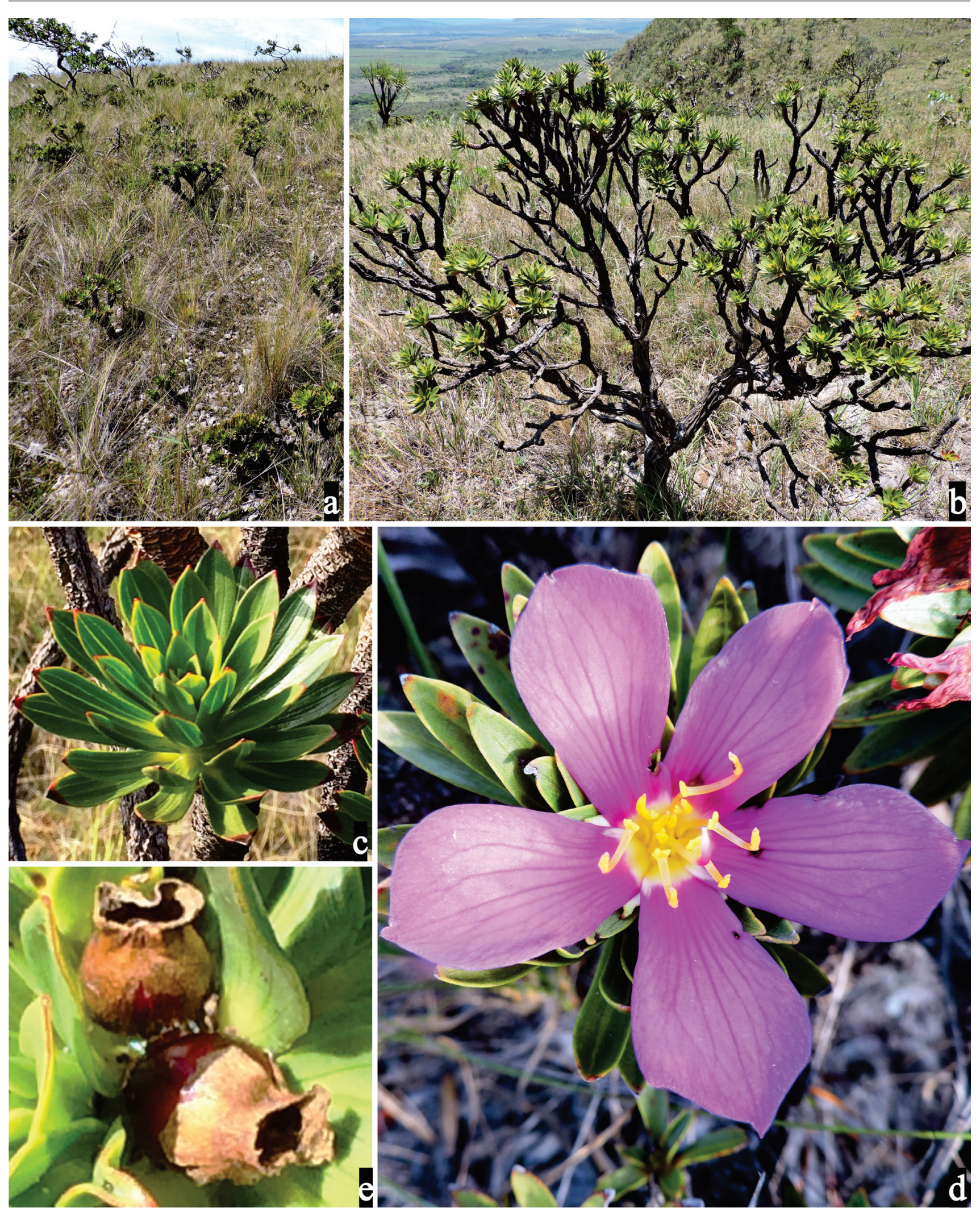

Figura 22. a-e. Microlicia stenodonoides D.O. Diniz-Neres \& M.J. Silva. a. Habitat. b. Hábito, árvore com ramos candelabriformis. c. Ramo folhoso. d. Flor. e. Cápsulas.

Figure 22. a-e. Microlicia stenodonoides D.O. Diniz-Neres \& M.J. Silva. a. Habitat. b. Habit, tree with branches candelabriformis. c. Leafy branch. d. Flower. e. Mature fruit with hypanthium. 
(CEN). Área direita do Morro da Baleia, $14^{\circ} 06^{\prime} 52,2^{\prime \prime S}$,

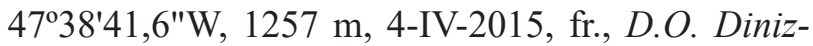
Neres et al. 418, 419, 420 (parátipos) (UFG); ib., $14^{\circ} 06^{\prime} 55^{\prime \prime S}, 47^{\circ} 38^{\prime} 38^{\prime \prime} \mathrm{W}, 1240 \mathrm{~m}, 6-\mathrm{VI}-2015$, fr., M.J. Silva et al. 6791, 6792, 6793 (parátipos) (UFG); ib., $14^{\circ} 06^{\prime} 53,5^{\prime \prime} \mathrm{S}, 47^{\circ} 38^{\prime} 46,7^{\prime \prime} \mathrm{W}, 1272 \mathrm{~m}, 20-\mathrm{VII}-2015$, fr., D.O. Diniz-Neres et al. 509, 510 (parátipos) (UFG), ib., 21-IX-2015, fr., D.O. Diniz-Neres et al. 705, 706, 707, 708 (parátipos) (UFG), ib., 11-XII-2015, fr., D.O. Diniz-Neres et al. 715, 716, 717, 720, 721, 725 (parátipos) (UFG), ib., 4-II-2016, fl., fr., D.O. Diniz-Neres et al. 795 (holótipo), 796, 798 (parátipos) (UFG), ib., fl., D.O. Diniz-Neres \& R.N. Ribeiro 797 (parátipo) (UFG); ib., 29-V.2016, fl., fr., D.O. DinizNeres \& R.N. Ribeiro 865, 866, 867, 868, 869, 870 (parátipos) (UFG).

Microlicia stenodonoides é uma das quatro espécies novas descobertas durante o desenvolvimento do projeto de mestrado da primeira autora, e encontra-se publicada (Diniz-Neres \& Silva 2017). Ela parece endêmica da área estudada e cresce em campos rupestre e úmidos em encostas ou topos de morros, formando populações agregadas entre 1240-1258 metros de altitude com flores e frutos em fevereiro e maio e com frutos em abril, junho, julho e novembro. É a única espécie do gênero com hábito arbóreo anão, caule com 5-10 cm de diâmetro na base, folhas dispostas em um aspecto de roseta na terminação de ramos e flores grandes (2,5-4 cm largura), o que a torna facilmente reconhecida distinta das demais espécies congêneres.

16. Microlicia veadeirana D.O. Diniz-Neres \& M.J. Silva, Brittonia 70(1): 84. 2018.

Figuras $21 \mathrm{o}-\mathrm{z}, 23 \mathrm{a}-\mathrm{f}$

Subarbustos 35-60 cm alt., eretos, não cespitosos. Ramos dicotômicos ou tricotômicos, corimbiformes ou não, quando adultos cilíndricos, glabros e descorticantes, quando jovens quadrangulares e pubescentes. Folhas sésseis ou com pecíolo 0,3-0,5 mm compr., laxamente imbricadas; lâminas 4,5-6,7 × 1-2,7 mm, oval-lanceoladas ou lanceoladas, cartáceas, base obtusa ou arredondada, margem inteira, levemente revoluta, não ciliada, ápice agudo e apiculado ou não, não pungente, 1-nérvias, com glândulas arredondadas em ambas as faces, porém mais evidentes na face abaxial. Dicásios e, ou flores solitárias, ambos terminais. Flores 11-15 mm compr., 5-meras, pedicelo 0,4-1,5 mm compr.; hipanto 4,8-6 × 2,3-5 $\mathrm{mm}$, campanulado, não costado com glândulas arredondadas e tricomas pubescentes externamente, os tricomas em um aspecto de coroa próximo ao ápice; lacínias do cálice 2,7-4,2 × 1,3-2,2 mm, triangulares, inteiras e ciliadas, agudas, semelhantes ao hipanto; pétalas 7,5-10 × 4-6 mm, rosas, obovais, margens não ciliadas, oblíquo, mucronuladas; estames 10, subisomórficos, os antessépalos com filetes 4-5 mm compr., conectivos com 1,7-2,5 $\mathrm{mm}$ de prolongamento, apêndices 0,2-0,6 mm compr., anteras 3,7-4,8 $\times 0,6-0,9 \mathrm{~mm}$, amarelas, rostro 0,2-0,5 mm compr.; os antepétalos com filetes 3,5-4,2 mm compr., conectivos 0,9-1,4 mm de prolongamento, apêndices $0,2-0,3 \mathrm{~mm}$ compr., anteras 2,5-3,2 $\times 0,4-0,7 \mathrm{~mm}$, amarelas, rostro 0,2-0,4 mm compr, ambos com filetes róseo-amarelados, prolongamentos dos conectivos e apêndices róseos, estes últimos achatados e inteiros a discretamente bilobados, e anteras amarelas e biesporangiadas; ovário 2,3-3,2 × 1,2-2 mm, oblongoide ou elipsoide, 3-locular, estilete 9,7-13,3 mm compr., róseo. Cápsulas 4-7× 2,3-3,7 mm, urceoladas, castanhas. Sementes $0,4-0,7 \times 0,4-0,5 \mathrm{~mm}$, oblongas curvadas ventralmente, marrons ou douradas.

Material examinado: Alto Paraíso de Goiás: Parque Nacional da Chapada dos Veadeiros, após a bifurcação que leva à Cachoeira das 7 Quedas do rio Preto, $14^{\circ} 06{ }^{\prime} 50,9^{\prime \prime} \mathrm{S}, 4^{\circ} 44^{\prime} 6,8^{\prime \prime} \mathrm{W}, 1161 \mathrm{~m}, 15-\mathrm{II}-2015$, fl, D.O. Diniz-Neres et al. 10, 11 (UFG), ib., $14^{\circ} 06^{\prime} 35,2^{\prime \prime} \mathrm{S}, 47^{\circ} 44^{\prime} 17,6^{\prime \prime} \mathrm{W}, 1147 \mathrm{~m}, 15-\mathrm{II}-2015$, fl, fr, D.O. Diniz-Neres et al. 23, 24, 26, 28, 29 (parátipos), 30 (holótipo) (UFG), ib., 1406'18,6"S, 47044'11,5"W, 1135 m, 15-II-2015, fl.,fr., D.O. Diniz-Neres et al. 33, 35 (parátipos) (UFG); ib., $14^{\circ} 06^{\prime} 16,3^{\prime \prime S}, 47^{\circ} 44^{\prime} 13,5^{\prime \prime} \mathrm{W}, 1128 \mathrm{~m}, 20-\mathrm{IV}-2015$, fr., D.O. Diniz-Neres et al. 37 (parátipo) (UFG); ib., na Trilha oposta que leva à Cachoeira das 7 Quedas do rio Preto, $1^{\circ} 06^{\prime} 8,1^{\prime \prime S}, 47^{\circ} 44^{\prime} 21,6^{\prime \prime} \mathrm{W}, 1107$ m, 15-II-2015, fl., D.O. Diniz-Neres et al. 41, 42 (parátipos) (UFG); $i b$., após rio Preto em direção ao morro Peito de Moça, $14^{\circ} 03^{\prime} 34,3^{\prime \prime S}, 4^{\circ} 38^{\prime} 24,5^{\prime \prime} \mathrm{W}, 1181 \mathrm{~m}, 19-\mathrm{IX}-2015$, fr., D.O. Diniz-Neres et al. 544 (parátipo) (UFG); próximo a trilha que leva a cachoeira das 7 quedas, imediações do rio Preto, $14^{\circ} 05^{\prime} 46,4^{\prime \prime} \mathrm{S}, 47^{\circ} 45^{\prime} 03^{\prime \prime} \mathrm{W}$, 1060 m, 20-IX-2015, fr., D.O. Diniz-Neres et al. 596, 597 (parátipos) (UFG); entrada que leva a cachoeira das 7 quedas, $14^{\circ} 05^{\prime} 44,5^{\prime \prime} \mathrm{S}, 47^{\circ} 45^{\prime} 1,6^{\prime \prime} \mathrm{W}$, $1071 \mathrm{~m}, 7-\mathrm{X}-2015$, fr., D. O. Diniz-Neres et al. 635 (parátipo) (UFG); imediações do rio Preto,

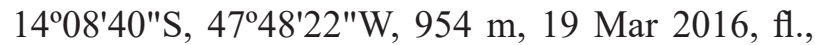
fr., M.J. Silva et al. 7446 (parátipo) (UFG); ib., 150 


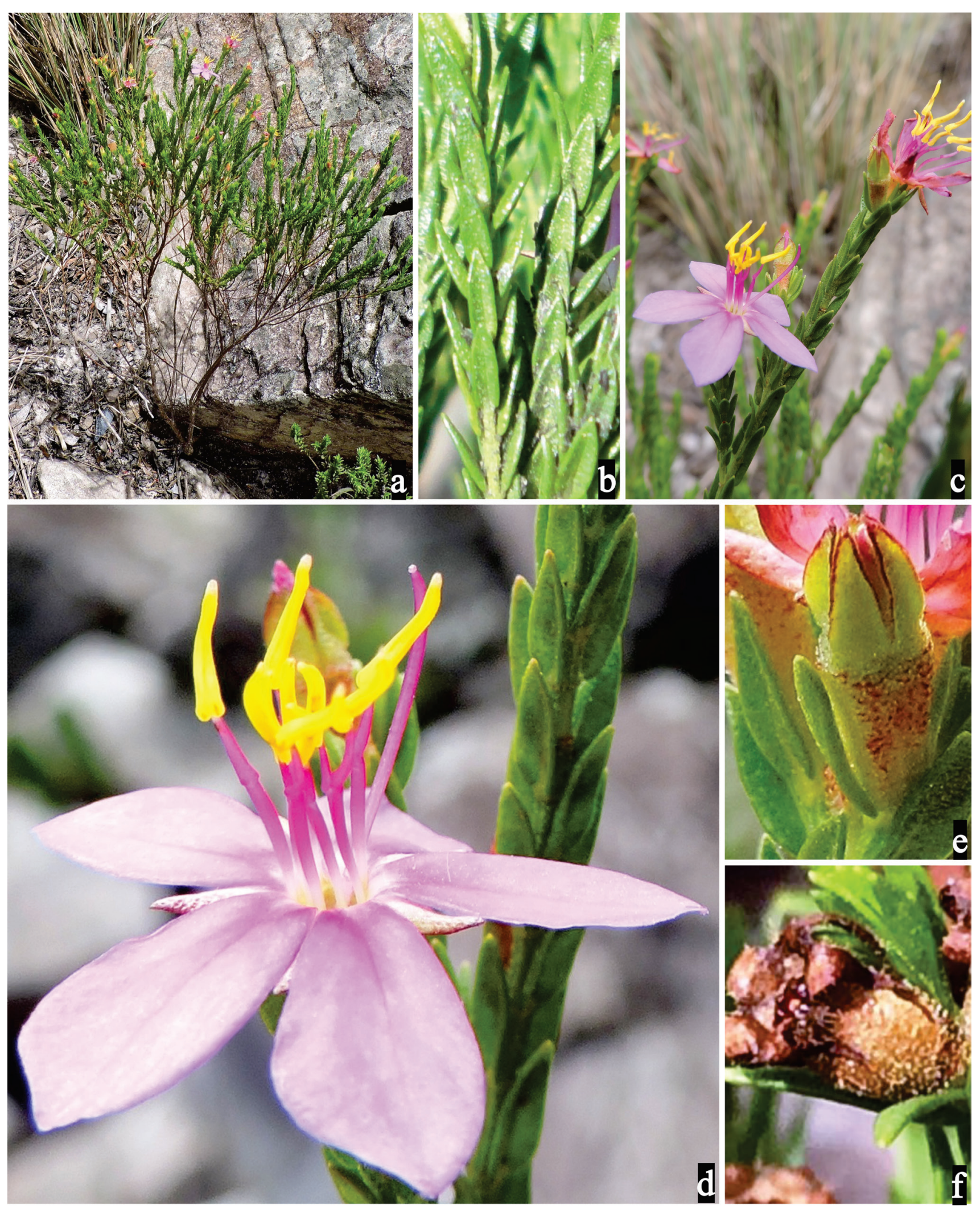

Figura 23. a-f. Microlicia veadeirana D.O. Diniz-Neres \& M.J. Silva. a. Hábito. b. Ramo folhoso. c. Ramo fértil. d. Flor. e. Hipanto. f. Cápsula.

Figure 23. a-f. Microlicia veadeirana D.O. Diniz-Neres \& M.J. Silva. a. Habit. b. Leafy branch. c. Fertile branch. d. Flower. e. Hypanthium and sepals. f. Mature fruit with hypanthium. 
metros antes do Cânion 1 às margens do rio Preto, 19-III-2016, fr., M.J. Silva et al. 7449, 7450 (parátipo) (UFG). Cavalcante: Parque Nacional da Chapada dos Veadeiros, final do parque, $14^{\circ} 04^{\prime} 21,3^{\prime \prime} \mathrm{S}, 47^{\circ} 38^{\prime} 9,3^{\prime \prime} \mathrm{W}$, 1179 m, 11-XII-2015, fl., fr., D.O. Diniz-Neres et al. 725, 726 (parátipos) (UFG).

Microlicia veadeirana, recentemente publicada (Diniz-Neres \& Silva 2018) e parece endêmica da área estudada onde forma populações isoladas em cerrado sensu stricto e campos rupestres, em geral próximo à córregos ou margem de rio, sobre solos argiloarenosos ou arenosos entre 1107-1161 m. Floresce e frutifica entre fevereiro e abril, entre setembro e outubro e no mês de dezembro.

As folhas glabras, 1-nérvias com 4,5-6,7 e numerosas glândulas, as flores róseas com anteras dos estames de ambos os ciclos amarelas, são comuns a esta espécie e a $M$. insignis, sua congênere mais morfologicamente semelhante. No entanto, Microlicia veadeirana possui estames antessépalos com prolongamento do conectivo entre 1,7-2,5 $\mathrm{mm}$ compr. e apêndices ventrais 0,2-0,6 mm compr., hipanto com glândulas e com uma coroa de tricoma apical, além de lacínias do cálice triangulares com ápice agudo, enquanto que em $M$. insignis o prolongamento dos estames do ciclo antessépalo mede 3-5 mm compr., com apêndices ventrais entre 1,2-2 mm compr., o hipanto não possui glândulas, nem coroa de tricomas e as lacínias do cálice são lanceoladas com ápice apiculado.

Microlicia veadeirana compartilha ainda do hipanto com uma coroa de tricomas no ápice com as espécies de Chaetostoma, porém, preferimos não posicioná-la neste último gênero, pela mesma possuir lâminas com glândulas, não carenadas, não pungentes e anteras biesporangiadas, caracteres estes comuns ao gênero Microlicia, diferentemente das espécies de Chaetostoma que podem ser reconhecidas pela coroa de tricomas evidentes no ápice do hipanto, folhas carenadas e pungentes sem glândulas, anteras comumente tetraesporangiadas.

17. Microlicia vestita DC., Prodr. 3: 119. 1828.

Figuras 24 a-1; 25 a-f.

Subarbustos 15-80 cm alt., eretos, não cespitosos. Ramos dicotômicos, não corimbiformes; quando adultos, glabrecentes e descorticantes, quando jovens quadrangulares, estrigosos ou seríceos. Folhas sésseis, não imbricadas; lâminas 3-8,2 × 1,3-3,5 mm, lanceoladas, elíptico-lanceoladas ou ovais, cartáceas, base obtusa, margem inteira ou serreada e ciliada, ápice mucronulado, não pungente, 3-5-nérvias, glabras ou estrigosas, os tricomas quando presentes mais abundantes na face abaxial, glândulas em ambas as faces. Flores 8-12,3 mm compr., 5-meras, solitárias, pedicelo 1-1,8 mm compr.; hipanto 2,2-4 × 2-3,2 $\mathrm{mm}$, campanulado não costado, estrigosos ou seríceos e com glândulas externamente; lacínias do cálice 1,3-3 × 0,9-1,5 mm, triangulares, inteiras, acuminadas, semelhantes ao hipanto; pétalas 6,8-8 × 3,7-5,3 mm, róseas ou brancas, obovais, glabras, margem não ciliada, apíce oblíquo-mucronulado; estames 10, dimórficos, os antessépalos com filetes 3,5-5,2 mm compr., conectivos com 3-4,3 mm de prolongamento, apêndices 1,2-2 mm compr., anteras 1,3-1,7 × 0,6-0,9 $\mathrm{mm}$, róseas, rostro $0,3-1 \mathrm{~mm}$ compr.; os antepétalos com filetes 3,8-4,6 mm compr., conectivos 0,9-1,5 $\mathrm{mm}$ de prolongamento, apêndices 0,2-0,4 mm compr., anteras 1-1,4 × 0,6-1 mm, amarelas, rostro $0,2-0,8 \mathrm{~mm}$ compr., ambos com filetes róseos, conectivos e apêndices amarelos, estes últimos achatados e inteiros e anteras poliesporangiadas; ovário 1,5-2,6 × 0,9-1,5 mm, piriforme , 3-locular, estilete 4-8 mm compr., róseo. Cápsulas 2,3-5 × 1,8$3,8 \mathrm{~mm}$, globosas, verdes, marrons ou avermelhadas. Sementes 0,6-0,8 $\times 0,3-0,5 \mathrm{~mm}$, oblongas ligeiramente curvas ventralmente, marrons.

Material examinado: Alto Paraíso de Goiás: Morro do Japonês, 1402'52,4"S, 47³1'51,1"W, 1529 m, 14-III-2015, fl., fr., D.O. Diniz et al. 124 (UFG), ib., fl., D.O. Diniz et al. 119, 120 (UFG), ib., 1403'28, "' S, 47³2'8,3"W, 1516 m, 14-III-2015, fl., fr., D.O. Diniz et al. 131, 132, 135 (UFG); ib., fl., D.O. Diniz et al. 130, 134, 136, 137, 138 (UFG); ib., 14º2'53,9"S, 47³1'49,6"W, 1534 m, 14-III-2015, fl., fr., D.O. Diniz et al. 154, 156 (UFG); ib., fl., D.O. Diniz et al. 155, 157 (UFG); ib., 14º2'54,4"S, 47³1'44,9"W, 1539 m, 3-VII-2015, fr., D.O. Diniz et al. 434, 435, 436, 437, 438 (UFG); GO-118, cerca de $3 \mathrm{Km}$ da cruz para Serra do Pouso Alto, 1359'4,9"S, 47³0'50"W, $1462 \mathrm{~m}$, 21-VIII-2015, fl., fr. D.O. Diniz et al. 506 (UFG); morro do Japonês, próximo à vereda, $14^{\circ} 03^{\prime} 33,1^{\prime \prime S}$, 47³2'12,5"W, 1505 m, 27-II-2015, fl., D.O. Diniz \& R.N. Ribeiro 826, 827 (UFG); à $5 \mathrm{Km}$ do morro do Japonês, 1359'3,9"S, 47³0'49,5"W, 1460 m, 29-VII-2016, fl., fr., D.O. Diniz et al. 968, 969, 970, 971, 972 (UFG); Cavalcante: Final do Parque, $13^{\circ} 55^{\prime} 10,3^{\prime \prime S}, 47^{\circ} 25^{\prime} 24,3^{\prime \prime} \mathrm{W}, 1396$ m, 20-XI-2015, fl., fr., D.O. Diniz et al. 669, 670, 671, 672 (UFG). 


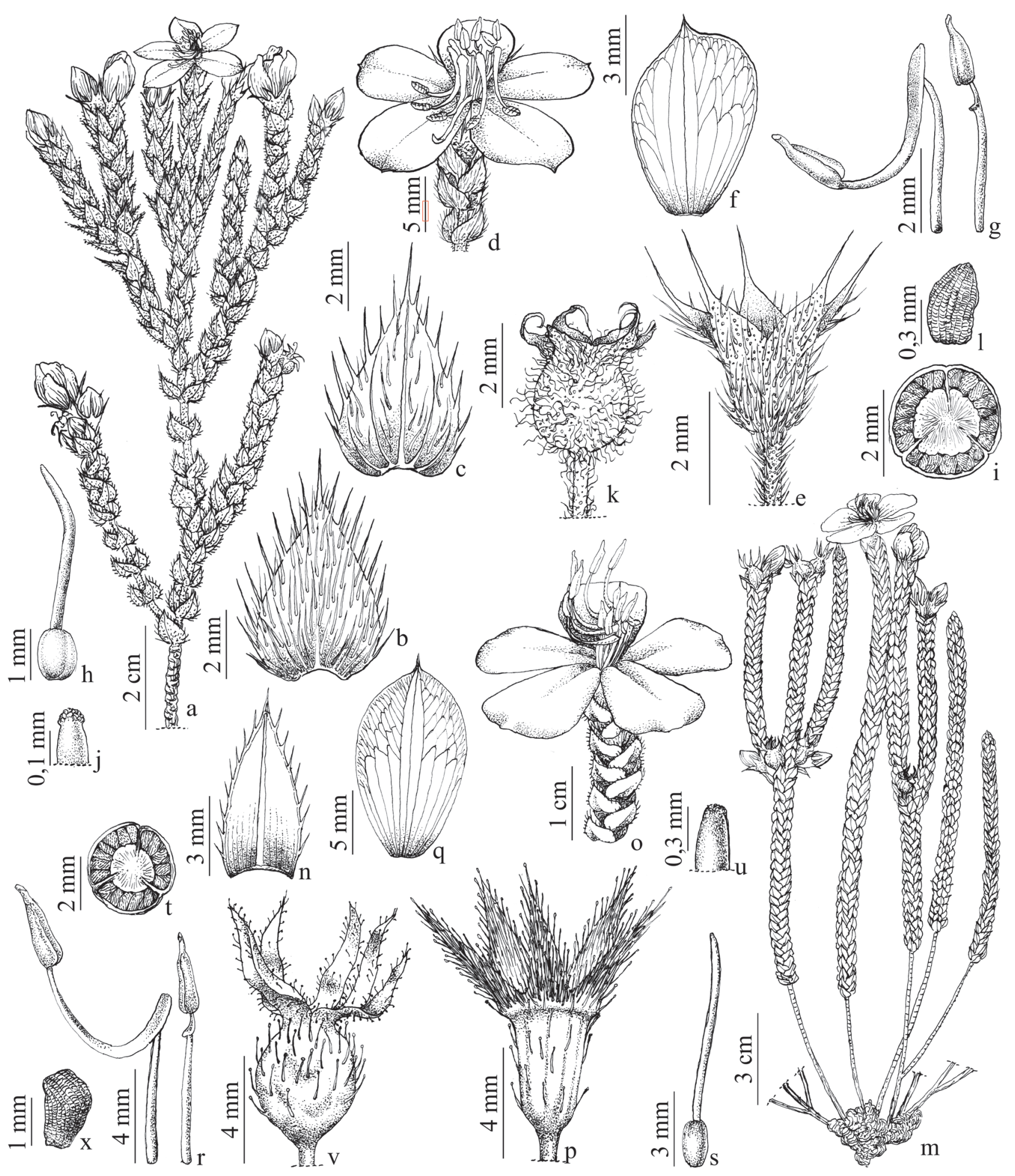

Figura 24. a-1. Microlicia vestita DC. a. Hábito. b. Folha (face adaxial). c. Folha (face abaxial). d. Flor. e. Cálice. f. Pétala. g. Estames, antessépalo (esquerda), antepétalo (direita). h. Gineceu. i. Corte transversal do ovário. j. Detalhe do ápice do estilete. k. Cápsula. 1. Semente. m-x. M. viminalis. m. Hábito. n. Folha. o. Flor. p. Cálice. q. Pétala. r. Estames, antessépalo (esquerda), antepétalo (direita). s. Gineceu. t. Corte transversal do ovário. u. Detalhe do ápice do estilete. v. Cápsula. x. Semente.

Figure 24. a-1. Microlicia vestita DC. a. Habit. b. Leaf, adaxial surface. c. Leaf, abaxial surface. d. Flower. e. Hypanthium and sepals. f. Petal. g. Larger stamen (left), smaller stamen (right). h. Gynoecium. i. Cross section of ovary. j.Apex of stigma. k. Mature fruit with hypanthium. 1. Seed. m-x. M. viminalis. m. Habit. n. Leaf. o. Flower. p. Hypanthium and sepals. q. Petal. r. Larger stamen (left), smaller stamen (right). s. Gynoecium. t. Cross section os ovary. u. Apex of stigma. v. Mature Fruit with hypanthium. x. Seed. 


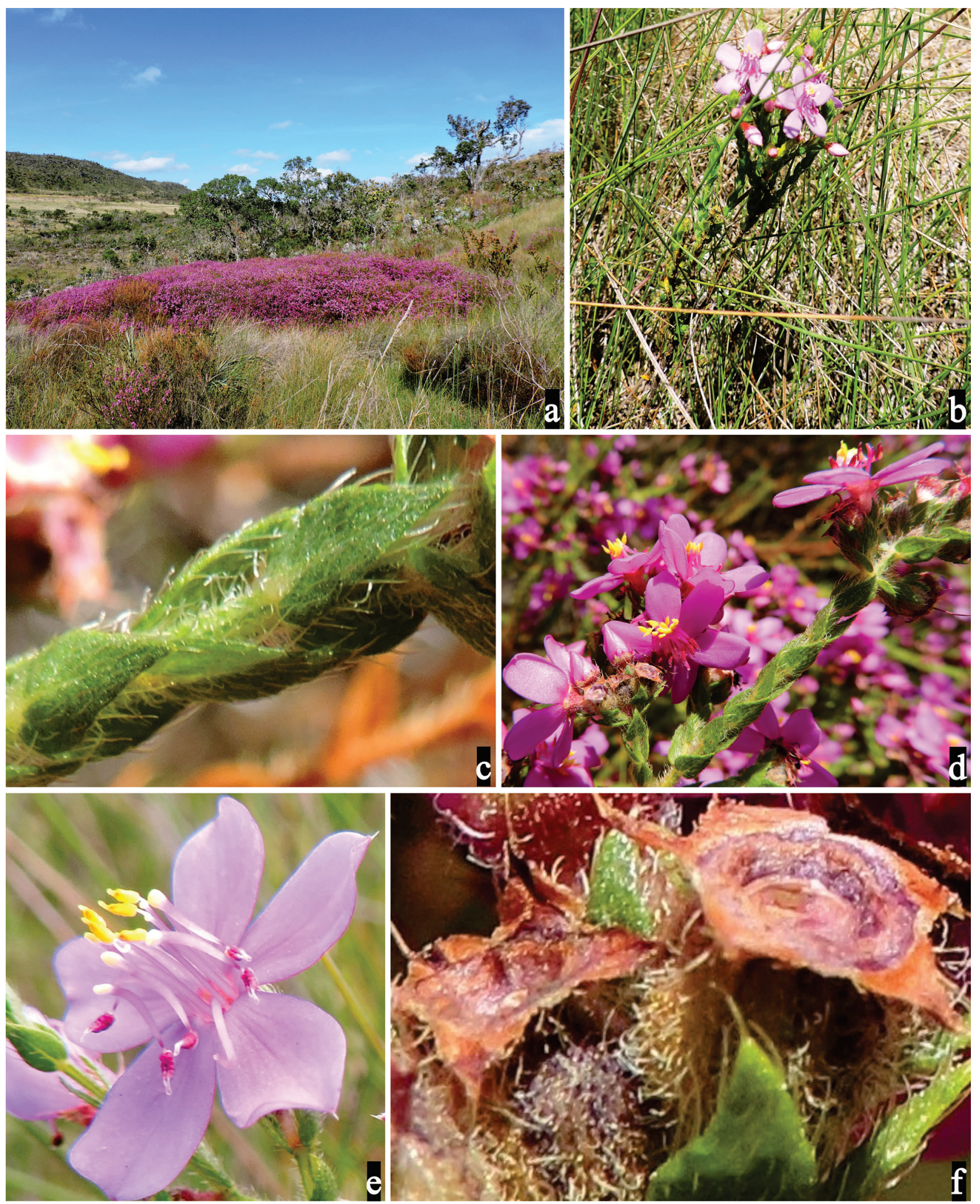

Figura 25. a-f. Microlicia vestita DC. a. Habitat. b. Hábito. c. Ramo folhoso. d. Ramo fértil. e. Flor. f. Cápsulas.

Figure 25. a-f. Microlicia vestita DC. a. Habitat. b. Habit. c. Leafy branch. d. Fertile branch. e. Flower. f. Mature Fruit with hypanthium. 
Material examinado adicional: BRASIL. GoIÁs: Alto Paraíso de Goiás: Chapada dos Veadeiros, ca. $6 \mathrm{Km}$ leste de Alto Paraíso de Goiás, 16-II-1979, fl., F. Cardoso \& M.S.G. Ferreira 66 (UB), ib., ca. $20 \mathrm{Km} \mathrm{W}$ da Chapada dos Veadeiros, 10-II-1966, fl., H.S. Irwin 12526 (UB). Cocalzinho de Goiás, Serra dos Pireneus, estrada para o hotel Fazenda Cabana dos Pireneus, 18-II-2013, Rocha, M.J.R.R. 897 (BHCB). Monte Alegre de Goiás: 12-20 Km de Alto Paraíso de Goiás, 7-II-1981, fl., King, L.R.M \& Bishop, L.E. 8847 (UB). Cocalzinho de Goiás: Serra dos Pireneus, br-070, ca. $20 \mathrm{Km}$ da cidade, 24-IV-2012, fl., R.A. Pacheco et al. 738 (HUFU). Pirenópolis: Parque Estadual da Serra dos Pireneus, 23.III.2003, Miranda et al. 31 (HUEG).

Endêmica do Brasil (Pará, Distrito Federal, Goiás, Mato Grosso do Sul e Minas Gerais), conforme Romero \& Woodgyer (2015). Foi encontrada formando expressivas populações (mais de 30 indivíduos) em cerrado rupestre, campo sujo e úmido, muitas vezes entre gramíneas, entre 1462-1539 m de altitude com flores e frutos em março, julho e agosto.

Diagnosticada pelas partes vegetativas, hipanto e frutos conspicuamente indumentados, os tricomas estrigosos ou seríceos entremeados por glândulas sésseis, flores com pétalas rosas ou brancas, estames conspicuamente dimórficos e anteras discolores. A depender do ambiente, podem apresentar lâminas glabras com glândulas circulares e margem ciliada. Relaciona-se $\operatorname{com} M$. serpyliifolia como já comentado.

18. Microlicia viminalis (DC.) Triana, Trans. Linn. Soc. Bot. 28: 28. 1871.

Figuras 24 m-x, 26 a-e

Subarbustos 0,2-2 m alt., eretos ou decumbentes, cespitosos ou não. Ramos dicotômicos, não corimbiformes, quando adultos, cilíndricos, decorticantes e com evidentes cicatrizes foliares, quando jovens cilíndricos ou subquadrangulares, ambos glabros. Folhas sésseis, imbricadas ou laxamente imbricadas; lâminas 5,2-16 × 1,5-11 mm, ovais ou lanceoladas, coriáceas, base truncada ou subcordada margem ciliada ou ciliado-glandular ao menos no terço superior, ápice agudo e mucronulado ou apiculado, pungente, 3-9-nérvias, glabras ou hirsuto-glandulares, sem glândulas arredondadas. Flores 1,5-2,7 cm compr., solitárias, 5-meras, pedicelo 0,7-5 mm compr.; hipanto 3,2-6 × 2,5-4,8 mm, urceolado, não costado, híspido ou hirsuto-glandular e com dois pares de longos tricomas na base externamente; lacínias do cálice 5-9 × 2,2-3,5 mm, triangulares ou lanceoladas, ciliado-glandulares, cuspidadas ou mucronuladas, semelhantes ao hipanto, glabras ou com mesmo indumento do hipanto internamente; pétalas 11-22 × 7-14 mm, rosa pink ou lilás, obovais, glabras, ápice oblíquomucronado, margem ciliada ou ciliado-glandular ao menos no terço superior; estames 10, dimórficos, os antessépalos com filetes 5-7,2 mm compr., conectivos com 5-9 mm de prolongamento, apêndices 1-2,1 mm compr., anteras 3,3-4,5 × 0,9-1,3 mm, róseas, rostro 0,7-1,5 mm compr.; os antepétalos com filetes 5,2-6,7 mm compr., conectivos com 0,7-1,3 mm de prolongamento, apêndices $0,2-1 \mathrm{~mm}$ compr., anteras 2-4 × 0,8-1,1 mm, amarelas, rostro 0,4-1,1 mm compr., ambos com filetes róseo-amarelados, conectivos róseos, apêndices achatados e inteiros amarelos ou róseo-amarelados, e anteras bi-tetraesporangiadas; ovário 3-3,2 × 2,2-2,5 mm, oblongoide ou elipsoide, 3-locular, estilete 8,2-16 mm compr., róseo. Cápsulas 4-11 $\times$ 3-7 mm, globosas ou urceoladas, marrons ou castanhas. Sementes 1-2,5 $\times 1-2 \mathrm{~mm}$, trapezoidais ou oblongas, beges ou douradas.

Material examinado: Alto Paraíso de Goiás, trilha que leva ao Salto de $80 \mathrm{~m}, 14^{\circ} 10^{\prime} 29^{\prime \prime} \mathrm{S}, 47^{\circ} 48^{\prime} 3,0^{\prime \prime} \mathrm{W}$, 10-IX-1996, fl., R.C. Mendonça et al. 2612 (UFG); proximidades do Morro Peito de Moça, após atravessar o rio Preto, 5-IX-2014, fl., fr., L.S. Inocêncio et al. 98, 99 (UFG); Trilha que leva ao Salto de 80 e 120 m, $14^{\circ} 09^{\prime} 49,8^{\prime \prime} \mathrm{S}, 4^{\circ} 49^{\prime} 55,5^{\prime \prime} \mathrm{W}, 920 \mathrm{~m}, 13-\mathrm{III}-2015$, fr., D.O. Diniz et al. 84 (UFG), ib., 1409'49,9"S, $47^{\circ} 49^{\prime} 55^{\prime \prime} \mathrm{W}, 930 \mathrm{~m}, 2-\mathrm{V}-2015$, fr., D.O. Diniz et al. 236, 238 (UFG); topo do morro do Japonês, $14^{\circ} 02^{\prime} 53,9^{\prime \prime} \mathrm{S}, 47^{\circ} 31^{\prime} 49,6^{\prime \prime} \mathrm{W}, 1534 \mathrm{~m}, 14-\mathrm{III}-2015$,

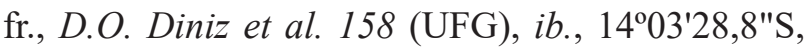
47²3' $8,3^{\prime \prime W}, 1516$ m, 15-III-2015, fr., D.O. Diniz et al. 144 (UFG); Margem esquerda da GO 118/ Alto Paraíso-Teresina, 13ํำ' $2,8^{\prime \prime} \mathrm{S}, 4^{\circ} 30^{\prime} 44,8^{\prime \prime} \mathrm{W}$, 1467 m, 19-IV-2015, fr., D.O. Diniz et al. 170, 171 (UFG); ca. $1 \mathrm{Km}$ a nordeste do alojamento do parque, $14^{\circ} 08^{\prime} 23,2^{\prime \prime} \mathrm{S}, 47^{\circ} 47^{\prime} 22,8^{\prime \prime} \mathrm{W}, 1060 \mathrm{~m}$, 5-VI-2015, D.O. Diniz et al. 402, 403 (UFG); entrada para o Pouso Alto, à $10 \mathrm{~m}$ da cruz, $13^{\circ} 58^{\prime} 23^{\prime \prime} \mathrm{S}, 4^{\circ} 29^{\prime} 48,6^{\prime \prime} \mathrm{W}, 1008 \mathrm{~m}$, 21-VIII-2015, fl., D.O. Diniz et al. 490, 491, 492 (UFG); à 3,5 Km da GO-118, entrada para Pouso Alto, 21-VIII-2015, fl., D.O. Diniz et al. 519, 520,

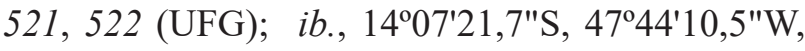
$1203 \mathrm{~m}, 7-\mathrm{X}-2015$, fl, 609, 610 (UFG); estrada que leva às corredeiras, $14^{\circ} 10^{\prime} 22,7^{\prime \prime} \mathrm{S}, 4^{\circ} 49^{\prime} 34,8^{\prime \prime} \mathrm{W}$, $991 \mathrm{~m}, 3-\mathrm{II}-2016,769$ (UFG); trilha para os saltos, 26-II-2016, 1409'58"S, 47049'35"W, 957 m, fr., 


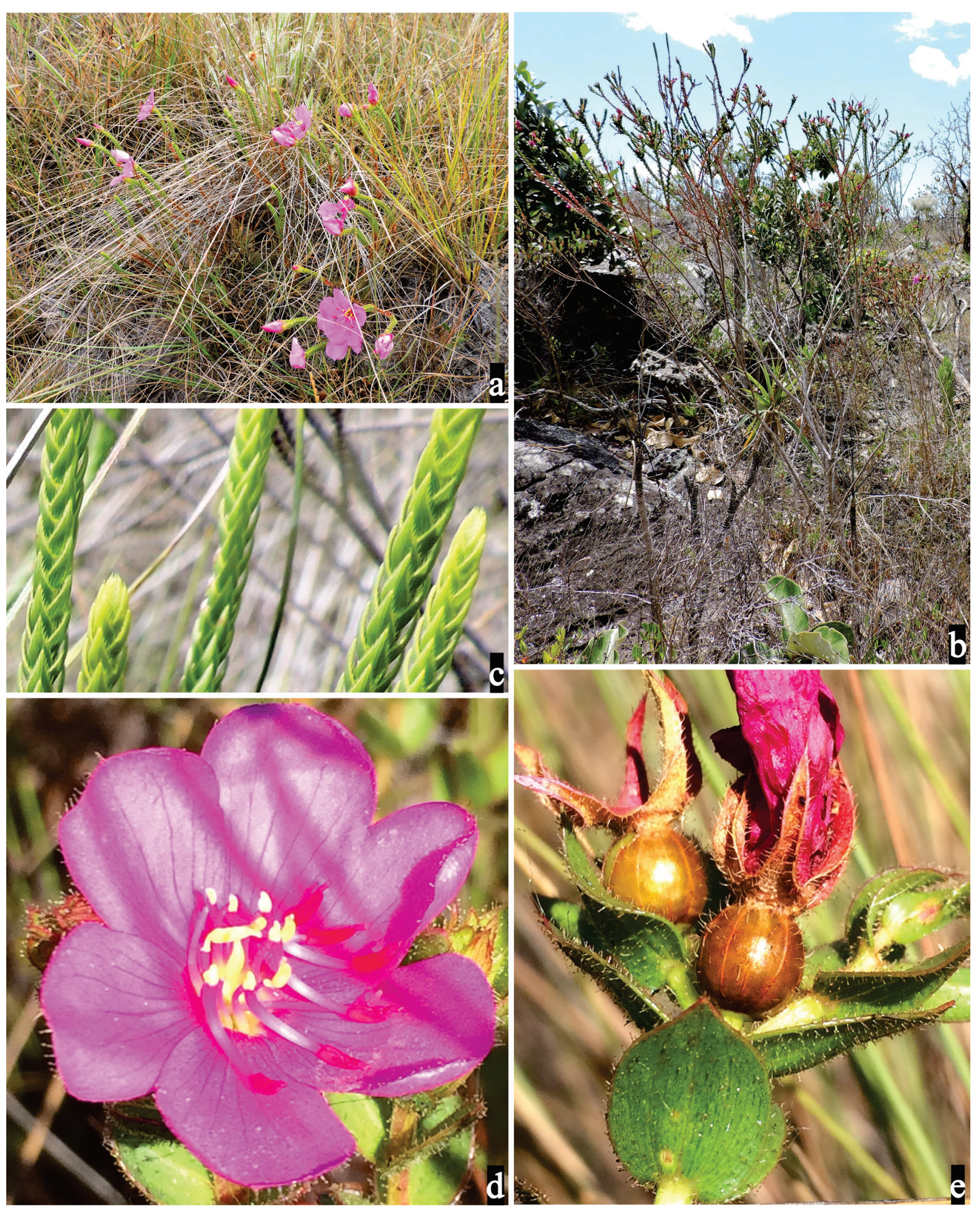

Figura 26. a-e. Microlicia viminalis (DC.) Triana. a. Hábito, subarbusto com ramos decumbentes. b. Hábito, arbusto. c. Ramo folhoso. d. Flor. e. Cápsulas.

Figure 26. a-e. Microlicia viminalis (DC.) Triana. a. Habit, sub-shrub with decumbent branches. b. Habit, shrub. c. Leafy branch. d. Flower. e. Mature Fruit with hypanthium. 
Fontelas, J.C. et al. 129 (HUFU); à $7 \mathrm{Km}$ do morro do Japonês, à $20 \mathrm{Km}$ de Alto Paraíso na GO-118 em sentido Alto Paraíso à Teresina de Goiás, 135ำ $4,8^{\prime \prime} \mathrm{S}$, 47030'32,5"W, 1495 m, 29-VII-2016, fl., D.O. Diniz et al. 944, 952, 973, 988 (UFG); parada à $6 \mathrm{Km}$ de Alto Paraíso de Goiás, $500 \mathrm{~m}$ de dentro do parque, $14^{\circ} 5^{\prime} 12,1^{\prime \prime S}, 47^{\circ} 31^{\prime} 28,4^{\prime \prime} \mathrm{W}, 1366$ m, 19-VIII-2016, fl., D.O. Diniz et al. 1053 (UFG); ib., 14º2'56,5"S, 47038'21,4"W, 1203 m, 19-IX-2015, fl, fr., D.O. Diniz et al. 550, 551, 552, 553, 554, 555, 561, 566 (UFG); final do parque, sentido Teresina de Goiás, ca. $150 \mathrm{~m}$ à partir da estrada, $14^{\circ} 54^{\prime} 54,4^{\prime \prime} \mathrm{S}, 47^{\circ} 25^{\prime} 40,4^{\prime \prime} \mathrm{W}, 1447 \mathrm{~m}$, D.O. Diniz et al. 684, 686 (UFG).

Material examinado adicional: BRASIL. DisTRITo Federal: Brasília, Fazenda Água limpa, 29-VIII-1980, fl., TSMG 2418 (BHCB). Goiás: Alto Paraíso de Goiás: Chapada dos Veadeiros, 14-II-1966, fr., H.S. Irwin et al. 12828 (UB), ib., 5-IX-1972, fl., Rizzo, J.A. 8295 (UFG), ib., 6-VIII-1972, fl., J.A. Rizzo 8244 (UFG), ib., à $5 \mathrm{Km}$ de Alto Paraíso, 25-I-1979, fr., Gates \& Estabrook 57 (UB), ib., estrada para Campos Belos, 15,5 Km N de Alto Paraíso, 29-V-1994, fr., $S$. Splett 280 (UB), ib., Fazenda Água Fria, ca. $10 \mathrm{Km}$ em direção à Terezina de Goiás, 19-VII-2000, C. Munhoz 1767 (HUFU), ib., em Portal da Chapada, 9-VIII-2007, Proença, C. \& Harris, S.A. 3385 (UB), ib., em Portal da Chapada, 6-IX-2008, Miranda, S.C. et al. 1123 (UB). Cavalcante: em campo sujo, VII-2011, fl., fr., J.S. Silva 666 (UB). Cristalina: Serra dos Topázios, $16^{\circ} 45^{\prime} \mathrm{S}, 47^{\circ} 40^{\prime} \mathrm{W}, 19-\mathrm{XI}-1995$, fr., G.L. Moretto et al. 14 (UB), ib., $16^{\circ} 45^{\prime} \mathrm{S}, 47^{\circ} 40^{\prime} \mathrm{W}, 23-\mathrm{II}-1998$, fl., $C$. Proença et al. 1963 (UB). PirenóPolis: Serra dos Pireneus, 18-VIII-1995, fl., M.B. Alcantara 97 (UFG), $i b$., Serra dos Pireneus, 8-VIII-2002, fl., fr., Santos, M.L. 157 (HUEG), ib., Parque Estadual da Serra dos Pireneus, 13-IX-2003, fl., fr., S.C. Miranda et al. 401, 441, 455 (HUEG).

Microlicia viminalis é endêmica do Brasil e encontrada na Bahia, no Distrito Federal, em Goiás e em Minas Gerais (Flora do Brasil 2020). No PNCV foi encontrada em campos úmidos e em campos ou cerrados rupestres com flores e frutos em agosto e outubro e frutos também entre fevereiro e maio e no mês de julho e novembro.

Há dois morfotipos de Microlicia viminalis na área estudada, os quais foram subordinados por Romero (2003) para esta espécie. Um deles reúne subarbustos com $26-90 \mathrm{~cm}$ alt., comumente cespitosos com lâminas 5,2-10,1 × 1,5-3,5 mm, glabras, imbricadas, ovais ou lanceoladas de base semiamplexicaule, margem ciliada e ápice agudo e mucronulado ou apiculado, e flores com pedicelo 0,7-1 mm compr.; o outro subarbustos decumbentes ou arbustos entre $0,6-2 \mathrm{~m}$ alt., não cespitosos, lâminas 6,5-16 × 5,5-11 mm, híspido-glandulares em ambas as faces, laxamente imbricadas, ovais ou largamente elípticas de base truncada ou subcordada, margem ciliado-glandular, ápice agudo com tricoma hirsutoglandulares; flores com pedicelo 1-5 mm compr. $M$. viminalis é diferenciada das demais estudadas pelas folhas coriáceas, sem glândulas e com ápice pungente o que lhe torna semelhante a plantas do gênero Chaetostoma. Porém Microlicia viminalis não possui uma coroa de tricomas no ápice do hipanto, característica típica das espécies de Chaetostoma, e se relaciona morfologicamente com $M$. melanostagma conforme exposto na descrição da mesma.

\section{Agradecimentos}

Os autores agradecem à Fundação de Amparo à Pesquisa do Estado de Goiás (FAPEG), (Processo 201510267000 650) e ao Conselho Nacional de Desenvolvimento Científico e Tecnológico (CNPq), pelo apoio financeiro (Processo $n^{\circ} .307371 / 2013-1$ ); ao desenhista Cristiano Gualberto, pelas ilustrações; aos Curadores de Herbários, pelos empréstimos das coleções, em especial o apoio do Herbário UFG/ PRPI; ao Sistema de Autorização e Informação em Biodiversidade/Instituto Brasileiro do Meio Ambiente e dos Recursos Naturais Renováveis (SISBIO/ IBAMA), pela permissão de coleta na área de estudo.

\section{Literatura citada}

Almeda, F. \& A. B. Martins. 2001. New combinations and new names in some Brazilian Microlicieae (Melastomataceae), with notes on the delimitation of Lavoisiera, Microlicia, and Trembleya. Novon 11: 1-7.

Brasil. Ministério de Minas e Energia. 1982. Folha SD 23 Brasília: geologia, geomorfologia, pedologia, vegetação e uso potencial da terra / Projeto Radambrasil. O Projeto, Rio de Janeiro. 655p.

BFG (The Brazil Flora Group). 2015. Growing knowledge: an overview of Seed Plant diversity in Brazil. Rodriguésia, v.66, n.4, pp. 1085-1113.

Brummit, R.K. \& Powell, C.E. 1992. Authors of Plant Names. Royal Botanic Gardens, Kew.

Clausing, G. \& Renner, S.S. 2001. Molecular phylogenetics of Melastomataceae and Memecylaceae: implications for character evolution. American Journal of Botany 88: 486-498. 
Cogniaux, A. 1891. Melastomataceaes. In: A. Candolle \& C. Candolle (eds.). Monographiae phanerogamarum, v. 7, G. Masson, Paris.

Diniz-Neres, D.O. \& Silva, M.J. 2017. A remarkable new species of Microlicia (Melastomataceae) including an identification key to species of the genus from the Chapada dos Veadeiros National Park, Goiás, Brazil. Systematic Botany 42: 554-561.

Diniz-Neres, D.O. \& Silva, M.J. 2018. Microlicia veadeirana (Melastomataceae, Microlicieae), a new species from the Chapada dos Veadeiros National Park, Brazil. Brittonia 70: 84-89.

Diniz-Neres, D.O. \& Silva, M.J. 2017. A remarkable new species of Microlicia (Melastomataceae) including an identification key to species of the genus from the Chapada dos Veadeiros National Park, Goiás, Brazil. Systematic Botany 42: 554-561.

Diniz-Neres, D.O. \& Silva, M.J. 2018. Microlicia veadeirana (Melastomataceae, Microlicieae), a new species from the Chapada dos Veadeiros National Park, Brazil. Brittonia 70: 84-89.

Diniz-Neres, D.O. \& Silva, M.J. 2017. A remarkable new species of Microlicia (Melastomataceae) including an identification key to species of the genus from the Chapada dos Veadeiros National Park, Goiás, Brazil. Systematic Botany 42: 554-561.

Diniz-Neres, D.O. \& Silva, M.J. 2018. Microlicia veadeirana (Melastomataceae, Microlicieae), a new species from the Chapada dos Veadeiros National Park, Brazil. Brittonia 70: 84-89.

Diniz-Neres, D.O. \& Silva, M.J. 2017. A remarkable new species of Microlicia (Melastomataceae) including an identification key to species of the genus from the Chapada dos Veadeiros National Park, Goiás, Brazil. Systematic Botany 42: 554-561.

Diniz-Neres, D.O. \& Silva, M.J. 2018. Microlicia veadeirana (Melastomataceae, Microlicieae), a new species from the Chapada dos Veadeiros National Park, Brazil. Brittonia 70: 84-89.

Diniz-Neres, D.O. \& Silva, M.J. 2017. A remarkable new species of Microlicia (Melastomataceae) including an identification key to species of the genus from the Chapada dos Veadeiros National Park, Goiás, Brazil. Systematic Botany 42: 554-561.

Diniz-Neres, D.O. \& Silva, M.J. 2018. Microlicia veadeirana (Melastomataceae, Microlicieae), a new species from the Chapada dos Veadeiros National Park, Brazil. Brittonia 70: 84-89.

Diniz-Neres, D.O. \& Silva, M.J. 2017. A remarkable new species of Microlicia (Melastomataceae) including an identification key to species of the genus from the Chapada dos Veadeiros National Park, Goiás, Brazil. Systematic Botany 42: 554-561.
Diniz-Neres, D.O. \& Silva, M.J. 2018. Microlicia veadeirana (Melastomataceae, Microlicieae), a new species from the Chapada dos Veadeiros National Park, Brazil. Brittonia 70: 84-89.

Diniz-Neres, D.O. \& Silva, M.J. 2017 A remarkable new species of Microlicia (Melastomataceae) including an identification key to species of the genus from the Chapada dos Veadeiros National Park, Goiás, Brazil. Systematic Botany 42: 554-561.

Diniz-Neres, D.O. \& Silva, M.J. 2018. Microlicia veadeirana (Melastomataceae, Microlicieae), a new species from the Chapada dos Veadeiros National Park, Brazil. Brittonia 70: 84-89.

Diniz, D.O.\& M.J. Silva. 2018. A noteworthy new species of Microlicia (Melastomataceae, Microlicieae) from the highlands of the state of Goiás, Brazil. Journal of the Torrey Botanical Society 145:175-181.

Fritsch, P.W., Almeda, F., Renner, S.S., Martins, A.B., \& Cruz, B.C. 2004. Phylogeny and circumscription of the near-endemic Brazilian tribe Microlicieae (Melastomataceae). American Journal of Botany 91: 1105-1114.

Flora do Brasil. 2020. Jardim Botânico do Rio de Janeiro. Disponível em http://floradobrasil.jbrj.gov.br/ (acesso em 27-VI-2019).

Goldenberg, R., Baumgratz, J.F.A., \& Souza, M.L.D.E.R. 2012. Taxonomia de Melastomataceae no Brasil: retrospectiva, perspectivas e chave de identificação para os gêneros. Rodriguésia 63: 145-161.

Goldenberg, R., Bacci, L.F., \& Moraes, J.W. 2015. A tribo Microlicieae (Melastomataceae) no estado do Paraná. Rodriguesia 66: 155-165.

Harris, G.J. \& Harris, M.W. 1997. Plant identification terminology: an illustrated glossary. Spring Lake, Payson.

QGIS (Quantum GIS Development Team). 2015. Quantum GIS Geographic Information System. Version 2.8.2.

Mori, S.A, Silva, L.A, Lisboa, G. \& Coradin, L. 1989. Manual de Manejo do Herbário Fanerogâmico. Centro de Pesquisa do cacau, Ilhéus, Bahia.

Penneys, D.S., Michelangeli, F.A., Judd, W.S. \& Almeda, F. 2010. Henrietteeae (Melastomataceae): a new neotropical berry-fruited tribe. Systematic Botany 35: 783-800.

Radford, A.E, Dickison, W.C, Massey, J.R., Bell, C.R. 1974. Vascular Plant Systematics. Harper \& Row Publishers, New York.

Renner, S.S. 1993. Phylogeny and classification of the Melastomataceae and Memecylaceae. Nordic Journal of Botany 13: 519-540.

Rocha, M.J.R., Guimarães, P.J.F., Michelangeli, F.A., Romero, R. 2016. Phylogenetic placement and a new circumscription of Poteranthera (Microlicieae; Melastomataceae). Phytotaxa 263: 219-232. 
Romero, R. 2003. Revisão taxonômica de Microlicia sect. Chaetostomoides (Melastomataceae). Revista Brasileira de Botânica 26: 429-435.

Romero, R. Versiane, A.F.A., Fontelas, J.C., DinizNeres, D.O., de Paula, O.C. 2017. A New Species of Microlicia (Melastomataceae) with Bright Golden Cuticle from Chapada dos Veadeiros, Goiás (Central Brazil), Systematic Botany 42: 562-568.

Romero, R.,Woodgyer, E. 2015. Microlicia in Lista de Espécies da Flora do Brasil. Jardim Botânico do Rio de Janeiro. Disponivel em http://floradobrasil.jbrj.gov.br/ jabot/floradobrasil/FB30787 (acesso em 11-IX-2019).

Stafleu, F.A. \& Cowan, R.S. 1976. Taxonomic literature. A selective guide to Botanical publications and collections with dates, commentaries and types. Regnum Vegetabile 94: 1-1136.
Stevens, P.F. 2016. Angiosperm Phylogeny Website. Version 12, July 2012 [and more or less continuously updated since]. Disponível em http://www.mobot. org/MOBOT/research/APweb/ (acesso em 17-VII2016).

Thiers, B. 2019. Index Herbariorum: A global directory of public herbaria and associated staff. New York Botanical Garden's Virtual Herbarium, New York. Disponível em http://sweetgum.nybg.org/ih/ (acesso em 15-II-2019).

Triana, J.J. 1871. Les Mélastomatacées. Transactions of the Linnean Society of London 28: 1-188.

Wurdack. 1993. Ossaea. In: A.R.A. Górts-Van Rijn (ed.). Flora of the Guianas. Koenigstein, Koeltz Scientific Books, pp. 265-268. 